\title{
Funcionalidade e sazonalidade sobre Cerrado e sobre ecótono Floresta-Cerrado: uma investigação com dados micrometeorológicos de energia e $\mathrm{CO}_{2}$
}

\author{
RAFAEL NORA TANNUS
}

Dissertação apresentada à Escola Superior de Agricultura “Luiz de Queiroz”, Universidade de São Paulo, para a obtenção do título de Mestre em Ecologia de Agroecossistemas.

\author{
PIRACICABA \\ Estado de São Paulo - Brasil
}

Novembro - 2004 


\title{
Funcionalidade e sazonalidade sobre Cerrado e sobre ecótono Floresta-Cerrado: uma investigação com dados micrometeorológicos de energia e $\mathrm{CO}_{2}$
}

\author{
RAFAEL NORA TANNUS
}

Biólogo

Orientadora:Prof. Dr. HUMBERTo RIBEIRO DA ROCHA

Dissertação apresentada à Escola Superior de Agricultura "Luiz de Queiroz", Universidade de São Paulo, para a obtenção do título de Mestre em Ecologia de Agroecossistemas.

PIRACICABA

Estado de São Paulo - Brasil

Novembro - 2004 
Dados Internacionais de Catalogação na Publicação (CIP) DIVISÃO DE BIBLIOTECA E DOCUMENTAÇÃO - ESALQ/USP

Tannus, Rafael Nora

Funcionalidade e sazonalidade sobre cerrado e sobre ecótono floresta-cerrado: uma investigação com dados micrometeorológicos de energia e $\mathrm{CO}_{2} /$ Rafael Nora Tannus. - Piracicaba, 2004.

92 p. : il.

Dissertação (Mestrado) - - Escola Superior de Agricultura Luiz de Queiroz, 2004. Bibliografia.

1. Cerrado 2. Ciclo de carbono 3. Ecologia de comunidade 4.Ecossistema 5. Estresse 6. Floresta 7. Micrometeorologia 8. Produtividade florestal 9. Umidade do solo 10. Variação sazonal I. Título

CDD 574.5247

"Permitida a cópia total ou parcial deste documento, desde que citada a fonte - $\mathrm{O}$ autor" 
Dedico este trabalho

Ao meus avós, que incentivaram sem precisar compreender

A minha irmã, que por tantas vezes tentou incutir a beleza nos meus olhos

Aos meus pais, que incentivaram, sustentaram, acreditaram e não me deixaram desistir

Ofereço a mémoria

Do Professor Doutor Antonio Sergio Ditadi ( in memorian) que me guiou na escuridão da minha alma

Do meu irmão Sullivan Klay Galvão Borges (in memoriam) que me ensinou que coragem é uma coisa que se escolhe ter. 


\section{Agradecimentos}

Realizar este trabalho não seria possível sem a ajuda e o apoio de muitas pessoas. De forma concisa, agradeço todas as pessoas que de alguma forma me ensinaram alguma coisa ou me incentivaram de alguma maneira. Porém, algumas pessoas tiveram um papel central tanto na minha vida, quanto no trabalho e a estas eu gostaria de fazer um agradecimento especial.

Agradeço a Universidade de São Paulo por tudo o que me permitiu viver e pelo apoio institucional. A FUSP pela bolsa concedida. O CNPQ pela bolsa e por ter financiado o experimento do TO. A FAPESP por ter financiado o experimento de SP. Aos funcionários e professores da ESALQ e do CENA que, apesar do pouco contato, sempre se mostraram profissionais e receptivos.

Aos funcionários, amigos e professores do IAG por todos os ensinamentos desde a minha iniciação científica. Em especial, aos funcionários Marisa Maiello, Fagner Gonzalvez, e a Marcia Arakawa por toda ajuda, muito acima das suas obrigações. Aos amigos Pedro "Linha" Lopes, Marcelo Bianchi, Edmilson Freitas e Demerval Soarez e a todo pessoal do laboratório Master por toda a ajuda ao longo destes anos. Aos professores Pedro e Maria Assunção da Silva Dias por todos os ensinamentos $e$ oportunidades de aprender meteorologia. Não poderia deixar de agradecer, ao pessoal da portaria do IAG pelo companherismo e pelo altruístico café nas madrugadas que eu passei no laboratório. Esta lição não será esquecida.

A prof. Dra. Tsai SuiMui pela ajuda com as minhas dificuldades burocráticas e pelo apoio como coordenadora do programa de pós-graduação

Aos professores Prof. Dr. Waldir Mantovan, Prof. Dr. Michael Keller, Prof. Dr. Jean Paul Metgzer, Prof. Dr. Leopoldo Magno Coutinho, Prof. Dr. Marcos Buckerige, 
Prof. Dr. Marcos Aidar, Prof. Dr. Alex Krusche e a Dra. Luciana Alves por todas as conversas, artigos, e questionamentos que me ilumiram não apenas o caminho, mas também o espírto.

Aos meus amigos e colegas do Laboratório de Clima e Biosfera: Leandro Pinto, Rogério Bruno, Ricardo Acosta, Jonathan Dupont, Leuda Olivera, Fabricio Zanchi e Robinson Juarez por toda a ajuda e pela compreensão com um biólogo no meio de um mar de "caras da exatas".

Devo muito, não apenas como aluno, mas como pessoa ao Prof. Dr. Reynaldo Victoria e a Prof. Dra. Maria Victória Ballester pela ajuda, carinho, compreensão e por todo o aprendizado. Sem a sua ajuda não seria possíve o término do Mestrado.

Ao Prof. Dr. Humberto Ribeiro da Rocha, "o seu Rocha", pela paciência, amizade, por não ter "me chutado" de sua sala enquanto ouvia minhas idéias mirabolantes, por ter me ensinado a programar, a escrever e a me virar. Agradeço ele também por ter ensinado que a vida acadêmica pode ser uma coisa emocionante, principalmente em relação ao cumprimento de prazos. Sou igualmente grato, pela coragem de aceitar um aluno como eu.

A Msc. Helber "minha-mãe-judia" Custódio de Freitas, pelo profissionalismo, assistência, amizade e por me incentivar, de forma veemente, a dormir cedo, acordar cedo, almoçar, beber e fumar menos, comer direito, perder peso, arrumar uma boa moça, etc, etc. Só sobrevivi ao mestrado, pois tive está nobre compania ao meu lado por todo o caminho

Aos meus amigos e amigas, irmão e irmãs, perenes e efemeros, atuais $e$ passados, grandes ou pequenos, fortes ou fracos, os que ajudaram diretamente e os que não, os verdadeiros. A todos estes, muito obrigado. Em especial, a Daniel Victoria, Daniel Tannus, Aline Reydon, Fabiano Sannino, Wilson Tamega Jr, Renato Golin, João Atui e Alexandre Sotero pela grande a ajuda neste trabalho.

Acima de todos, agradeço a minha família, como um todo. Com o seu incansável apoio, infinita compreensão, inacreditável capacidade de crítica e constantes lições de vida (e isto inclui até o meu tio Malufista). 
"Eu queria ter um cérebro" - O espantalho, em “O Mágico de Oz”

"Bom humor é sinal de inteligência" - Albert Einstein

Em 480 a.c. Xerxes, o imperador Persa, com um exército de 200 mil homens, iniciou a invasão da Grécia. Leônidas, rei Espartano, foi proibido pelo Conselho dos Anciãos de ir à guerra. Então, reuniu a sua guarda pessoal de $\mathbf{3 0 0}$ homens e marchou para o Norte, até uma pequena passagem entre as montanhas, chamada de Termópilas.

Antes da batalha, um mensageiro disse :

- Vocês devem desistir ! O exército persa é tão numeroso que quando atacarem, as fechas cobrirão o sol !

Dioneceu, um dos Espartanos, respondeu :

- Tanto melhor, lutaremos a sombra! 


\section{SUMÁRIO}

Página

LISTA DE FIGURAS .................................................................... ix

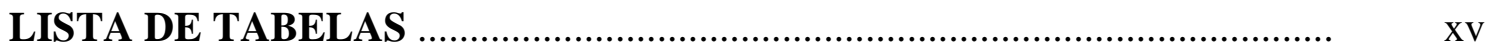

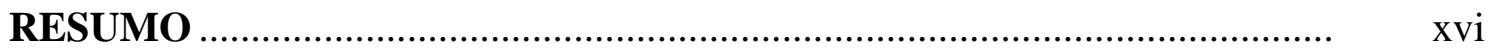

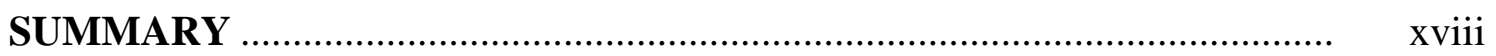

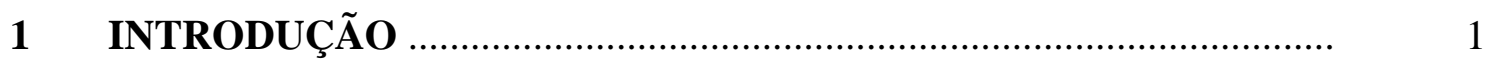

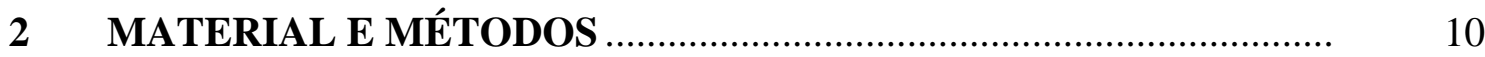

2.1 Cálculo de Umidade Volumétrica...................................................... 10

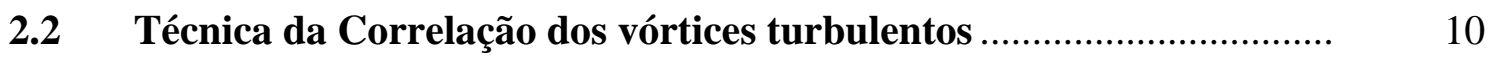

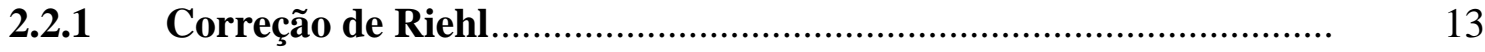

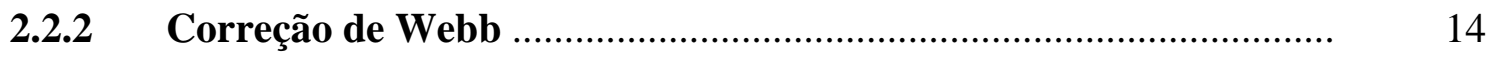

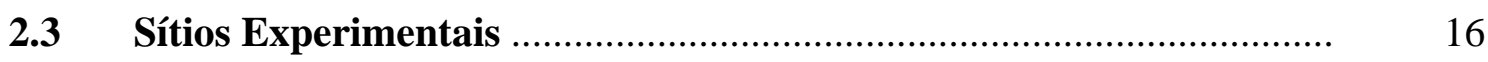

2.3.1 Sítio Experimental ecótono Floresta-Cerrado.................................... 17

2.3.2 Sítio Experimental do Cerrado Sensu stricto (s.s.) ........................... 21

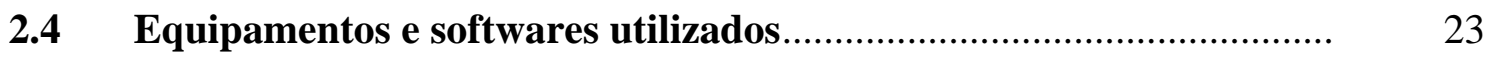

$2.5 \quad$ Indíces de Funcionalidade ................................................................... 24

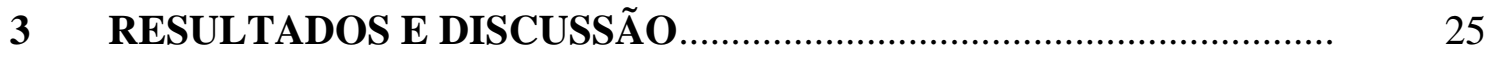

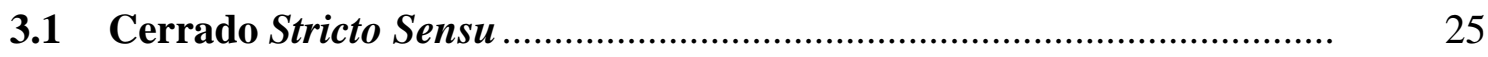

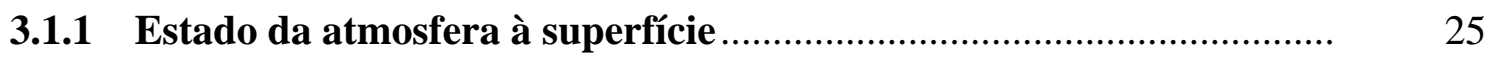

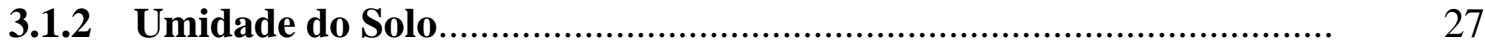

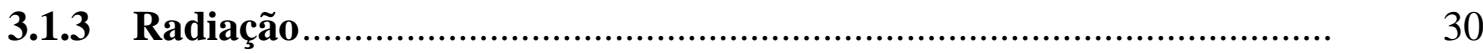


3.1.4 Fluxos de superfície......................................................................

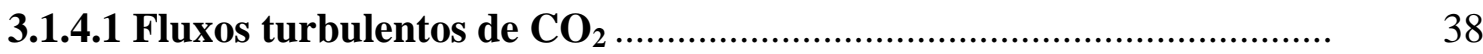

3.2 Ecótono Floresta-Cerrado _.......................................................... 41

3.2.1 Tolerância à Inundação ................................................................... 43

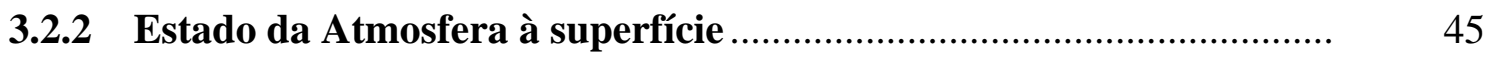

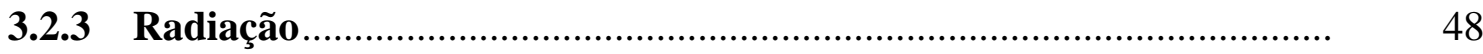

3.2.4 Processos no solo ..........................................................................

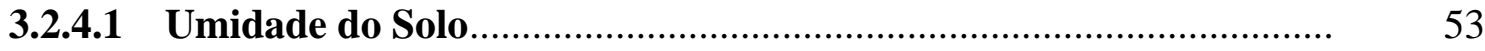

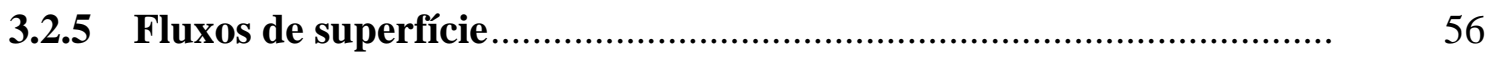

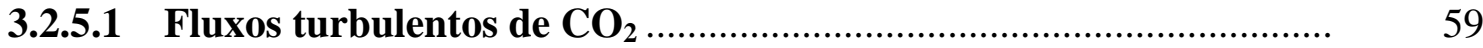

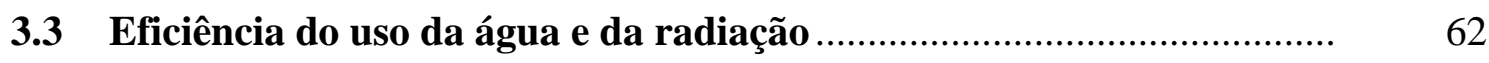

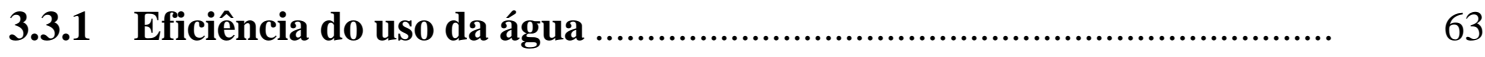

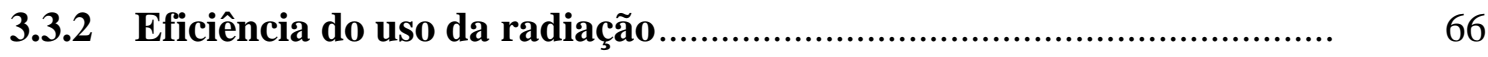

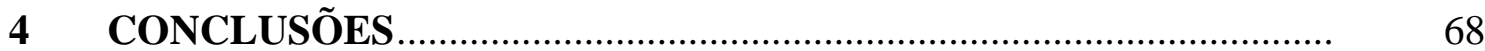

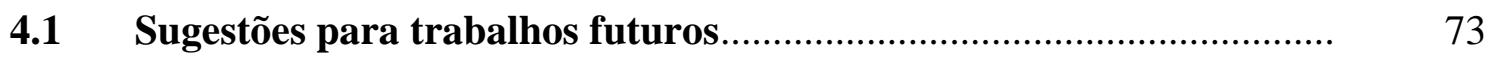

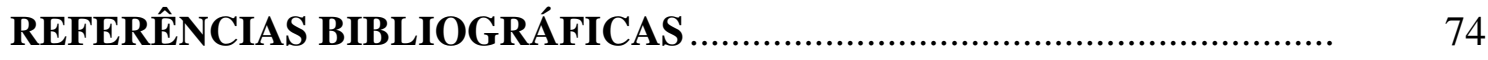

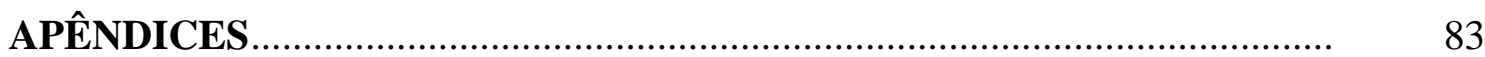




\section{LISTA DE FIGURAS}

Página

1 Distribuição dos Biomas no Brasil. (Ribeiro \& Walter 1998) ..................... 5

2 Recorte do mapa da vegetação do Brasil (IBGE 2004). As cores verdes e esverdeadas indicam locais com floresta ombrófila densa. As cores amarelo e amareladas indicam áreas de Cerrado. As cores cinzas indicam áreas de tensão ecológica. O círculo preto indica a localização aproximada do sítio experimental

3 Imagem de satélite mostrando a área. O ponto colorido indica a posição da torre. O ponto branco a Ilha do Bananal

4 Imagem em detalhe. $\mathrm{O}$ rio de maior porte na Figura é o Rio Araguaia. O ponto colorido indica a posição da torre..................................

5 Foto aérea do sítio experimental do ecótono Floresta-Cerrado com a delimitação aproximada dos biomas. Fotografia aérea : Humberto

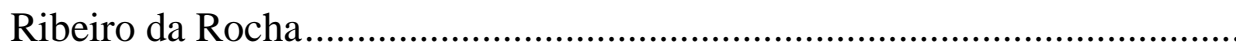

6 Desenho esquemático da estação durante a fase seca. Desenho :

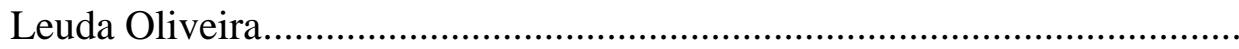

7 Desenho esquemático da estação durante o período de inundação. Desenho: Leuda Oliveira

8 Distruição das fisionomias na Gleba Pé-de-Gigante, do Parque Estadual de Vassununga. Fonte: Batalha (1997)

9 Precipitação acumulada diária no período de 2001(a); 2002(b) e 2003(c), em mm, no Cerrado s.s 
10 Média móvel diária observada no Cerrado s.s para: Temperatura média do ar, em ${ }^{\circ} \mathrm{C}$ (linha preta) para o ano de 2001 (a), 2002 (c) e 2003 (e); e Umidade relativa, em \% (linhas vermelhas), para os anos de 2001(b), 2002(d) e 2003 (f) ................................................................... 27

11 Precipitação acumulada diária, em mm, superior; e umidade volumétrica até $240 \mathrm{~cm}$ de profundidade, do Cerrado Seco, em $\mathrm{m}^{3} \mathrm{~m}^{-}$ 3 , para o ano de 2001. Fonte: Bruno (2004)

12 Precipitação acumulada diária, em mm, superior; e umidade volumétrica até $240 \mathrm{~cm}$ de profundidade, do Cerrado Seco, em $\mathrm{m}^{3}$ $\mathrm{m}^{-3}$, para o ano de 2002. Fonte: Bruno (2004)

13 Média (móvel) diária da irradiância PAR incidente no Cerrado s.s., para o período de 2001, 2002 e 2003, em $\mu \mathrm{mol}$ PAR m $\mathrm{m}^{-2}$.

14 Médias (móveis) diárias do Albedo-PAR para o Cerrado s.s. ao longo dos anos: 2001, em preto; 2002, em vermelho; 2003, em azul..........

15 Precipitação diária (a) e médias diárias do Albedo-PAR (b), ao longo dos anos de 2001, 2002 e 2003. Para o sítio experimental do Cerrado S.S

16 Fluxos de energia e partição de energia para o Cerrado s.s. para o período de 2001 e 2002: (a) Média diária de Razão de Bowen; Média móvel diária do Fluxo de Calor sensível (c), (linha vermelha); e Fluxo de calor Latente (b) (linha azul), em $\mathrm{W} \mathrm{m}^{-2}$.

17 Médias diárias de Fluxo de $\mathrm{CO}_{2}$, em $\mu \mathrm{mol} \mathrm{CO}_{2} \mathrm{~m}^{-2} \mathrm{~s}^{-1}$, para os anos de 2001 e 2002. (a) Fluxo total (linha preta) ; (b) Fluxo noturno (linha azul) ; (c) Fluxo diurno (linha vermelha); (d) Radiação PAR inicidente. Para o sítio experimental do Cerrado s.s. ...................................

18 Média (móvel) diária para o fluxo de $\mathrm{CO}_{2}$ em $\mu \mathrm{mol} \mathrm{CO}_{2} \mathrm{~m}^{-2} \mathrm{~s}^{-1}$, para o ano de 2001, (linha preta); e para o ano de 2002 (linha vermelha), no sítio experimental do Cerrado s.s....................................... 
19 Interpolação da temperatura, em ${ }^{\circ} \mathrm{C}$, medida com um perfil de 09 termopares na base da torre do ecótono Floresta-Cerrado, durante o período de 21 de março a 30 de maio de 2004 ............................................

20 Precipitação para o período de outubro de 2003 a setembro de 2004, para a área de ecótono. (a) Precipitação acumulada, em mm; (b) Precipitação diária, em mm. As barras verticais indicam o provável início e fim da inundação, respectivamente.

21 Período de outubro de 2003 a setembro de 2004, na área de ecótono Floresta-Cerrado. (a) Precipitação diária, em mm; Média móvel diária de (b) temperatura do ar, em ${ }^{\circ} \mathrm{C}$, (linha vermelha); (c) umidade do ar (linha azul). A barra vertical preta denota o provável inicio da inundação. A barra vermelha aponta para o provável fim da inundação

22 Médias de 15 minutos para o período de outubro de 2003 a setembro de 2004, no ecótono Floresta-Cerrado de : (a) Velocidade do vento, em m/s ; (b) pressão de vapor d’água, em KPa. As barras verticais indicam o provável início e fim da inundação, respectivamente.

23 Média diária de (a) Irradiância PAR incidente, em $\mu \mathrm{mol} \mathrm{m} \mathrm{m}^{-2} \mathrm{~s}^{-1}$; (b) Irradiância solar global refletida (linha preta), em $\mathrm{Wm}^{-2}$; (c)

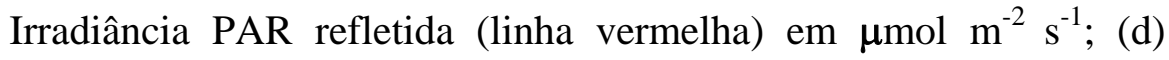
Saldo de radiação, em $\mathrm{Wm}^{-2}$, no período de outubro de 2003 a setembro de 2004, para o sítio do ecótono Floresta-Cerrado. A barra vertical preta denota o provável inicio da inundação. A barra vermelha aponta para o provável fim da inundação.....................................

24 Albedo-PAR médio diário para o período de outubro de 2003 a setembro de 2004. Para o sítio do ecótono Floresta-Cerrado. As barras verticais indicam o provável início e fim da inundação, respectivamente. 
25 Médias diárias da umidade volumétrica em 6 níveis para o período de outubro de 2003 a setembro de 2004. Para o sítio do ecótono Floresta-Cerrado. A barra vertical preta denota o provável inicio da inundação. A barra vermelha aponta para o provável fim da inundação. A barra horizontal vermelha indica ausência de dados (A.D.)

26 Média diáriade concentração de $\mathrm{CO}_{2}$, em ppm, para o período de outubro de 2003 a setembro de 2004, no sítio do ecótono FlorestaCerrado. As barras verticais indicam o provável início e fim da inundação, respectivamente.

27 Média diária de (a) razão de Bowen; (b) Fluxo de calor latente, em $\mathrm{W} \mathrm{m} \mathrm{m}^{-2}$; (c) Fluxo de calor sensível, em $\mathrm{W} \mathrm{m}^{-2}$, para o período de outubro de 2003 a setembro de 2004, no sítio do ecótono FlorestaCerrado. A barra vertical preta indica o provável inicio da inundação. A barra vermelha indica para o provável fim da inundação

28 Média móvel diária de (a) Fluxo de $\mathrm{CO}_{2}$ total; (b) Fluxo de $\mathrm{CO}_{2}$ noturno; (c) Fluxo de $\mathrm{CO}_{2}$ diurno; (d) Irradiância PAR incidente, em $\mu \mathrm{mol} \mathrm{CO}_{2} \mathrm{~m}^{-2} \mathrm{~s}^{-1}$, para o período de outubro de 2003 a setembro de 2004 para o sítio do ecótono Floresta-Cerrado. A barra vertical preta indica o provável inicio da inundação. A barra vermelha indica para o provável fim da inundação

29 Média diária da Eficiência de uso da água (WUE), em $\mathrm{mgCO}_{2}$ (g $\left.\mathrm{H}_{2} \mathrm{O}\right)^{-1}$, para o período de outubro de 2003 a junho de 2004, no sítio do ecótono Floresta-Cerrado. As barras verticais indicam o provável início e fim da inundação, respectivamente.

30 Média (móvel) diária da Eficiência de uso da água (WUE), em $\mathrm{mgCO}_{2}\left(\mathrm{~g} \mathrm{H}_{2} \mathrm{O}\right)^{-1}$, para os anos de 2001, linha preta, e 2002, linha vermelha, no sítio do Cerrado seco 
31 Média diária da eficiência do uso da Radiação (RUE), para o período de outubro de 2003 a setembro de 2004, no ecótono FlorestaCerrado, em $\mu \mathrm{mol} \mathrm{m} \mathrm{m}^{-2}$ de $\mathrm{CO}_{2}\left(\mu \mathrm{mol} \text { PAR m} \mathrm{m}^{-2} \mathrm{~s}^{-1}\right)^{-1}$. As barras verticais indicam o provável início e fim da inundação, respectivamente

32 Médias (móveis) diárias da eficiência do uso da Radiação (RUE), para os anos de 2001, linha preta, e 2002, linha vermelha, para o sítio do Cerrado seco, em $\mu \mathrm{molCO}_{2} \mathrm{~m}^{-2} \mathrm{~s}^{-1}\left(\mu \mathrm{mol} \text { PAR m}{ }^{-2} \mathrm{~s}^{-1}\right)^{-1}$

33 Apêndice 1 - Fluxo de Calor sensível com a correção de Riehl versus Fluxo de Calor sensível sem a correção de Riehl, em $\mathrm{Wm}^{-2}$. Sítio do ecótono Floresta-Cerrado

34 Apêndice 1 - Fluxo de calor latente com a correção de Webb versus Fluxo de calor latente sem a correção de Webb. Para o sítio do ecótono Floresta-Cerrado

35 Apêndice 1 - Fluxo de $\mathrm{CO}_{2}$ corrigido versus fluxo de $\mathrm{CO}_{2}$ sem correção. Ambos em $\mu \mathrm{mol} \mathrm{CO}_{2} \mathrm{~m}^{-2} \mathrm{~s}^{-1}$. Para o sítio do ecótono Floresta-Cerrado

36 Apêndice 2 - Fechamento do balanço de energia para o sítio do ecótono Floresta-Cerrado, para o período de outubro de 2003 a setembro de 2004. Os pontos pretos eferem-se aos fluxos sem correções. Os pontos vermelhos vermelhos referem-se aos fluxos com a correção de Riehl e Webb

37 Apêndice 2 - Fechamento do balanço de energia para o sítio do ecótono Floresta-Cerrado, para o período de outubro de 2003 a janeiro de 2004. Período Pré-alagamento. Os pontos pretos eferemse aos fluxos sem correções. Os pontos vermelhos vermelhos referem-se aos fluxos com a correção de Riehl e Webb 
38 Apêndice 2 - Fechamento do balanço de energia para o sítio do ecótono Floresta-Cerrado, para o período de feveiro de 2004 a junho de 2004. Período de alagamento. Os pontos pretos eferem-se aos fluxos sem correções. Os pontos vermelhos vermelhos referem-se aos fluxos com a correção de Riehl e Webb .................................................

39 Apêndice 2 - Fechamento do balanço de energia para o sítio do ecótono Floresta-Cerrado, para o período de julho de 2004 a setembro de 2004. Os pontos pretos eferem-se aos fluxos sem correções. Os pontos vermelhos vermelhos referem-se aos fluxos com a correção de Riehl e Webb

40 Apêndice 3 - omatória, dos anos de 2001 a 2003, dos valores de radiação incidente obtidos pelo piranômetro (calibrado), em $\mathrm{Wm}^{-2}$, contra somatória do sensor de radiação PAR incidente (não calibrado), em $\mu \mathrm{mol} \mathrm{m} \mathrm{m}^{-2} \mathrm{~s}^{-1}$. Para o sítio experimental do Cerrado .....

41 Apêndice 3 - Somatória, dos anos de 2001 a 2003, dos valores de radiação refletida obtidos pelo piranômetro (calibrado), em $\mathrm{Wm}^{-2}$, contra somatória do sensor de radiação PAR refletida (não calibrado), em $\mu \mathrm{mol} \mathrm{m} \mathrm{m}^{-2} \mathrm{~s}^{-1}$. Para o sítio experimental do Cerrado

42 Apêndice 4 - Velocidade de atrito para o sítio experimental do ecótono Floresta-Cerrado. As barras verticais segmentadas, indicam início e fim aproximado da inundação, respectivamente.

43 Apêndice 4 - Anemogramas do ecótono Floresta-Cerrado. Para todo o período de outubro de 2003 a setembro de 2004. Anemograma de direção do vento (a) média diária, (b) diurno e (c) noturno. A direção do vento só foi contabilizada pra valores do módulo acima de $2 \mathrm{~m} \mathrm{~s}^{-}$

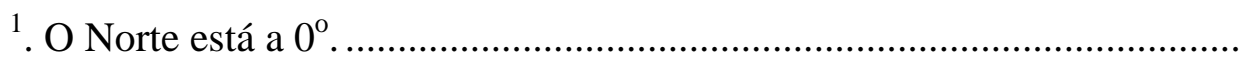




\section{LISTA DE TABELAS}

Página

1 Sensores usados em cada um dos sítios experimentais .............................. 23

2 Albedo-PAR mínimo no trimestre chuvoso Jan-Mar, máximo no trimestre Jul-Set, e médio anual. Número de eventos frios correspondem ao número de dias com temperatura mínima do ar (medida a $22 \mathrm{~m}$ de altura) abaixo de $11^{\circ} \mathrm{C}$, para os anos de 2001, 2002 e 2003, no Cerrado s.s........................................................................... 


\title{
Funcionalidade e sazonalidade sobre Cerrado e sobre ecótono Floresta-Cerrado: uma investigação com dados micrometeorológicos de energia e $\mathrm{CO}_{2}$
}

\author{
Autor: RAFAEL NORA TANNUS \\ Orientador: Prof. Dr. HUMBERTO RIBEIRO DA ROCHA
}

\section{RESUMO}

Este trabalho discute a variabilidade dos fluxos de energia à superfície e de $\mathrm{CO}_{2}$ sobre uma área de Cerrado Sensu stricto no interior de São Paulo, e de uma área de ecótono Floresta-Cerrado (sazonalmente alagável) no Estado do Tocantins. Foram utilizadas medidas micrometeorológicas médias de $30 \mathrm{~min}$, do clima (temperatura e umidade do ar, precipitação, velocidade do vento), dos fluxos de radiação (solar, PAR, saldo de radiação) e fluxos turbulentos de calor sensível, latente e $\mathrm{CO}_{2}$, coletadas no Cerrado durante o período de 2001 a 2003, e no ecótono durante Outubro de 2003 a Setembro de 2004. O ecótono e o Cerrado estão sob solos arenosos, homogêneos, com alta capacidade de infiltração e baixa de armazenamento. O Cerrado s.s. mostrou-se um ecossistema com forte sazonalidade da capacidade fotossintética, do Albedo-PAR e dos fluxos atmosféricos de $\mathrm{CO}_{2}$. Há uma fase de sumidouro e outra de fonte de $\mathrm{CO}_{2}$, corroborando os dados da literatura. Na escala da variabilidade interanual, as variações dos estados funcionais do Cerrado, como sumidouro ou fonte de $\mathrm{CO}_{2}$, foram fortemente dependentes das variações da precipitação e da temperatura mínima. No ecótono Floresta-Cerrado, a fase de inundação induz à uma diminuição gradual da respiração do 
sistema e da produtividade primária. A diminuição na produtividade ocorre com um atraso de 45 dias, que poderia ser um tempo de assimilação e tolerância do sistema ao estresse induzido por anóxia. A redução da respiração do ecossistema ocorre ao passo que no regime alagado as perdas de $\mathrm{CO}_{2}$ ocorrem por evasão da superfície de água livre, um processo que aparentemente tem uma fonte de emissão menor que os processos de respiração do solo em condições secas. Durante a maior parte da inundação o ecótono continua a manter-se como um sumidouro de $\mathrm{CO}_{2}$ atmosférico durante, ao menos, 3 meses. O parâmetro RUE do ecótono foi cerca de 5 vezes maior do que o do Cerrado. A diferença de eficiência se deve possivelmente ao maior índice de área foliar das formações florestais da transição Floresta-Cerrado. A funcionalidade é controlada por fatores ambientais de maior escala que as locais. No caso do Cerrado s.s. há uma forte dependência do regime de chuvas e da temperatura mínima. No caso do ecótono Floresta-Cerrado, a suscetibilidade parece ser uma função do tempo de inundação. 


\title{
Functionality and seasonality on Cerrado and ecotone Forest-Cerrado: an inquiry with micrometeorological data of energy and $\mathrm{CO}_{2}$
}

\author{
Author: RAFAEL NORA TANNUS \\ Adviser: Prof. HUMBERTO RIBEIRO DA ROCHA
}

\section{SUMMARY}

This work discusses the energy and $\mathrm{CO}_{2}$ flux variability over a Cerrado Sensu stricto, in São Paulo state, Brazil, and over a seasonally inundated Forest-Cerrado ecotone in Tocantins state, Brazil. Micrometeorological measurements (30 minute average) of weather (temperature, relative humidity, precipitation and wind speed), radiation fluxes (solar radiation, PAR and net radiation), and $\mathrm{CO}_{2}$, latent and sensible heat turbulent fluxes were made for the Cerrado from 2001 to 2003. Measurements for the ecotone were made from October 2003 to September 2004. Both environments have sandy, homogeneous soils, with high infiltration capacity and low water storage. Cerrado s.s. showed strong seasonality for photosynthetic capacity, Albedo-PAR and $\mathrm{CO}_{2}$ atmospheric fluxes. As seen in other works, the Cerrado has both a $\mathrm{CO}_{2}$ sink and a $\mathrm{CO}_{2}$ source phase. These are strongly dependent on the precipitation and minimal temperature. Inundation of the Forest-Cerrado ecotone results in a gradual decrease in the system's respiration and primary productivity. A lag of approximately 45 days is seen in the primary productivity reduction. This could represent the system's resistance and tolerance due to anoxia stress. Ecosystem respiration in the inundated period is 
lower than in the dry period, apparently due to the lower $\mathrm{CO}_{2}$ outflux from the free water surface, in comparison with the $\mathrm{CO}_{2}$ flux from the soil. During most of the inundation period, the ecotone acts as a sink for $\mathrm{CO}_{2}$, for at least 3 months. The RUE for the ecotone was proximately 5 times higher than the Cerrado. This is probably due to the higher leaf area index of the forest area in the ecotone. The functionality of both biomes is controlled by larger scale environmental factors, as opposed to local factors. The Cerrado s.s. has a strong dependence precipitation and minimal temperature. The ForestCerrado ecotone shows a high dependence on the length of the inundated period. 


\section{INTRODUÇÃO}

A ecologia é o ramo da ciência que se propõe a estudar as interações entre os organismos. Pode ser dividida em sine-ecologia, demeo-ecologia, auto-ecologica e ecologia de ecossistemas. A sine-ecologia foca no estudo das comunidades, a demeoecologia no estudo das populações e a auto-ecologia no estudo dos indivíduos e das espécies.

O estudo dos ecossistemas pode ser realizado sob diferentes abordagens e pontos de vista, dentre elas ecologia de ecossistemas, análise de ecossistemas, pesquisa de ecossistemas, ecologia complexa, ecologia sistêmica são alguns dos nomes das abordagens mais comuns dentro da literatura (Muller, 1997).

Uma vez que "um sistema é mais do que a soma das partes" (Von Bertannfly, 1968), um ecossistema pode ser definido como sendo a unidade básica de interação entre componentes bióticos e abióticos em uma dada unidade espacial em um dado tempo (Muller, 1997). O estudo do ecossistema é, portanto, o estudo do todo ecológico de um determinado espaço e busca a compreensão do resultado final da interação de todas as partes.

"A vegetação é o reflexo do ambiente", frase de Alexander Von Humboldt, indica os primeiros elementos a serem considerados para o entendimento do ecossistema. O conjunto de elementos físicos, o histórico do local e a interferência biótica das proximidades determinam o estado do ecossistema. Os elementos bióticos serão selecionados pelo ambiente e irão, isoladamente e em conjunto, alterar as propriedades físicas do meio em que se encontram. Isto define o processo de retroalimentação entre a biota e o ambiente. O solo, o estado da atmosfera, a radiação solar e os ciclos geoquímicos são os principais parâmetros físicos no estudo da vegetação. 
Existe uma grande diferença na velocidade da alteração destes parâmetros. A atmosfera altera o seu estado no decorrer de um dia enquanto que o solo leva muitos anos para alterar o seu estado, quer seja químico ou mecânico. Portanto, dependendo da abordagem e das análises do estudo, os parâmetros são considerados dinâmicos ou estáticos.

$\mathrm{Na}$ análise do elemento biótico do sistema é fundamental contabilizar dois aspectos. O primeiro, a caracterização da estrutura física da vegetação, como a altura, a profundidade das raízes, a proporção entre os componentes lenhosos e herbáceos, ou de forma sintética uma descrição física da paisagem. O outro seria o funcionamento fisiológico da vegetação, ou seja, o tipo fisiológico, sua faixa de funcionamento ecológico, ou sinteticamente, o seu modo de interação com as forçantes ambientais.

Existem sistemas que apresentam elevada sazonalidade de funcionamento e outros que apresentam padrões mais estáveis. Isto se deve tanto ao tipo de vegetação do ecossistema, quanto ás forçantes ambientais. No Brasil, como exemplos de alta sazonalidade temos, um campo de estrato herbáceo de ciclo anual (campo limpo) e o Cerrado, com o seu componente arbóreo-arbustivo semidecidual. Como exemplos de baixa sazonalidade podemos mencionar a floresta tropical Amazônica nas proximidades de rio Tapajós, que apresenta uma menor variação em termos de funcionamento (Goulden et al., 2004). A sazonalidade é primeira descrição do comportamento do sistema no tempo.

Medições e experimentos são feitos complementar ou independentemente em ambos os componentes do sistema, biótico e abiótico, no maior numero possível de aspectos, com o intuito de compreender e a caracterizar o funcionamento do ecossistema.

Todo o componente biótico do sistema está submetido ao processo evolutivo. Este pode ser resumido como a soma entre as pressões internas do componente biótico (como competição e predação) e a pressão exercida pelo ambiente. Portanto, o processo histórico das alterações ambientais é concorrente com o processo histórico das alterações do componente biótico. A caracterização dos componentes biótico e abiótico do sistema, e a sua parametrização em elementos estáticos e dinâmicos, descrevem a relação entre 
biótico e abiótico no tempo, que é, portanto, o resultado da seqüência histórica-evolutiva de um determinado ecossistema.

Tanto a alteração do componente biótico, por exemplo pela introdução de espécies, quanto a alteração de um dos componentes físicos, como por exemplo a alteração de temperatura, levam a uma perturbação da relação biótico-abiótico. Sendo que esta pode estar acima da capacidade de recuperação do ecossistema, ou da capacidade de resiliência do sistema (na definição ecológica do termo) (Gunderson et al., 2002).

Segundo a hipótese vigente, a atmosfera está em processo de aquecimento, devido ao aumento na concentração de gases de efeito estufa. As previsões apontam para um aumento entre 1 a $6{ }^{\circ} \mathrm{C}$ na temperatura média nos próximos 100 anos, sendo que este aumento poderá ocorrer tanto na temperatura média como na redução da amplitude da temperatura máxima e mínima, ou em ambas (IPCC, 2001). Algumas previsões apontam para um aumento da intensidade de tempestades, da severidade de secas e mudanças na circulação das correntes oceânicas, levando à aceleração do ciclo hidrológico, culminando em cenários catastróficos (Schwartz \& Randall, 2003).

As conseqüências do aquecimento são inúmeras e incertas para a integridade dos ecossistemas terrestres, devido ao pouco conhecimento da dinâmica dos ecossistemas e da alteração natural da paisagem. Uma vez que não há perspectiva da desaceleração do efeito estufa a curto prazo, o estudo da susceptibilidade dos ecossistemas ás mudanças ambientais torna-se ainda mais importante para subsidiar políticas ambientais de conservação e sustentabilidade.

Um estudo de susceptibilidade se beneficia do monitoramento de um ecossistema e da caracterização de seu funcionamento no estado atual. O período de maior susceptibilidade dos ecossistemas é quando a vegetação está sob qualquer forma de estresse. Sendo estresse definido como o momento quando uma alteração das condições ideais de vida de uma espécie ou de um grupo de espécies provoca alterações em diversos, ou todos, os níveis funcionais do organismo, de forma reversível ou não (Larcher, 2000). Assim, juntamente com as previsões de aumento de temperatura 
mínima, que comumente são os períodos de maior estresse da vegetação, conclui-se que a principal fase do monitoramento de um sistema é o período de maior estresse.

Esta definição traz duas importantes conclusões: no caso de existência de grupos concorrentes, formados por espécies, ou por grupos de indivíduos distintos, que estejam sobre o mesmo regime de estresse, um grupo pode ser mais favorecido que o outro. $\mathrm{O}$ estresse é um dos principais mecanismo na seleção natural. Portanto, o estresse age em duas escalas, na das populações, selecionando os indivíduos mais adaptados, e na da comunidade, selecionando os componentes estruturais que se melhor se ajustam à nova condição.

O monitoramento da interação entre biótico-abiótico de um mesmo ecossistema em vários estados auxilia a caracterizar o seu funcionamento e o seu padrão de variação perante um determinado conjunto de forçantes e estresses. Com isto se torna possível conhecer a sazonallidade da relação biótico-abiótico, determinar as principais fontes de estresse e estimar a capacidade de resiliencia do sistema às perturbações.

O Brasil possui um grande número de biomas (Figura 1). Em extensão, o maior é a Floresta Tropical, seguido pelo Cerrado, considerado uma área de grande importância ecológica, tanto pela sua diversidade de fisionomias e de espécies, quanto pela alta taxa de desmatamento nos últimos anos (Myers et al., 2000). 


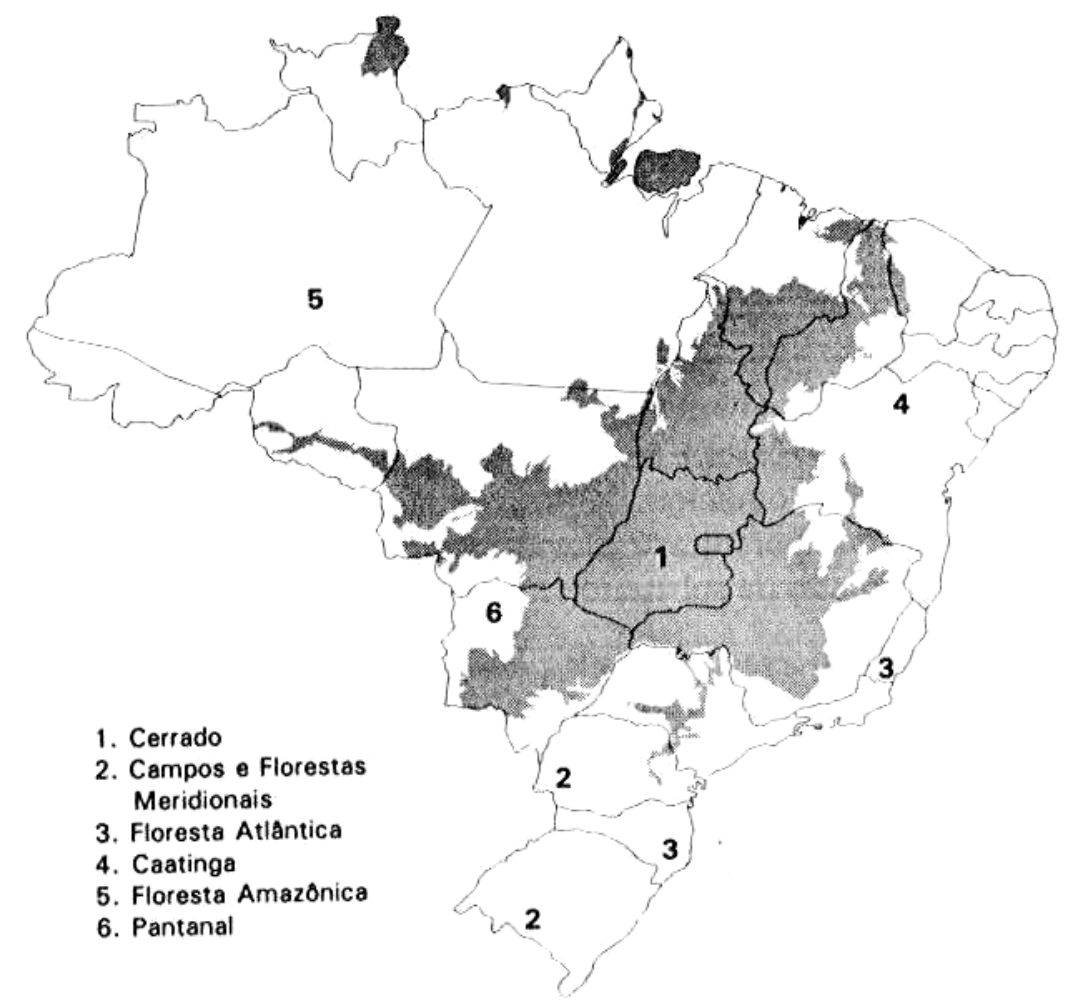

Figura 1 - Distribuição dos Biomas no Brasil. (Ribeiro \& Walter 1998)

O Cerrado é uma formação vegetal que apresenta diversas classificações e nomenclaturas. No presente trabalho adota-se a classificação clássica de Coutinho (1978) que o classifica como uma zona de ecótono entre um campo limpo e um cerradão, contendo neste intervalo as fisionomias de campo sujo, campo cerrado e Cerrado Stricto Sensu. A priori, a definição de Cerrado é fisionômica, ou seja, não é feita com base de espécies chaves ou comportamentos do ecossistema perante as forçantes ambientais. Apresenta problemas para uma classificação florística, uma vez que apresenta duas floras distintas, a herbácea e a arbóreo-arbustiva, e isto dificulta o estabelecimento de espécies chave para a sua classificação (possível apenas dentro de suas fisionomias e floras) (Coutinho 1978).

O Cerrado é classificado de acordo com a sua fisionomia vegetal. O estado fisionômico reflete o resultado do funcionamento e equilíbrio ecológico de longo prazo. 
De acordo com a literatura recente existem quatro grandes abordagens em relação aos mecanismos que determinam a fisionomia do Cerrado.

A primeira abordagem credita ao fogo o papel regulador das fisionomias e consequentemente da origem do bioma (Coutinho 1990, Miranda et al., 2002). Especulações sobre a origem do fogo, se natural ou antropogênica (indígena) também foram levantadas (Rawitcher, 1948). Porém, incêndios na região do Cerrado, datados através de amostras de carvão polén, ocorreram até 32.000 anos atrás (Ledru, 2002; Coutinho, 1990), o que seria consideravelmente antes da chegada do homem na América, que ocorreu por volta de 9500 anos atrás, Neves et al., 2003. O efeito do fogo é diferencial em cada estrato da vegetação, sendo o componente herbáceo favorecido em detrimento do árbóreo. Logo após a passagem do fogo ocorre uma rápida disponibilização de nutrientes na camada superficial do solo e estes seriam absorvidos preferencialmente pelo estrato herbáceo, devido ao sistema radicular mais superficial. Está abordagem também se baseia no fato de muitas espécies do Cerrado serem adaptadas ao fogo e outras serem dependentes do fogo para a sua reprodução e dispersão (Coutinho, 1990; Miranda et al., 2002).

A segunda abordagem considera o solo o mecanismo regulador de controle das fisionomias do bioma. Os solos sob o Cerrado são tipicamente profundos, bem drenados, ácidos e distróficos (Mota et al., 2002; Haridasan 2000). Áreas com os solos mais ricos suportariam as fisionomias de maior biomassa ( por exemplo o Cerradão), enquanto que as áreas com os solos mais pobres suportariam as fisionomias de menor biomassa (por exemplo Campo Limpo) (Goodland \& Pollard 1973). A diferença entre os solos sob cada fisionomia não se limita apenas à quantidade de nutrientes, já que a quantidade de argila, e consequentemente a capacacidade de retenção de água do solo, é um fator igualmente importante. (Ruggiero et al., 2002)

A terceira abordagem é uma variante da abordagem anterior. Os solos sob Cerrado, além de distróficos, apresentam também altas concentrações de aluminio (Al). Em solos ácidos, ocorre uma maior solubilização do aluminio $\left(\mathrm{Al}^{3+}\right)$, aumentando a sua capacidade de circulação no ambiente. Uma vez solubilizado no solo, pode ser absorvido pelas raízes, sendo extremamente tóxico para as plantas. Dentro das plantas, o $\mathrm{Al}^{3+}$ irá 
ocupar os canais de cálcio das células vegetais, impedindo o funcionamento do complexo cálcio-calmodulina, o que dentre outras coisas, impediria a mitose (Larcher, 2000). Portanto, para esta abordagem, a toxidez do solo, juntamente com a baixa disponibilidade de nutrientes, seria o mecanismo regulador das fisionomias (Goodland \& Pollard, 1973).

A quarta abordagem aponta para um controle climático das fisionomias, sendo estabelecido um gradiente crescente de precipitação do Campo para o Cerradão (ver as referencias citadas por Rawitcher, 1948).

Uma análise crítica das quatro abordagens nos permite concluir que todas estão em algum ponto certas e em outros erradas.

O bioma Cerrado se distribui ao longo de mais de $15^{\circ}$ de latitude. Assim, apresenta as suas diferentes fisionomias em diversas condições ambientais. A variação da temperatura média anual varia entre 18 e $28{ }^{\circ} \mathrm{C}$, enquanto que a precipitação varia de 750 a 2000 mm por ano, sempre com uma estação seca bem definida (Oliveira-Filho \& Ratter, 2002; Ribeiro \&Walter, 1998). Potencialmente, o "climax-climático" da região do Cerrado seria de uma floresta tropical decidual (Walter, 1970; Coutinho, 1990). A análise de amostras de solo em diferentes locais tem demonstrado que não apenas o teor de Al entre o Cerrado S.S. e o Cerradão são similares (Haridasan, 1992), como a quantidade de nutrientes no solo sob diferentes fisionomias não é significantemente diferente (Ruggiero et al., 2002). Apesar de algumas áreas no Estados de São Paulo, Minas Gerais e em Brasília (DF) alterarem a sua fisionomia para fisionomias mais densas ao serem protegidas do fogo, isto não pode ser extrapolado para outras áreas, uma vez que a qualidade e a profundidade do solo, bem como a altura da placa laterítica podem alterar consideravelmente esta dinâmica. (Coutinho, 1990). Assim, fica claro que não existe um único mecanismo controlador das fisionomias e consequentemente não existe um único mecanismo controlador da distribuição do bioma Cerrado.

Os biomas terrestres não apresentam uma separação nítida entre si. Apresentam em sua interface uma zona transicional denominada ecótono. Nesta zona de transição, as duas vegetações coexistem, sobre as mesmas condições climáticas, dentro de um intenso regime de competição, formando um gradiente entre os biomas. O sucesso de um bioma 
em detrimento do outro será determinado por condições microclimáticas, pela variação do relevo e pelas propriedas do solo (Walter, 1970).

A zona de transição entre o Bioma Amazônico e o Bioma Cerrado ocorre ao longo de toda a interface na distribuição entre estes dois biomas (Figura 01). Esta zona de transição se moveu ao longo do tempo, tendo tanto a Floresta quanto o Cerrado expandido e contraído os seus domínios em função das condições ambientais, ou ainda "Tudo indica que os "estoques" das vegetações do Brasil, flutuaram em espaço a mercê da flutuação paleoclimática" ( Ab'Saber, 1982).

Após o final da ultima glaciação (Würn-Wisconsin) o clima está mais favorável para a expansão da Floresta (Prance, 1982). Esta afirmação é corroborada por observações de remanecentes gigantes de espécies de Cerrado na área de Floresta no MT, que apontam para o deslocamento da fronteira Floresta-Cerrado, aumentando a área de Floresta (Ratter, 1992). O mesmo foi observado na Ilha de Maracá, Acre, devido a uma aparente diminuição das queimadas naturais (Eden \& McGregor, 1992).

Resultados de modelagem atmosférica associados com um modelo SVATS (Soil Vegetation Atmosphere Transfer Scheme) indicam que, se mantidas as elevadas taxas de desmatamento, as alterações climáticas decorrentes podem levar a um processo de "savanização" da Amazônia (Nobre et al., 1991), ou seja, um deslocamento da fronteira Floresta-Cerrado para o interior da Floresta. Resultados de modelagem de superfíce baseados nas taxas de evapotranspiração dos dois biomas também apontaram para um deslocamento da área de Cerrado em direção à Floresta (Sterberg et al., 2001).

A compreensão do funcionamento das áreas de ecótono entre Floresta-Cerrado, bem como o monitoramento da Floresta e do Cerrado, são fundamentais para compreender o mecanismo de deslocamento dos biomas e o destino destes perante as mudanças ambientais.

No presente momento, a Floresta Amazônica está sendo monitorada em diversos pontos por estações micrometeorológicas automáticas associadas a sistemas de monitoramento de fluxos de água e $\mathrm{CO}_{2}$ (Rocha et al., 2004; Saleska et al., 2003).

O presente trabalho descreve os funcionamentos e as sazonalidades de duas diferentes áreas através de estações micrometeorológicas automáticas associadas a 
sistemas de medições de fluxo de $\mathrm{CO}_{2}$ e água. A primeira área se localiza no Estado de São Paulo, sendo uma área de Cerrado s.s., sem queima, onde foi possível realizar uma analise da variabilidade interanual e iniciar a discussão sobre o funcionamento hídrico do Cerrado. A segunda, uma área alagável de ecótono Floresta-Cerrado, no Estado do Tocantins, iniciando uma discussão sobre o funcionamento do ecótono Floresta-Cerrado. O trabalho buscou caracterizar, analisar e comparar os períodos de maior estresse e maior produtividade para as duas áreas. Além, da aplicação e do desenvolvimento de indíces descritivos do funcionamento dos ecossistemas. 


\section{MATERIAL E MÉTODOS}

\subsection{Cálculo de Umidade Volumétrica}

Para o Cerrado s.s foram utilizadas constantes de calibração obtidas em laboratório (Bruno, 2004). A calibração dos sensores na área de ecótono FlorestaCerrado foi realizada utilizando as constantes de calibração do manual (Campbell Scientific, 1996) do equipamento para solos arenosos.

\subsection{Técnica da Correlação dos vórtices turbulentos}

A técnica de correlação dos vórtices turbulentos (eddy-correlation) é um método de medição dos fluxos de massa e energia da superfície (Moncrieff et al., 1997 a). Tem como objetivo principal estimar o transporte turbulento entre a superfície e a atmosfera. O monitoramento da turbulência através de um único ponto de observação baseia-se na

hipótese de "congelamento" da turbulência, conhecida como hipótese de Taylor. Isto implica que os vórtices não sofrerão mudanças enquanto estiverem sendo medidos, uma simplificação feita quando o tempo de medida é maior que o tempo necessário para o vórtice ser analisado pelo sensor (Stull, 1988) Descrevendo matematicamente a técnica, consideremos que os valores de uma variável x varie com o tempo. Dado um certo intervalo de tempo, podemos definir o valor de x em um dado instante t, como :

$$
\mathrm{x}=\overline{\mathrm{x}}+\mathrm{x}^{\prime}
$$


onde:

$\overline{\mathrm{x}}$ é o valor médio de $\mathrm{x}$ no intervalo de tempo

$\mathrm{x}^{\prime}$ é o valor do desvio em relação à média um dado instante $\mathrm{t}$.

Podemos considerar então o valor de x', como a flutuação neste dado instante t, uma vez que :

$$
x^{\prime}=x-\bar{x}
$$

Suponhamos a necessidade de se calcular o fluxo medido no intervalo de tempo, Fc, de um dado escalar "c". Este pode ser definido como sendo $\boldsymbol{W C}$, onde "c" é valor da concentração do escalar e "w" o vento médio vertical.

Reescrevendo Fc temos :

$$
\begin{aligned}
& \overline{w C}=\overline{\left(\bar{w}+w^{\prime}\right)\left(\bar{c}+c^{\prime}\right)} \\
& \overline{w C}=\overline{\left(\overline{w c}+\bar{w} c^{\prime}+w^{\prime} \bar{c}+{ }^{\prime} w^{\prime} c^{\prime}\right)}
\end{aligned}
$$

Como a média de um desvio é sempre zero, resulta :

$$
\overline{w C}=(\overline{w C})+\left({ }^{\prime} w^{\prime} c^{\prime}\right)
$$

Supondo que $\overline{\mathrm{w}}$ é zero (o que pode ser aproximado por uma técnica de rotação dos eixos), temos que :

$$
\overline{W C}=\overline{\left(W^{\prime} C^{\prime}\right)}
$$


Para obtermos os valores de fluxo em unidade de massa, multiplicamos o fluxo pela densidade do ar ( $\rho$ ). Enfim, temos, para medidas discretas :

$$
\mathrm{Fc}=\frac{1}{T} \rho \sum(\mathrm{w}-\overline{\mathrm{w}})(\mathrm{c}-\overline{\mathrm{c}})
$$

Esta somatória ocorre dentro de um intervalo de tempo estabelecido, o mesmo dos valores médios, chamada de covariância entre a concentração do escalar c e a velocidade vertical do vento.

A escala característica de tempo turbulento na camada de mistura planetária é de 15 a 30 minutos. Este tempo determina o tempo de integração para que a covariância possa medir tanto os efeitos dos turbilhões menores, quanto dos maiores. Isto significa medir tanto a velocidade vertical do vento, quanto à concentração do escalar c, em alta freqüência. Para tal utiliza-se um anemômetro sônico, que realiza medidas de $10 \mathrm{~Hz}$, e um sensor de análise de gases por infravermelho. Convenciona-se o sinal dos fluxos de superfície como sendo positivo quanto da superfície para a atmosfera , e negativo quanto da atmosfera para a superfície.

Como toda a técnica, esta possui limitações. Como se baseia em turbulência (atmosfera misturada) para estimar os fluxos, no caso de estabilidade atmosférica as estimativas podem ser questionáveis. Quando há uma forte estabilidade noturna dentro e acima do dossel, ocorre um acumulo do ar dentro do dossel, ou seja, não há transporte vertical e conseqüentemente o fluxo de $\mathrm{CO}_{2}$ da vegeção para a atmosfera não é corretamente medido. Desta forma, ocorre uma subestimativa dos fluxos noturnos de $\mathrm{CO}_{2}$, o que acarretaria uma subestimativa dos fluxos noturnos.

Uma correção para se avaliar a soma anual foi proposta, utilizando um limiar de u* para sinalizar se em um dado horário noturno houve suficiente mistura ou não (Goulden et al., 1996).

Assim, os fluxos noturnos com pouca turbulência seriam substituídos por outros valores para o fim de se calcular a soma anual. Isto pode ser obtido de várias formas : 
modelagem numérica da respiração da biota (Rocha et al., 2002) ; com valores obtidos em noites com mistura adequada próxima ao evento (Saleska et al., 2003)

\subsubsection{Correção de Riehl}

A correção de Riehl (Riehl, 1979) é aplicada ao fluxo de calor sensível (Hs), especialmente para altas condições de umidade do ar. O método de cálculo do fluxo de calor sensível leva em conta apenas o calor específico do ar (cp) , ou seja

$$
\text { Hs }=\bar{\rho} \text { ср } \overline{\boldsymbol{w}^{\prime} \boldsymbol{T}^{\prime}}
$$

onde

$\bar{\rho}$ é a densidade do ar

$\boldsymbol{W}^{\prime} \boldsymbol{T}^{\prime}$ é a covariância entre o vento vertical (w) e a temperatura(T).

Porém,

$$
\frac{\mathrm{cV}}{\mathrm{cpd}}=1,83
$$

onde cv é a capacidade térmica do vapor de água e cpd é a capacidade térmica do ar seco. Com isto, "a quantidade de calor necessária para aquecer em $1{ }^{\circ} \mathrm{C}$ uma grama de água é quase o dobro da necessária para aquecer uma grama de ar seco".( Riehl, 1979). Logo

$$
\mathrm{cpT}=\operatorname{cpd}(1+0,83 q)
$$

E sendo assim, o fluxo de calor sensível passa a ser : 


$$
\text { Hs }=\bar{\rho} \operatorname{cpd}\left(\overline{\boldsymbol{w}^{\prime} \boldsymbol{T}^{\prime}}+0.83 \overline{\mathrm{w}^{\prime} \mathrm{q}^{\prime}} \overline{\mathrm{T}}\right)
$$

onde q é a umidade específica

\subsubsection{Correção de Webb}

A correção de Webb (Webb et al., 1980), aplicada aos valores de fluxo de $\mathrm{H}_{2} \mathrm{O}$ e $\mathrm{CO}_{2}$ medidos por analisadores de gás por infravermelho (IRGA) de caminho aberto, parte do princípio que devido à diferença de temperatura do ar ocorrerá modifica as densidades das massas de ar, ascendentes e descendentes. Para que a continuidade de massa seja garantida, a velocidade das parcelas ascendentes deve ser maior que a das parcelas descendentes (Liebethal \& Foken, 2003). A correção não se aplica aos IRGAs de caminho fechado pois o gás é analisado pelo instrumento sempre à mesma temperatura e pressão, inalterando assim a densidade da parcela de ar medida.

É esperado que uma variação de 2 a 3 \% no valor do calor sensível calculado , promova até $20 \%$ no do fluxo do calor latente e $\mathrm{CO}_{2}$ (Liebethal \& Foken, 2003).

Uma formulação possível para a correção dos fluxos :

$$
\text { Le }=(1+\mu \sigma)\left[\overline{\mathrm{W}^{\prime} \rho_{\mathrm{v}}}+\left(\rho_{\mathrm{v}} / \overline{\mathrm{T}}\right) \overline{\mathrm{W}^{\prime} \mathrm{T}^{\prime}}\right)
$$

(Leuning \& Moncrieff 1990)

E para o fluxo de $\mathrm{CO}_{2}$ :

$$
\mathrm{FC}=\overline{\mathrm{W}^{\prime} \rho_{\mathrm{c}}}+\rho_{\mathrm{c}}\left[\left(\mu \mathrm{w}^{\prime} \rho_{\mathrm{c}}^{\prime} / \bar{\rho}_{\mathrm{a}}\right)+(1+\mu \sigma)\left(\overline{\mathrm{W}^{\prime} \mathrm{T}^{\prime}} / \overline{\mathrm{T}}\right)\right]
$$

(Leuning \& Moncrieff 1990) 
onde " $\mu$ " é razão entre a massa molecular do ar seco e do vapor d'água, " $\sigma$ " razão entre a densidade do ar seco e do do vapor d'água, $\bar{\rho}_{\mathrm{c}}$ é a densidade média do escalar "c" e $\rho_{\mathrm{v}}$ a densidade do vapor d'água.

\subsubsection{Armazenamento, Inundação e NEE}

Como já descrito, a ausência de turbulencia leva a um acumulo de $\mathrm{CO}_{2}$ na atmosfera dentro do dossel. Além da correção utilizando a velocidade de arrasto é possível não subestimar os fluxos noturnos calculando o $\mathrm{CO}_{2}$ armazenado na coluna. A concentração de $\mathrm{CO}_{2}$ foi medida na coluna através de um perfil de monitoramento de 7 níveis. A união do ponto médio entre os nívies do perfil com outro ponto médio forma uma camada. A forma de cálculo (Von Randow et al., 2004) de armazenamento utilizada foi :

$$
\operatorname{Arm}=\int M c \frac{d C}{d t} d z
$$

onde

Arm é o armazenamento na coluna.

Mc é o peso molar do carbono

dz é a variação de altura

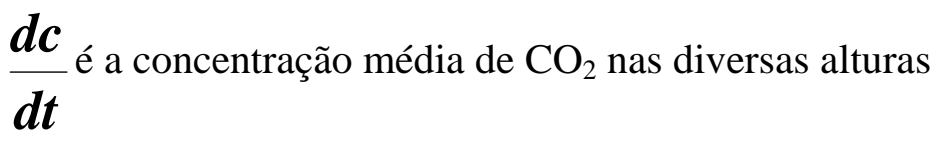

Ao total foram instalados 7 níveis de perfil conectados a um IRGA localizado na base da torre. O oitavo perfil considerado é o IRGA de caminho aberto do sistema de mediçào de fluxos. Inicialmente foram instalados 3 níveis em uma boia (Figuras 6 e 7). Com o advento da inundação a espessuras das camadas foram se alterando. As espessuras das camadas foram então recalculadas para cada altura de inundação. A altura 
da inundação foi estimada usando uma régua de termopares instaladas na torre e na bóia de monitoramento.

Os dados do início da inundação foram perdidos devido a um problema no sistema de aquisição de dados. Após alguns meses de monitoramento a bóia de monitoramento sofreu avarias, gerando uma segunda lacuna nos dados. Uma vez inutilizada a bóia os níveis foram fixados na torre experimental .

A troca líquida do Ecossistema (NEE) foi calculado como sendo a soma dos fluxos turbulentos e o Armazenamento na coluna.

\section{NEE $=$ Fc + Armazenamento}

\subsection{Sítios Experimentais}

De forma resumida, para se monitorar os fluxos de $\mathrm{CO}_{2}$ e água, utilizando o método da correlação dos vórtices turbulentos, sobre uma dada área são necessários alguns requisitos.

A área que contém o objeto de estudo deve ser suficientemente plana; distante de acidentes geográficos como montanhas ou morros; ter os seus entornos livre de possíveis fontes de contaminação (com atenção especial na direção do vento predominante) e uma torre significativamente alta (acima do dossel) para a realização das medidas. As duas áreas estudadas seguem estas diretrizes. 


\subsubsection{Sítio Experimental ecótono Floresta-Cerrado.}

O sítio experimental do ecótono Floresta-Cerrado, doravante BAN, está sobre uma área no Parque Estadual do Cantão, no estado do Tocantins, localizado a $9^{\circ}$ 49'16.1“ S 50 08'55.3“ W, com altitude aproximada de 120 metros (Figuras 02, 03 e 04).

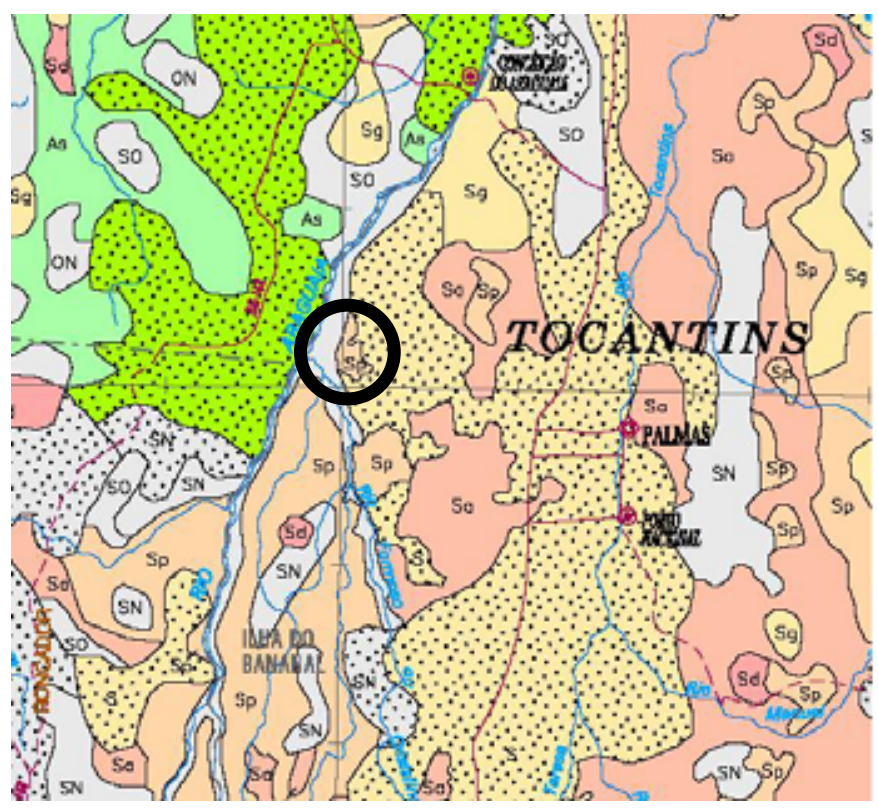

Figura 2 - Recorte do mapa da vegetação do Brasil (IBGE 2004). As cores verdes e esverdeadas indicam locais com floresta ombrófila densa. As cores amarelo e amareladas indicam áreas de Cerrado. As cores cinzas indicam áreas de tensão ecológica. O círculo preto indica a localização aproximada do sítio experimental

O sítio experimental encontra-se em uma área de tensão ecológica entre Floresta e Cerrado (classificação SO - IBGE 2004). 


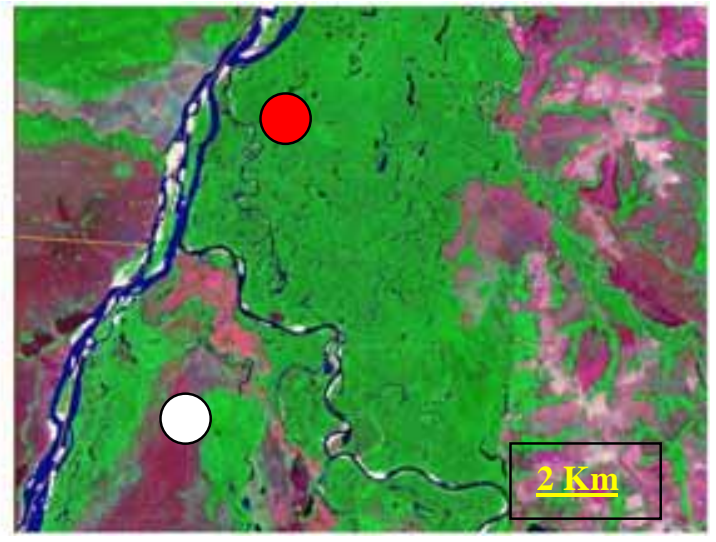

Figura 3 - Imagem de satélite mostrando a área. O ponto colorido indica a posição da torre. O ponto branco a Ilha do Bananal

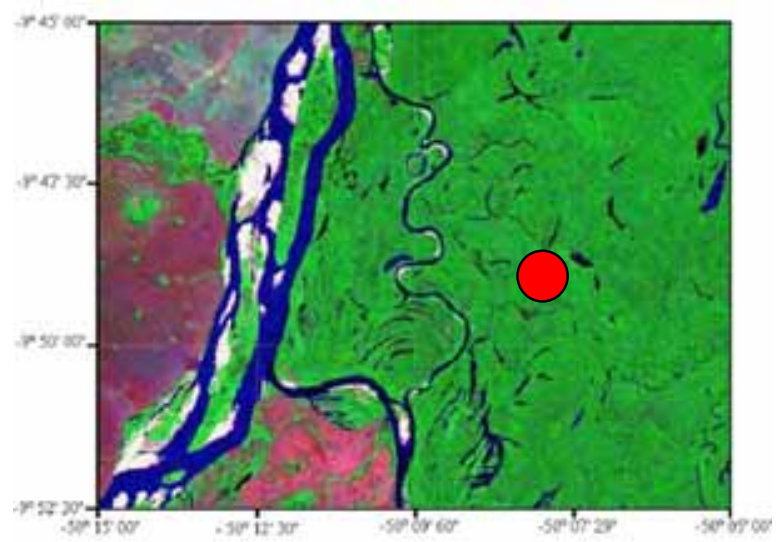

Figura 4 - Imagem em detalhe. O rio de maior porte na Figura é o Rio Araguaia. $\mathrm{O}$ ponto colorido indica a posição da torre

A área de ecótono Floresta-Cerrado contém uma extensa formação florestal alagável, uma fisionomia de Cerrrado s.s. e um campo. Formações savânicas, como o Cerrado, que são submetidas a inundações sazonais e a um período de seca também podem ser definidas como savanas hipersazonais e são tipícas das áreas de contato entre Floresta-Savanna, ou no caso, Floresta-Cerrado (Sarmiento, 1984). O campo, que também pode ser incluido na definição de savanna hipersazonal, é provavelmente um campo úmido, submetido a um regime de inundação mais frequente.

Os dados apresentados e discutidos neste trabalho, para este sítio experimental, foram coletados entre outubro de 2003 e setembro de 2004. 


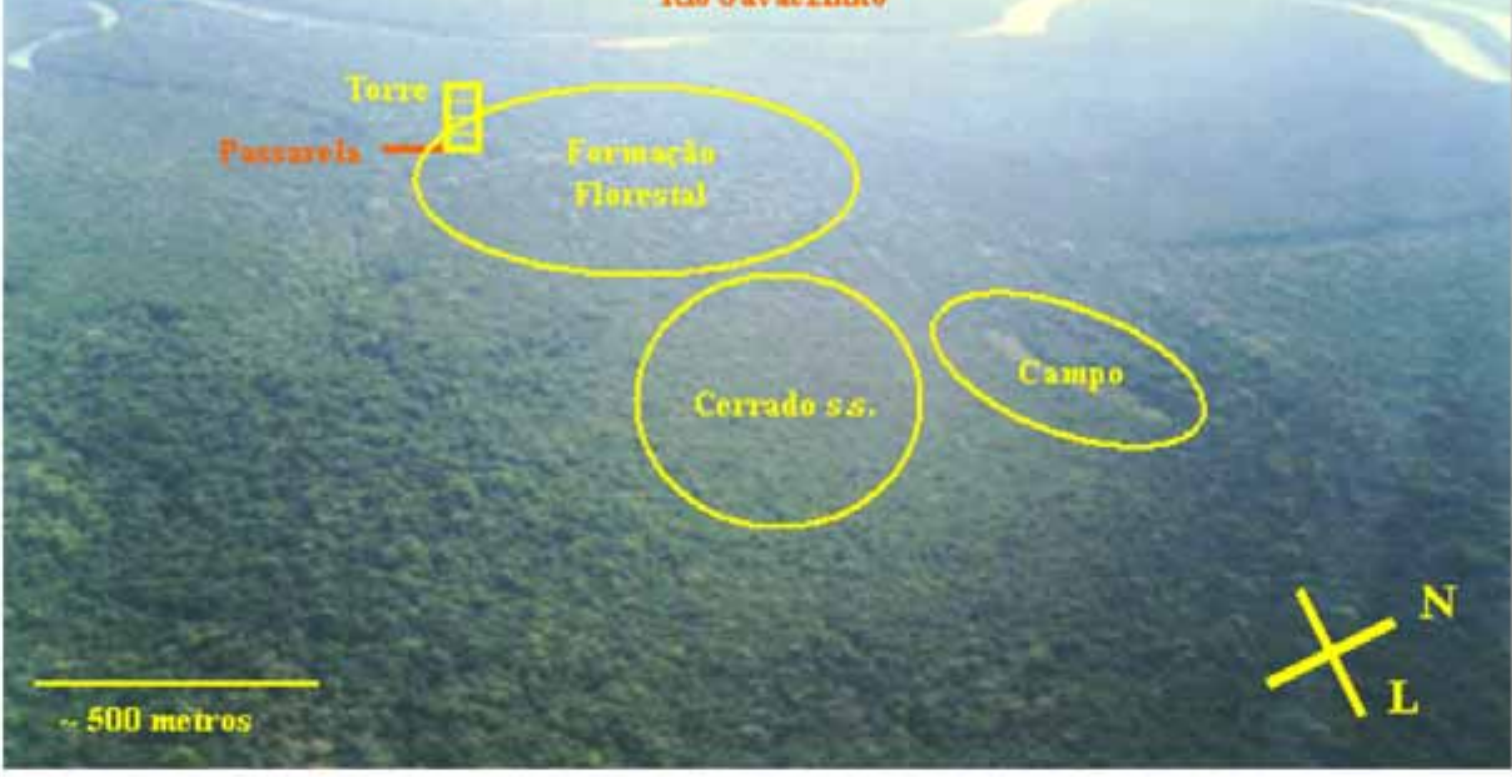

Figura 5 - Foto aérea do sítio experimental do ecótono Floresta-Cerrado com a delimitação aproximada dos biomas. Fotografia aérea : Humberto Ribeiro da Rocha

Os sensores estão sobre uma à torre, do tipo 'scaffolding' (escadas e plataformas) de ferro galvanizado, com seção horizontal 1x 2 m, 40 m de altura. (Figuras 04 e 05). Dois módulos de madeira a $12 \mathrm{~m}$ de altura servem como abrigo para baterias, quadros elétricos com datalogger e outros acessórios. A alimentação é 12 VDC, recarregada com dois conjuntos de painéis solares a aproximadamente $26 \mathrm{~m}$ de altura. Parte do instrumental foi desenhado para a inundação e para a seca. Durante a seca e a cheia o perfil de $\mathrm{CO}_{2}$ será monitorado através de um sistema flutuante. 


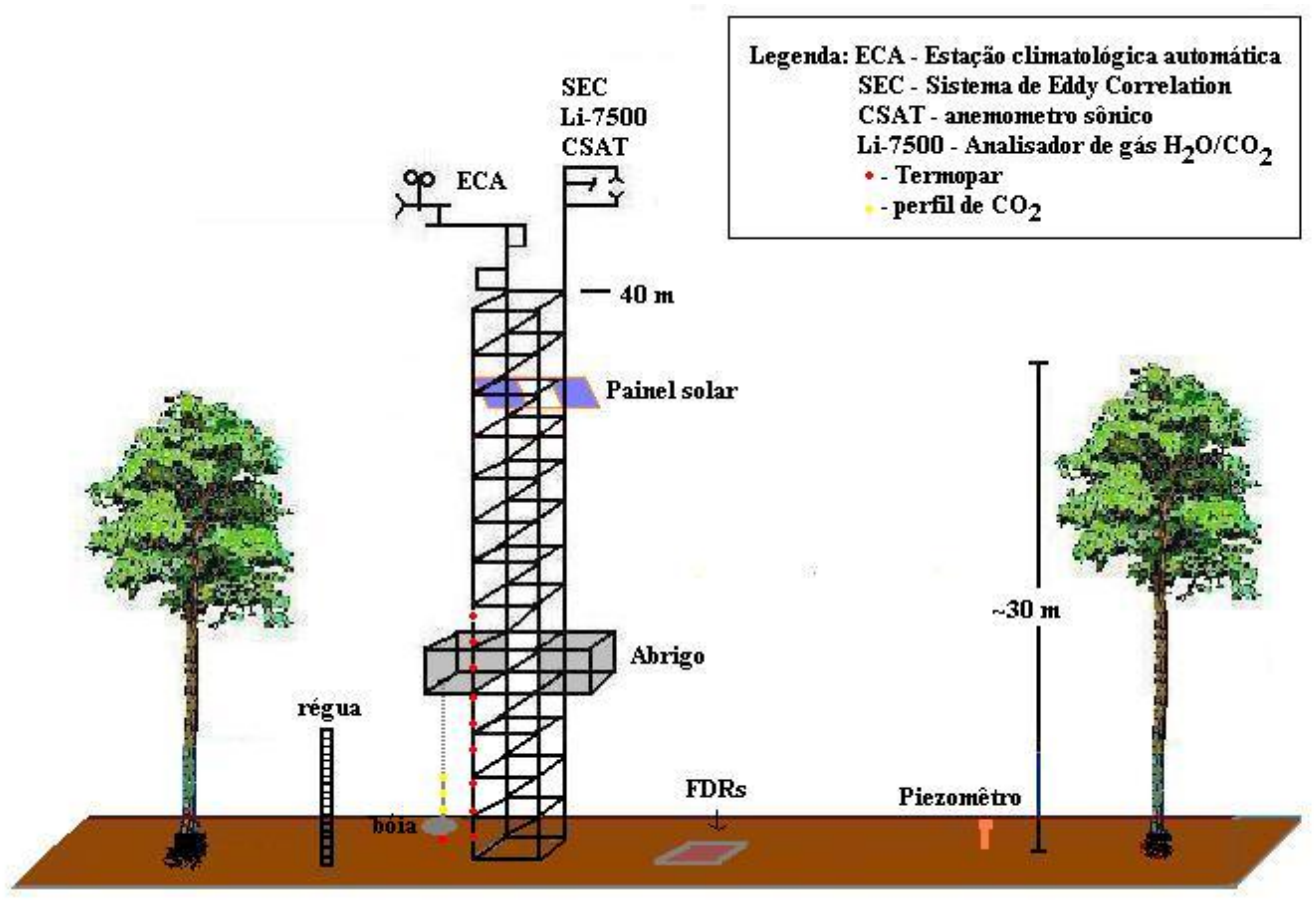

Figura 6 - Desenho esquemático da estação durante a fase seca. Desenho : Leuda Oliveira

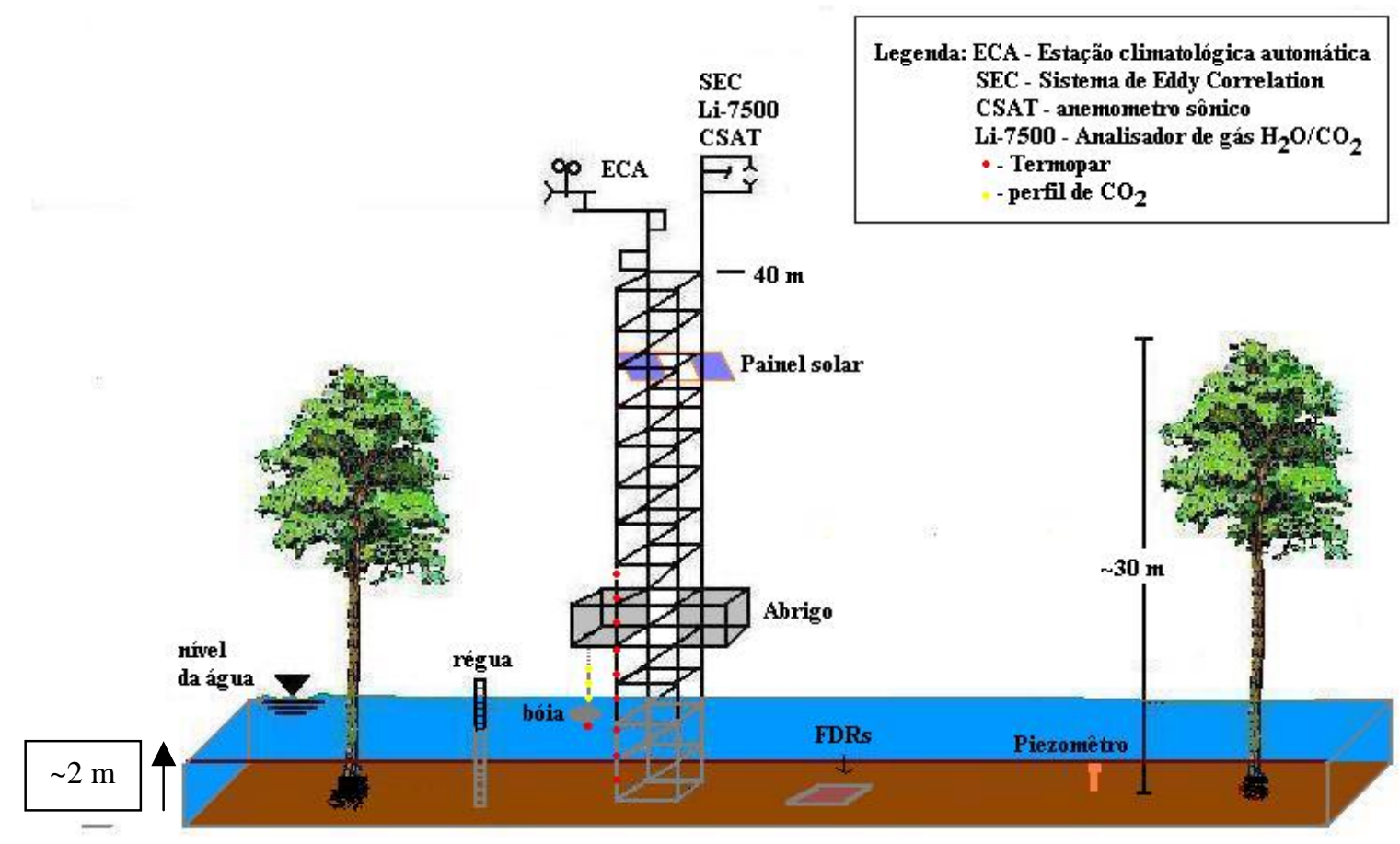

Figura 7 - Desenho esquemático da estação durante o período de inundação. Desenho: Leuda Oliveira 


\subsubsection{Sítio Experimental do Cerrado Sensu stricto (s.s.)}

A área de Relevante Interesse Ecológico (ARIE) da Gleba Pé de Gigante, administrada pelo Instituto Florestal tem 1060 ha no território do Parque Estadual da Vassununga em Santa Rita do Passa Quatro, SP, (Figura 08) com altitude variando entre 660 e $730 \mathrm{~m}$, situada entre $47^{\circ} 34^{\prime}$ a $47^{\circ} 41^{\prime}$ W e $21^{\circ} 36^{\prime}$ a $21^{\circ} 44^{\prime}$ 's. Na estação climatológica mais próxima do sítio experimental (DAEE-Santa Rita do Passa Quatro), a precipitação anual é de $1478 \mathrm{~mm}$ e a temperatura do ar de 22,8 ${ }^{\circ} \mathrm{C}$ (Rocha et al., 2004a). Segundo Batalha (1997) na área coexistem variações fisionômicas do Cerrado (Fig. 3.1.2): (i) Cerradão (11,1\% da área) com árvores predominantes de $10 \mathrm{~m}$ sem um dossel totalmente formado, com componente herbáceo predominante de plântulas, pouco desenvolvido, e com muita serrapilheira; (ii) Cerrado Restrito (79\% da área) com arbustos e arvoretas de $5 \mathrm{~m}$ de altura em média e grande adensamento, árvores emergentes de 7 a $10 \mathrm{~m}$ de altura, com extrato herbáceo-subarbustivo contínuo e mais desenvolvido que no Cerradão; (iii) Campo cerrado (7,9\% da área) com esparsos arbustos de até $2 \mathrm{~m}$ de altura e árvores de 7 a $10 \mathrm{~m}$ de altura, predominantemente ocupado pelo extrato herbáceo-subarbustivo onde pode-se locomover facilmente; (iv) Campo sujo (0,25\% da área) predominante nas encostas íngremes, com gramíneas de 50 cm de altura e manchas de solo exposto; (v) Campo úmido (0,55\% da área) nas áreas de drenagem do córrego Paulicéia, com gramíneas e ciperáceas de até $1 \mathrm{~m}$ de altura e manchas de espécies invasoras (vi) Floresta estacional semidecídua (1,2\% da área) com espessa e contínua camada de serrapilheira, árvores acima de $15 \mathrm{~m}$ formando um dossel e árvores emergentes com cerca de 20 de altura. 


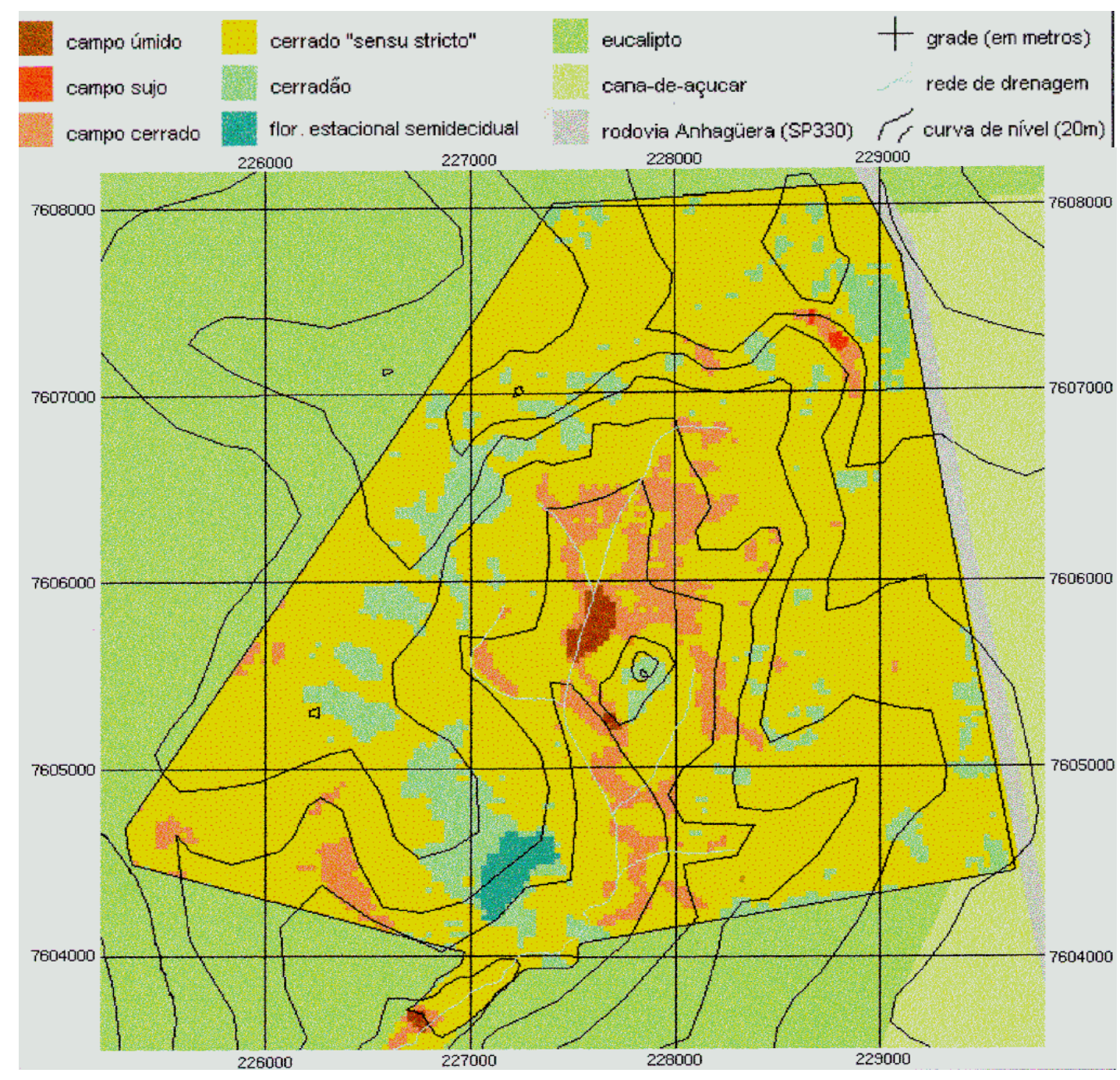

Figura 8 - Distruição das fisionomias na Gleba Pé-de-Gigante, do Parque Estadual de Vassununga. Fonte: Batalha (1997)

O solo é formado predominantemente por Areia Quartzoza e Latossolo Vermelho Amarelo distrófico. Com base em dados climatológicos da estação do DAEE em Santa Rita do Passa Quatro ( $21^{\circ} 42^{\prime} \mathrm{S}, 47^{\circ} 28^{\prime}$ W), a $780 \mathrm{~m}$ de altitude, a região tem uma estação seca de baixos índices de precipitação (menores que $30 \mathrm{~mm}$ ) definida entre Maio e Setembro com umidade relativa média mensal entre 65 e $80 \%$. A torre foi implementada no setor Noroeste da Gleba, a $21^{\circ} 37^{\prime}$ 9'” S, $47^{\circ} 37^{\prime}$ 58'’ W, de forma que as medidas de fluxo turbulento cobrissem um fetch (ou bordadura) de Leste e Nordeste, de onde vem o vento predominante na região. 
Os dados discutidos aqui foram coletados entre 2001 e 2003, sendo que para o ano de 2003 não existem dados de fluxo devido a problemas nos equipamentos.

\subsection{Equipamentos e softwares utilizados}

A Tabela 01 demontra a lista de sensores e equipamentos utilizados em cada um dos sítios experimentais.

Tabela 1 - Sensores usados em cada um dos sítios experimentais

\begin{tabular}{|c|c|c|c|}
\hline Sensor & Variável Observada & $\begin{array}{l}\text { Ecótono Floresta- } \\
\text { Cerrado }\end{array}$ & Cerrado Seco \\
\hline IRGA & {$\left[\mathrm{CO}_{2}\right]$ e $\left[\mathrm{H}_{2} \mathrm{O}\right]$} & Licor 7500 & Licor 6262 \\
\hline Anemômetro Sônico & Vento 3D & CSAT & Gill R2A \\
\hline Perfil de $\mathrm{CO}_{2}$ & {$\left[\mathrm{CO}_{2}\right]$} & CIRAS - Ppsystem & - \\
\hline Respiração do Solo & {$\left[\mathrm{CO}_{2}\right]$} & CIRAS - Ppsystem & EGM2 - Ppsystem \\
\hline Termometros de solo & Temperatura, ${ }^{\circ} \mathrm{C}$ & $2(5 \mathrm{~cm}$ e $20 \mathrm{~cm})$ & $2(5 \mathrm{~cm}$ e $10 \mathrm{~cm})$ \\
\hline Termopares & Temperatura, ${ }^{\circ} \mathrm{C}$ & 10 & - \\
\hline Pluviômetro & Precipitação mm & 1 & 1 \\
\hline FDRs & $\begin{array}{l}\text { Umidade volumétrica, } \\
\qquad \mathrm{m}^{3} \mathrm{~m}^{-3}\end{array}$ & $5 *$ & $8 *$ \\
\hline Psicrômetro & $\begin{array}{l}\text { Temperatura, oC, e } \\
\text { umidade relativa }\end{array}$ & CSI HMP45C & CSI HMP45C \\
\hline Piranômetro & Radiação global, Wm² & Licor - Li200X & Licor - Li200X \\
\hline Radiação PAR & Radiação PAR, Wm² & Licor Quantum & Licor Quantum \\
\hline Saldo Radiômetro & Saldo de radiação $\mathrm{Wm}^{-}$ & REBS & REBS \\
\hline Fluximetro de Solo & $\begin{array}{l}\text { Fluxo de calor no solo, } \\
\qquad \mathrm{Wm}^{-2}\end{array}$ & 5 & 3 \\
\hline Anemoscópio & $\begin{array}{l}\text { Velocidadem } \mathrm{ms}^{-1} \mathrm{e} \\
\text { direção do vento }\end{array}$ & RM YOUNG & RM YOUNG \\
\hline
\end{tabular}

* Os FDRs, no ecótono Floresta-Cerrado, foram instalados a : 0,1; 0,2; 0,5; 1,0; 1,5 e 2.0. No sítio do Cerrado s.s. os FDRs foram instalados a : 0,$1 ; 0,2 ; 0,5 ; 0,8 ; 1,0$; 1,$5 ; 2,0$ e 2,5 .

Os fluxos turbulentos na área do ecótono Floresta-Cerrado foram calculados por um programa desenvolvido por Osvaldo Cabral e os fluxos turbulentos da área do Cerrado s.s. foram calculados por um programa desenvolvido por Jan Elbers. Todos os outros cálulos, além do tratamento dos dados, foram relalizados com programas desenvolvidos pelo próprio autor em Fotran 77/90, utilizando o compilador da Portland 
Group. As figuras, médias móveis e regressões foram feitas utilizando o programa Grapher 3.0. As interpolações de dados foram realizadas com o programa Grads versão 1.8SL11.

\subsection{Indíces de Funcionalidade}

Os indíces de funcionamento adotados neste trabalho foram a eficiência do uso da água, o WUE, e a eficiência no uso da radiação, RUE (Moncrieff et al., 1997 b). A WUE é definida como a razão entre o Fluxo de $\mathrm{CO}_{2}$ e a evapotranspiração. Descreve quantos miligramas de $\mathrm{CO}_{2}$ são assimilados pela superfície para cada uma grama de $\mathrm{H}_{2} \mathrm{O}$ que é evapotranspirada.

Para o cálculo da WUE média diária temos :

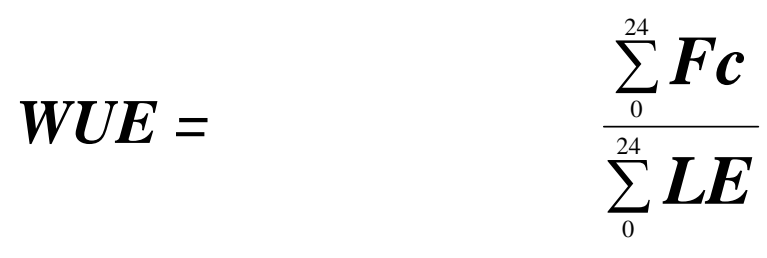

Onde Fc é fluxo de $\mathrm{CO}_{2}$ e e LE é a evapotranspiração.

O RUE é definido como razão entre o Fluxo de carbono e a diferença entre a radiação PAR incidente e refletida. Aponta para o quantos $\mu$ mol de $\mathrm{CO}_{2}$ são assimilados por $\mu \mathrm{mol}$ de fótons absorvidos.

O RUE médio diário é calculado através da equação :

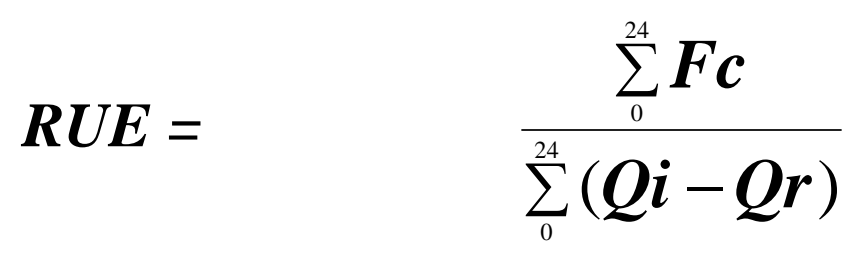

Onde Qi e Qr são a radiação PAR incidente e refletida, respectivamente. 


\section{RESULTADOS E DISCUSSÃO}

\subsection{Cerrado Stricto Sensu}

\subsubsection{Estado da atmosfera à superfície}

O regime de chuvas no período de 2001 a 2003, no Cerrado Stricto Sensu (s.s.), mostrado na Figura 9, foi de modo geral próximo ou um pouco abaixo da média climatológica na estação de Santa Rita do Passa Quatro (1478mm). O ano de 2001 foi o mais seco, com precipitação total de 1170 mm, seguido por 2003 (1239 mm). O ano de 2002 foi o mais chuvoso (1443 mm), e que também mostrou um início mais precoce da estação chuvosa. 


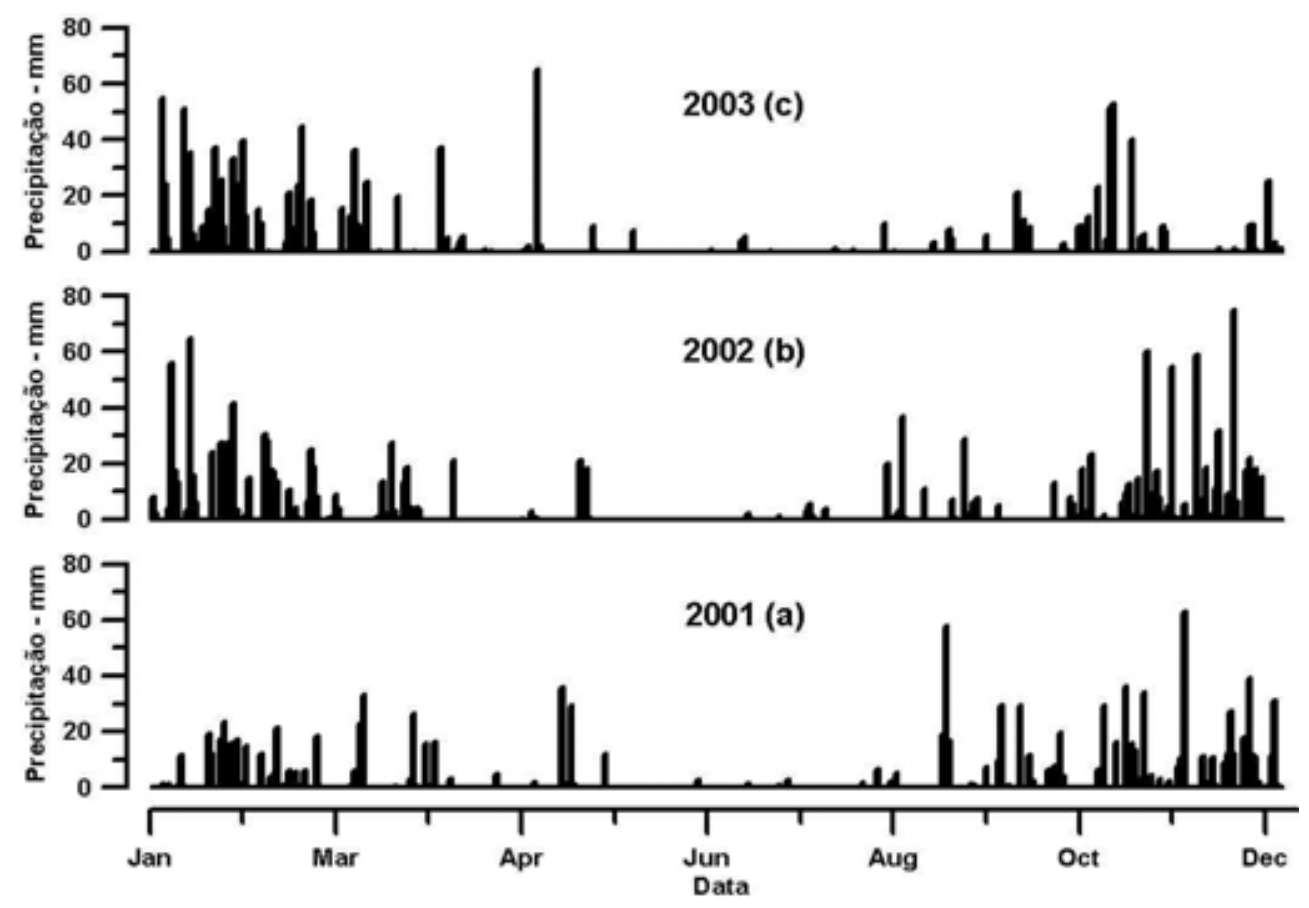

Figura 9- Precipitação acumulada diária no período de 2001(a); 2002(b) e 2003(c), em mm, no Cerrado s.s.

A temperatura média do ar à superfície (Figura 10) foi de $\sim 22{ }^{\circ} \mathrm{C}$ para os três anos. Os valores extremos de temperatura, entretanto, apresentaram uma variação mais substancial. Na temperatura mínima absoluta do ar, houve 13 eventos abaixo de $10,0{ }^{\circ} \mathrm{C}$ em 2001, enquanto em 2002 e 2003 foram, respectivamente, 7 (sete) e 8 (oito). O ano de 2001 foi portanto um ano com mais eventos frios. A umidade relativa média variou, entre os anos, cerca de apenas $1 \%$, sendo a média dos três anos igual a 65\%. O valor mínimo absoluto de umidade relativa no período total foi de $\sim 33 \%$, enquanto que o máximo foi de $93 \%$. 


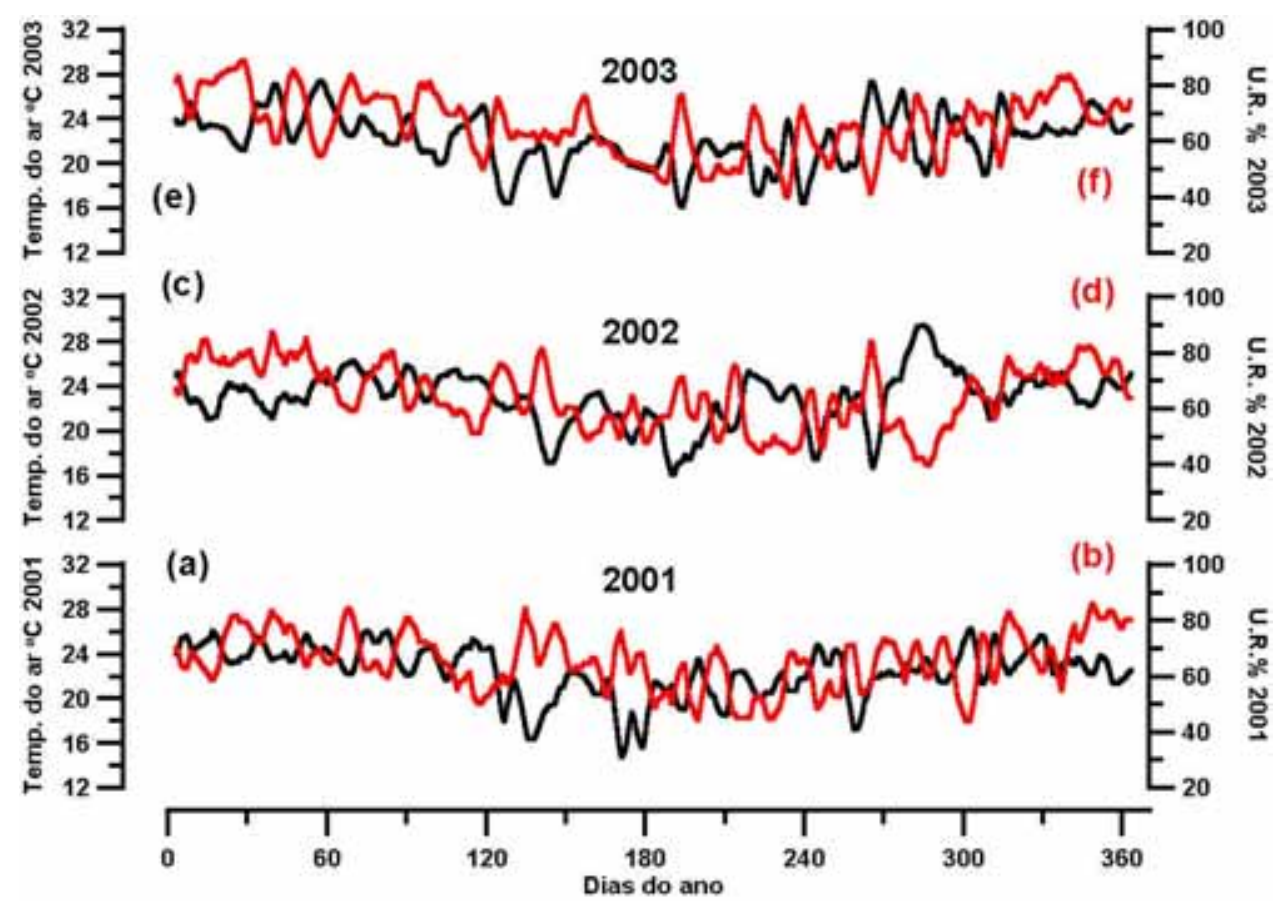

Figura 10 - Média móvel diária observada no Cerrado s.s para: Temperatura média do ar, em ${ }^{\circ} \mathrm{C}$ (linha preta) para o ano de 2001 (a), 2002 (c) e 2003 (e); e Umidade relativa, em \% (linhas vermelhas), para os anos de 2001(b), 2002(d) e 2003 (f)

\subsubsection{Umidade do Solo}

O bioma Cerrado, de forma geral, é encontrado sob solos distróficos e bem drenados (Mota et al., 2002). A observação do tipo de solo sob diferentes áreas de Cerrado tem mostrado diferentes resultados. Em Minas Gerais (Goodland \& Pollard, 1973) encontrou-se um gradiente nutricional entre as fisionomias de Cerrado e também da concentração de alumínio. No planalto central, as evidências de solo sob Cerrado s.s. e sob Cerradão mostram que as concentrações de nutrientes são similares, mas a quantidade de alumínio é maior no Cerradão (Haridasan, 1992).

As observações reportadas na área da Gleba Pé de Gigante mostram altos valores de alumínio, mas não diferenças significativas na fertilidade do solo e no teor de argila, sob as manchas fisionômicas. A fertilidade não mostrou ser um determinante de 
fisionomias naquela área (Ruggiero et al., 2002). Poderia-se supor, a princípio, que não existe diferença substancial na capacidade de retenção de água na extensão de toda a gleba, uma vez que esta dependeria em grande parte da quantidade de argila no solo (Bruno, 2004).

O déficit hídrico do solo causa a liberação de um hormônio vegetal nas folhas, o ácido abscísico (ABA), que induz a senescência das folhas de muitas espécies (Larcher, 2000). Porém, devido ao solo bem drenado, frequentemente arenoso, as raízes das espécies arbóreas de Cerrado encontram facilidade para atingir níveis mais profundos, chegando até o lençol freático. Isso promoveria um suprimento parcial de água para a manutenção da biomassa verde, mesmo durante o período seco. Já foram encontradas raízes de plantas de Cerrado a 18 metros de profundidade (Rawitcher, 1948).

O trimestre de verão (Jan-Fev-Mar) em 2002 mostrou um solo mais úmido, comparado ao mesmo período de 2001 (Figs. 11 e 12). Por outro lado, a duração da fase seca, se observado do ponto de vista da umidade do solo, foi maior durante 2002, visto que as primeiras chuvas da estação úmida, em setembro de 2002, não foram suficientes em quantidade e regularidade, para recarregar o solo até a profundidade de 2,5 m (Figura 12), o que de certa forma ocorreu em 2001 já em meados de setembro. 


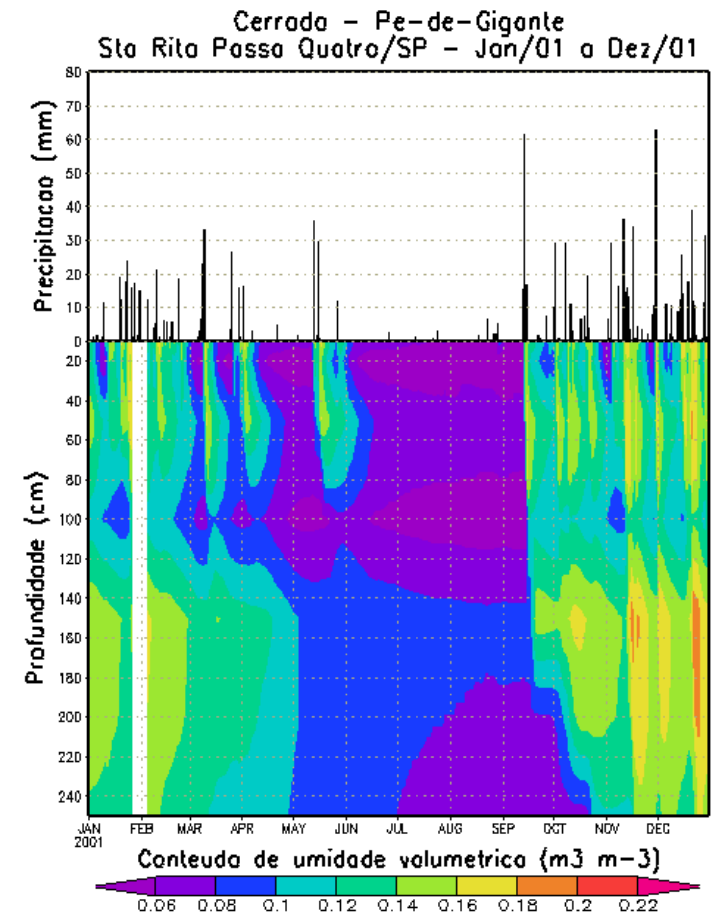

Figura 11 - Precipitação acumulada diária, em mm, superior; e umidade volumétrica até $240 \mathrm{~cm}$ de profundidade, do Cerrado Seco, em $\mathrm{m}^{3} \mathrm{~m}^{-3}$, para o ano de 2001. Fonte: Bruno (2004)

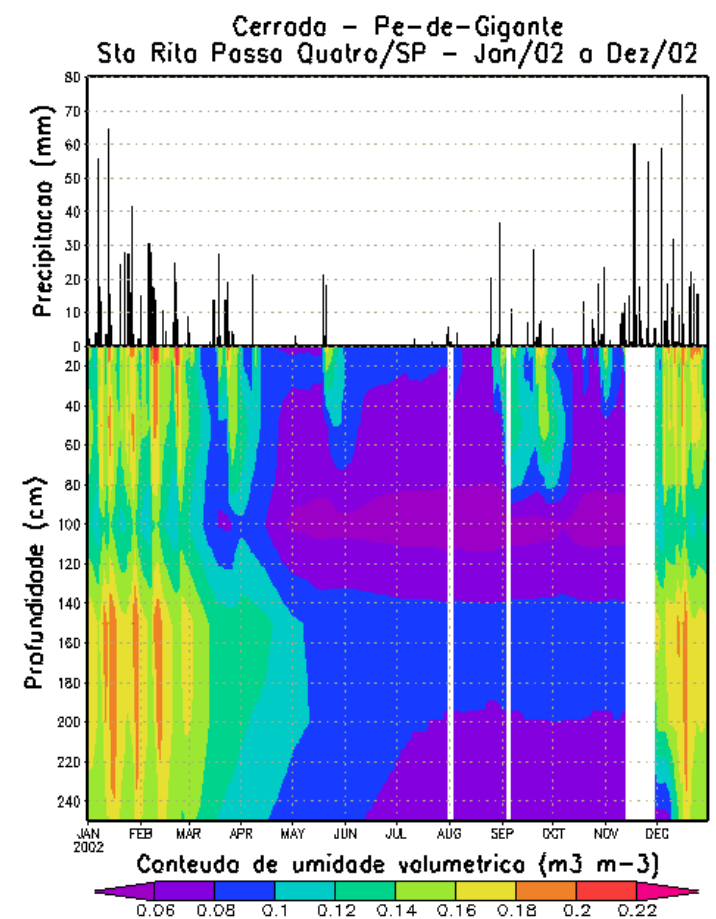

Figura 12 - Precipitação acumulada diária, em mm, superior; e umidade volumétrica até $240 \mathrm{~cm}$ de profundidade, do Cerrado Seco, em $\mathrm{m}^{3} \mathrm{~m}^{-3}$, para o ano de 2002. Fonte: Bruno (2004)

Isto corrobora os resultados de umidade relativa média (Figura 10), que é mais alta, de forma regular, no início da estação úmida de 2001, enquanto em 2002 há uma certa flutuação. Esta comparação sugere que a umidade do solo observada reflete razoavelmente as condições médias de variabilidade da atmosfera sobre a área experimental, e não seria uma estimativa pontual e tendenciosa pelo fato de haver apenas um perfil de medição. Apesar da grande profundidade que as raízes de algumas árvores de Cerrado podem alcançar, a maior parte das raízes tem uma distribuição mais superficial. Castro \& Kauffman (1998) reportam que 31\% da biomassa subterrânea está nos primeiros $10 \mathrm{~cm}$ de solo, $71 \%$ até $30 \mathrm{~cm}$, e abaixo de 1 metro há de 3 a 4 \%. Devido à matéria orgânica presente na superfície do solo, a maior parte dos nutrientes se concentra na camada mais superficial. Assim, observa-se uma relação morfológica- 
funcional, onde a maior parcela se distribui na superfície para absorver a maior quantidade de nutrientes possíveis e uma parcela menor cresce em direção ao lençol freático em busca de água.

\subsubsection{Radiação}

O padrão da radiação fotossintéticamente ativa (PAR) incidente segue um ciclo sazonal bem definido, com máximos no solstício de verão e mínimos no de inverno, ao longo do período de 2001 a 2003 (Figura 13). Também, de forma nítida, ocorrem flutuações devido à nebulosidade. Os valores medidos foram calibrados (Apêndice 3).

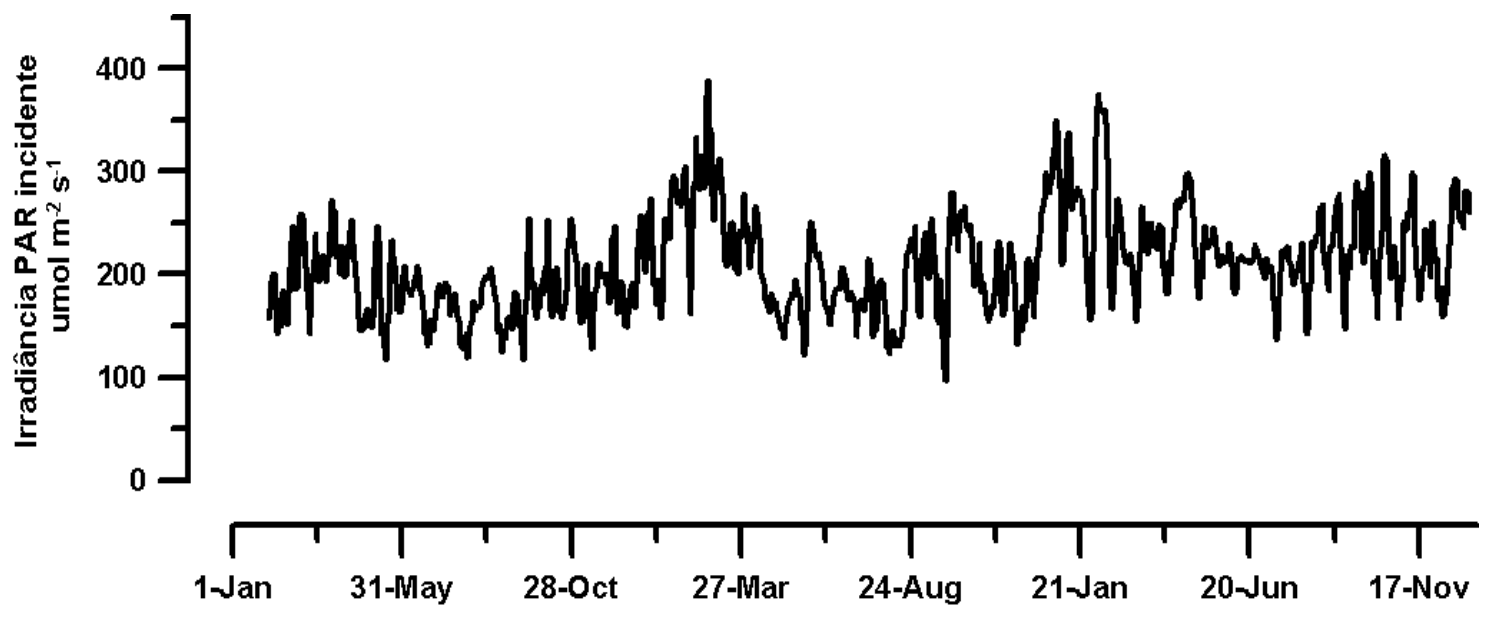

Figura 13 - Média (móvel) diária da irradiância PAR incidente no Cerrado s.s., para o período de 2001, 2002 e 2003, em $\mu$ mol PAR $\mathrm{m}^{-2} \mathrm{~s}^{-1}$

O Albedo-PAR, definido como a razão entre a irradiância PAR refletida sobre a incidente, segue teoricamente uma proporção inversa de variação com a quantidade de biomassa verde na vegetação. Ou seja, o aumento da fração de folhas verdes aumenta a absortância na faixa eletromagnética do visível (utilizado na fotossíntese) e consequentemente reduz a refletância e o Albedo-PAR.

A variabilidade observada do Albedo-PAR médio diário no Cerrado s.s. (Figs. 14 e 15) oscila entre aproximadamente $2 \%$ a $6 \%$, e sugere outras informações importantes. A primeira é a variabilidade interanual e a segunda é a variação sazonal entre as fases 
seca e chuvosa. Para os três anos reportados, o aumento do Albedo-PAR começa a ocorrer entre o fim de março e o início de abril. Pode-se supor desta forma que nesta época surgiriam os primeiros sinais de redução da atividade fotossintética no sistema. Apesar de se observar ainda uma quantidade substancial de chuva em março e abril, é nesta época onde surgem os primeiros veranicos, períodos de vários dias com supressão da precipitação. Nestes eventos já se observou, em 2001 e 2002, que a umidade do solo foi marcada com pulsos secos até $\sim 130 \mathrm{~cm}$ de profundidade (Figs 11 e 12), intermediados por pulsos úmidos. Este padrão não ocorreu durante o trimestre chuvoso Dez-Jan-Fev, e pode ser apontado como um dos mecanismos candidatos a explicar o disparo do aumento do Albedo-PAR. Isto não deveria subentender que houve categoricamente uma mudança drástica na coloração das folhas, mas que sugestivamente já surgiram os primeiros sinais do processo de senescência das folhas e/ou de dormência das gramíneas no final da estação chuvosa, decorrente dos veranicos e das anomalias secas da umidade do solo. Como o estrato herbáceo tem o sistema radicular mais raso, seria de se suspeitar que este efeito se manifestasse mais obviamente neste componente. Por outro lado, como a cobertura da copa das árvores no final da estação chuvosa ainda não foi reduzida, o efeito do estrato herbáceo nos sensores de radiação teria menor intensidade, ou em outras palavras, as mudanças no estrato arbóreo controlariam em maior proporção o albedo medido durante a estação chuvosa. Deixa-se, desta forma, um ponto aberto na discussão, o de que as mudanças poderiam também estar se manifestando em todos os estratos (arbóreo, arbustivo e herbáceo). 


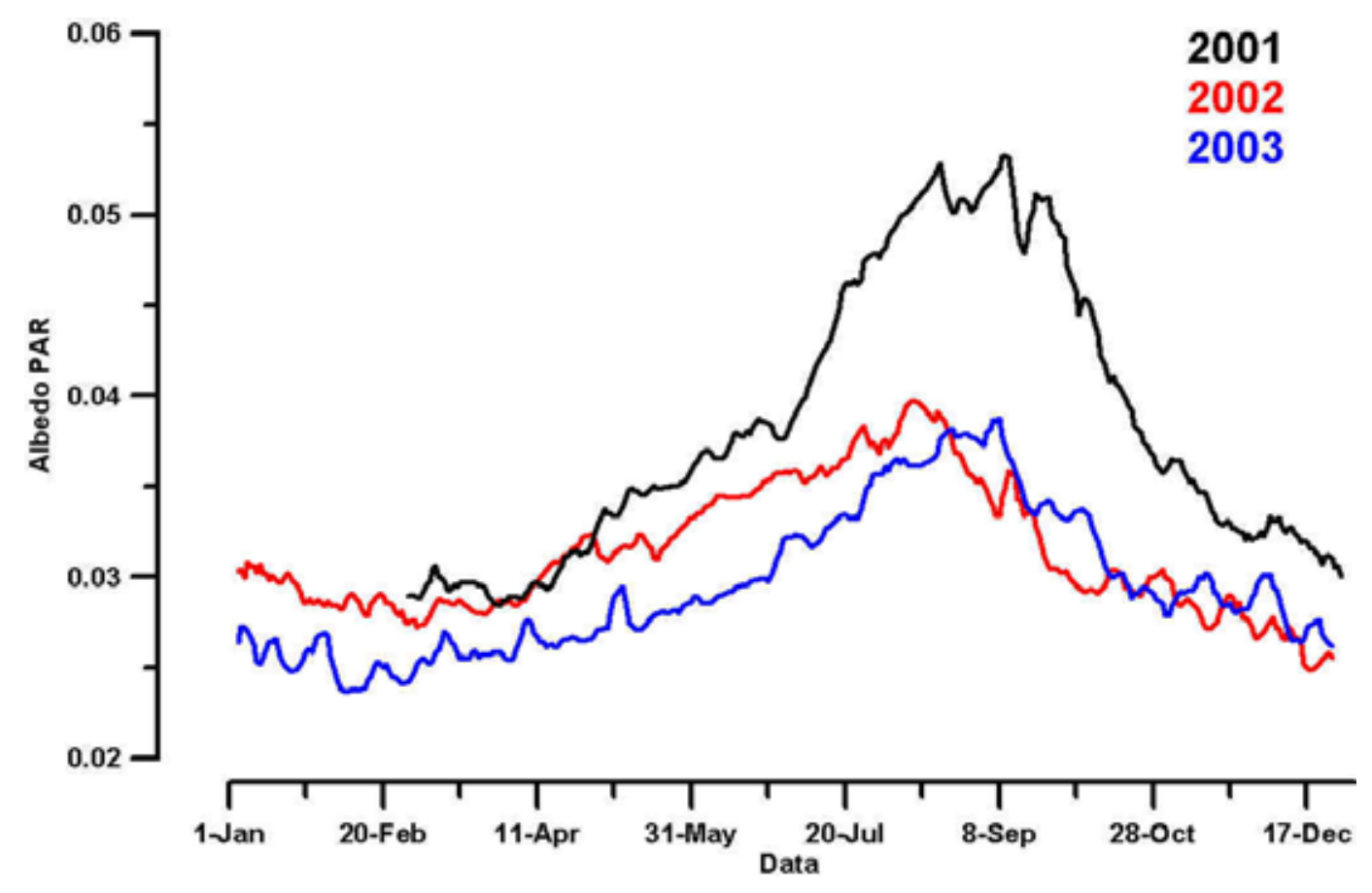

Figura 14 - Médias (móveis) diárias do Albedo-PAR para o Cerrado s.s. ao longo dos anos: 2001, em preto; 2002, em vermelho; 2003, em azul

Dentro das variáveis medidas experimentalmente, os valores observados extremos do Albedo-PAR podem ser controlados pela disponibilidade hidrica e pela variação de temperatura (Figura 15). O mais alto valor do Albedo-PAR máximo anual observado, em 2001 (7,4\%, veja Tabela 2), comparado com os outros anos (4,1\% em 2002 e em 2003), sugere que tenha sido resultante de uma redução das atividades fisiológicas da vegetação relativamente mais intensa naquele ano. Em outras palavras, concorre para um mínimo de absorção de radiação fotossintéticamente ativa pela vegetação, corrlacionado com um mínimo de biomassa verde. A mesma variabilidade interanual do albedo máximo refletiu-se no albedo médio anual (Tabela 2), ou seja, em 2001 o albedo foi superior aos demais anos. 


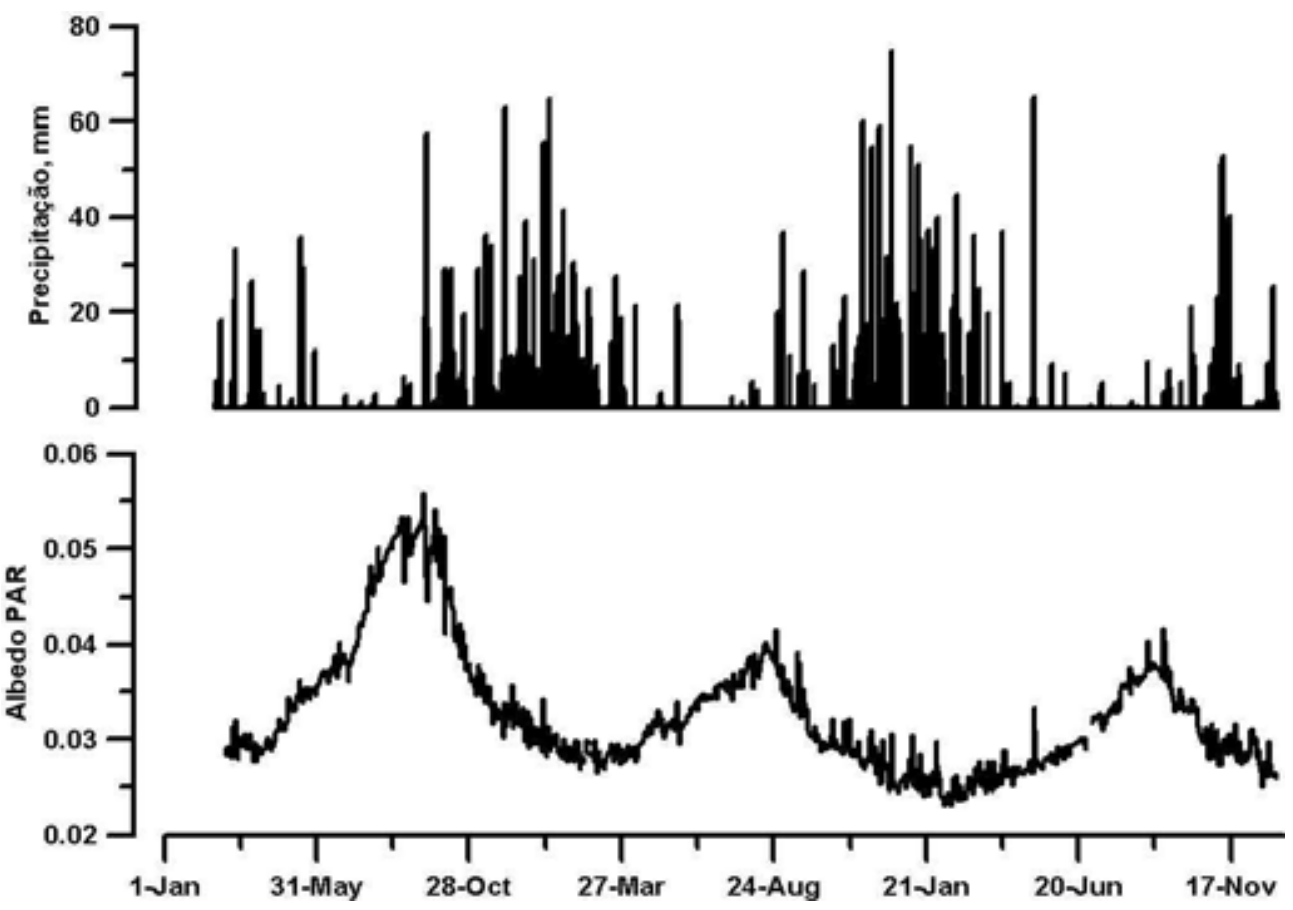

Figura 15 - Precipitação diária (a) e médias diárias do Albedo-PAR (b), ao longo dos anos de 2001, 2002 e 2003. Para o sítio experimental do Cerrado s.s.

São dois os possíveis controles do albedo-PAR máximo no inverno, de que temos disponibilidade de dados: a umidade do solo, e o número e intensidade de eventos frios. Na transição da estação seca para chuvosa notamos notáveis diferenças entre os anos observados, durante esta época.

O trimestre chuvoso Jan-Fev-Mar, antecedente ao evento do máximo do AlbedoPAR, foi claramente mais seco em 2001, comparado com os demais anos (Figura 15). No entanto, na transição da estação chuvosa para seca (Mar-Abr-Mai), a umidade do solo foi muito similar em 2001 e em 2002. Isto sugere que, pelo menos quanto à umidade do solo, a diferença entre o albedo-PAR máximo entre 2001 e 2002, tenha tido pouca influência da umidade do solo.

A temperatura é o segundo fator que levantamos como um dos indutores de senescência e dormência. Isto explicaria que as frentes frias seriam também responsáveis pela modificação do estado do ecossistema durante o período de inverno, a ponto de influenciar na variabilidade interanual. Rigorosamente, o número de eventos frios, a sua 
intensidade, e a fase do ano em que ocorrem, montariam um arcabouço completo para a análise da influência desta variável no albedo.

Em 2001, no período de Mai-Jun, que corresponde à transição da estação secachuvosa e o início do Inverno, o número de eventos frios (abaixo de $11^{\circ} \mathrm{C}$ ) foi maior do que os demais anos (Tabela 2). Particularmente comparado com o ano de 2002, a frequência de eventos frios foi bastante superior naquela época. Esta observação é uma evidência de que a temperatura mínima possa ter controlado o albedo-PAR e explicado a variabilidade interanual. No decorrer do inverno, todavia, em 2002 sucederam-se novos eventos frios. No entanto, não se observou correspondência de resposta de aumento do albedo à esta variabilidade, pelo menos nos anos de 2001 e 2002.

Os eventos frios foram contabilizados tomando-se a temperatura mínima absoluta de $11^{\circ} \mathrm{C}$, medida a $22 \mathrm{~m}$ de altura. É possível que a temperatura do ar mínima, na altura média da copa da vegetação na área ( 10 m) seja inferior, uma vez que à noite há uma notável inversão do perfil. Isto mostra que o impacto sugerido não deve ser analisado com relação à temperatura de forma absoluta.

Tabela 2 - Albedo-PAR mínimo no trimestre chuvoso Jan-Mar, máximo no trimestre Jul-Set, e médio anual. Número de eventos frios correspondem ao número de dias com temperatura mínima do ar (medida a $22 \mathrm{~m}$ de altura) abaixo de $11^{\circ} \mathrm{C}$, para os anos de 2001, 2002 e 2003, no Cerrado s.s.

\begin{tabular}{cccccc}
\hline Ano & $\begin{array}{c}\text { Albedo } \\
\text { mínimo no } \\
\text { trimestre } \\
\text { Jan-Mar }\end{array}$ & $\begin{array}{c}\text { Albedo } \\
\text { máximo no } \\
\text { trimestre } \\
\text { Jul-Set }\end{array}$ & $\begin{array}{c}\text { Albedo } \\
\text { médio } \\
\text { anual }\end{array}$ & $\begin{array}{c}\mathrm{N}^{\mathbf{0}} \\
\text { eventos } \\
\text { frios } \\
\text { (Mai-Jun) }\end{array}$ & $\begin{array}{c}\mathrm{N}^{\mathbf{0}} \text { eventos } \\
\text { frios (Jul- } \\
\text { Ago) }\end{array}$ \\
\hline 2001 & 0,027 & 0,074 & 0,047 & 4 & 0 \\
2002 & 0,027 & 0,041 & 0,031 & 2 & 2 \\
2003 & 0,023 & 0,041 & 0,029 & 3 & 3 \\
\hline
\end{tabular}

Os valores mínimos de Albedo-PAR são bastante próximos para os três anos de observação (Figura 15). Isto indica que a vegetação retornaria para um estado funcional de máximo funcionamento durante o período chuvoso, indicando haver uma faixa máxima de absorção de radiação visível. Detalhadamente, o albedo mínimo no trimestre 
chuvoso Jan-Mar em 2003 foi, em valor absoluto, ligeiramente menor que os demais anos (Tabela 2). Uma possível explicação para este fenômeno seria a existência de um efeito de memória do sistema em relação as chuvas. Ou seja, o ano de 2003 estaria sendo beneficiado por um estado mais favorável ao funcionamento no ano de 2002, que por sua vez se seguiu a um ano menos favorável, em 2001. Para a biomassa de campos de savana com estrato herbáceo na África foi reportada uma dependência com a estação chuvosa dos anos anteriores (Wiegand et al., 2004). Isto indica que o sistema, ou a vegetação, guarda um registro ou memória sobre as chuvas dos anos anteriores, e utiliza esta informação no investimento de recursos, no caso para a produção de biomassa verde e, consequentemente, de fotossíntese. Este mecanismo poderia estar ocorrendo no Cerrado s.s. deste estudo, ou seja, o sistema estaria guardando uma memória das condições ambientais do ano anterior. Para uma análise mais profunda, é necessário um período de análise na escala decadal, o que ainda está além do escopo deste estudo.

\subsubsection{Fluxos de superfície}

Os fluxos de energia (calor sensível e calor latente), medidos pela técnica da correlação dos vórtices turbulentos, são apresentados na Figura 16. O fechamento do balanço de energia foi satisfatório, e as correções de Webb e Riehl mostraram-se importantes na estimativa de valores mais realistas dos fluxos (Apêndices 1 e 2). Uma descrição da direção do vento e condições turbulentas nas áreas experimentais encontrase no Apêndice 4.

De forma geral, os fluxos de energia são proporcionais ao saldo de radiação e portanto da irradiância solar PAR, que foi discutida previamente. A proporção e dependência da energia solar verifica-se tanto na escala do ciclo diurno como na escala sazonal. Em ecossistemas brasileiros isto foi reportado detalhadamente com medidas micrometeorológicas na cana-de-açúcar (Rocha, 1998; Cabral, 2003), no Cerrado s.s. (Rocha et al., 2004a; Juarez, 2004) e na floresta tropical amazônica (Rocha et al., 2004). Entretanto, com a redução da precipitação, a umidade do solo reduz, o que conduz a um maior estresse hídrico, que, por sua vez, irá induzir a senescência das folhas e dormência 
das gramíneas. Assim, a menor precipitação reduz a evapotranspiração e aumenta a exposição do solo à radiação incidente.

Os valores mínimos do fluxo de calor latente alcançam mínimos no auge da estação seca, entre agosto e setembro, com valores entre 20 a $40 \mathrm{Wm}^{-2}$ (Figura 16). Isto corresponde a aproximadamente 0,7 a 1,1 $\mathrm{mm} \mathrm{dia}^{-1}$ de evapotranspiração, o que já indica que a vegetação mantinha, em substancial proporção, parte do seu funcionamento fotossintético em atividade mesmo nos períodos de estresse hídrico avançado.

O fluxo de calor sensível, por sua vez, tem um padrão de variação sazonal de proporção inversa à radiação solar, ou seja, aumenta no inverno e reduz-se no verão (Figura 16). Na transição da estação seca para a chuvosa, quando há redução da energia solar, observa-se a redução concomitante tanto do fluxo de calor sensível como do latente. Mas com o progresso do período seco, o fluxo de calor sensível tende a aumentar. Isto significa que o controle do estado do ecossistema do Cerrado s.s. é predominante na variabilidade do fluxo de aquecimento do ar. Na escala sazonal, a flutuação do fluxo de calor sensível ocorre em média no intervalo entre 10 e $70 \mathrm{~W} \mathrm{~m}$.2. 


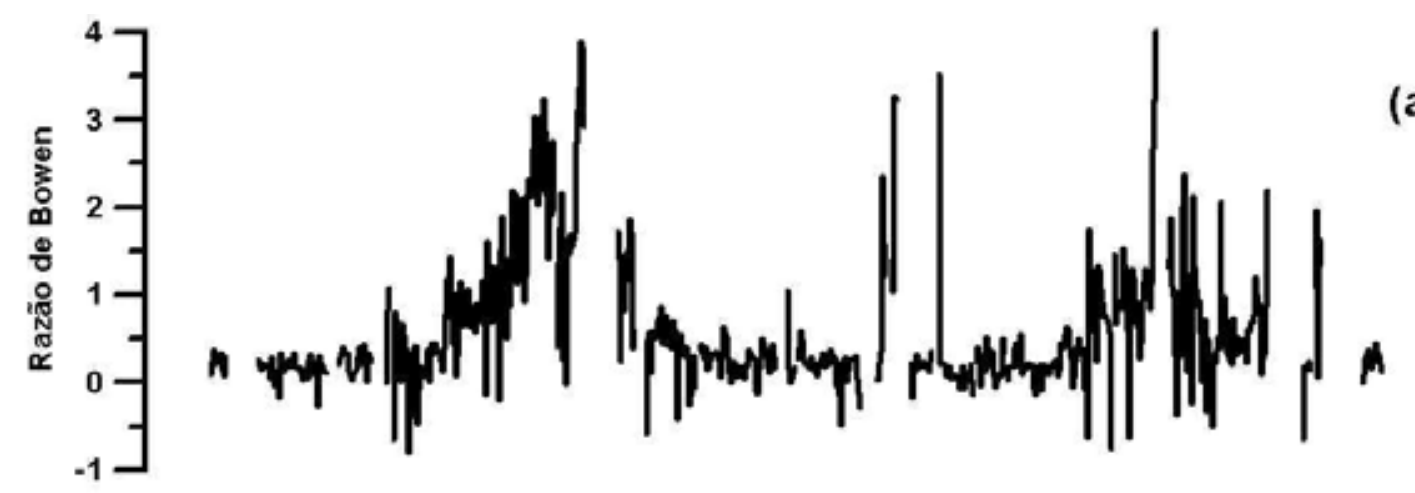

(a)

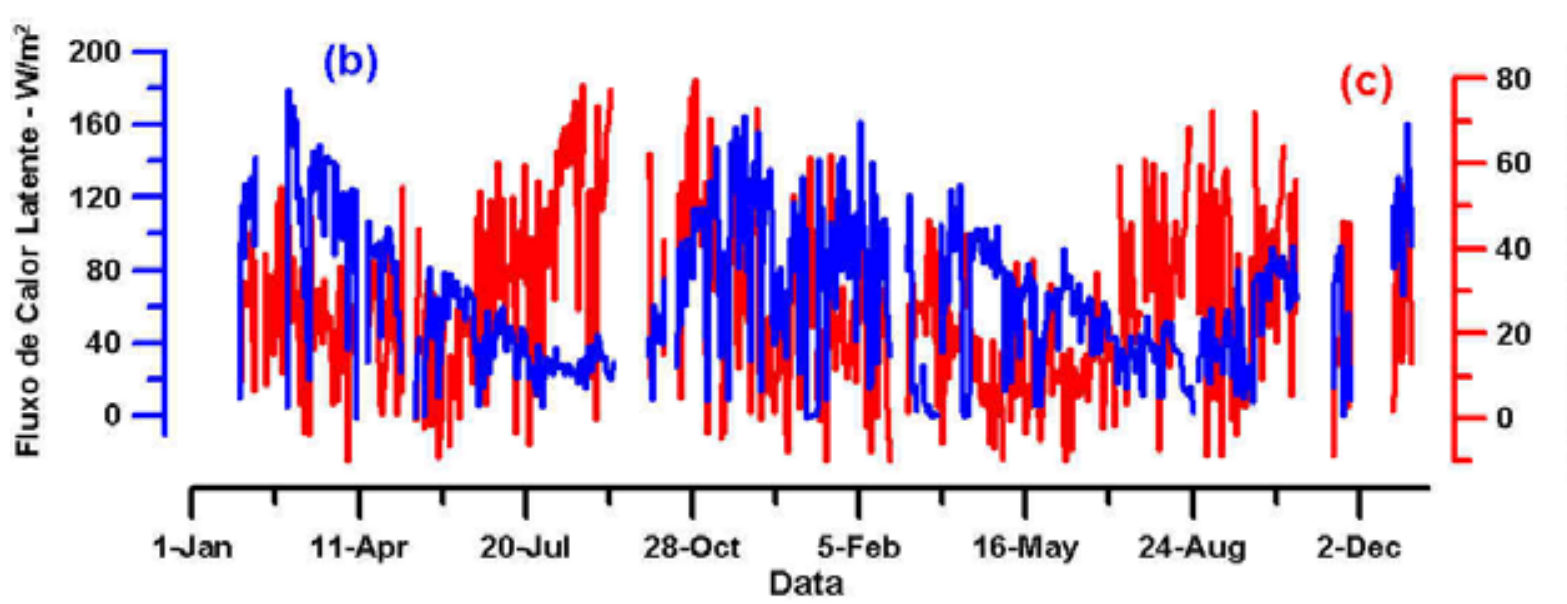

Figura 16 - Fluxos de energia e partição de energia para o Cerrado s.s. para o período de 2001 e 2002: (a) Média diária de Razão de Bowen; Média móvel diária do Fluxo de Calor sensível (c), (linha vermelha); e Fluxo de calor Latente (b) (linha azul), em $\mathrm{W} \mathrm{m}^{-2}$

Desta forma a razão de Bowen (Figura 16a) tem um padrão notavelmente dependente da sazonalidade entre o período chuvoso e o período seco. A partição de energia no período seco indica muito pouca disponibilidade de água no ecossistema (razão de Bowen alta). No período úmido, por sua vez, a razão de Bowen é mínima, mais estacionária, variando aproximadamente entre 0,2 e 0,3.

Na escala interanual, durante a estação seca, em 2001 o fluxo de calor sensível mostrou-se superior aos valores medidos em 2002 (Fig. 16 b,c). Concorrentemente, o fluxor de calor latente também foi levemente superior em 2002, durante o período seco, comparado com 2001 (Fig. 16b,c). Assim, durante a fase seca, os valores da razão de Bowen foram mais altos para 2001 do que para 2002, por causa do estado do ecossistema. Isto ocorreu, em parte, devido à diferença no regime de precipitação. 
A análise da variação interanual da razão de Bowen mostrou-se de todo comparável com a análise da variabilidade do Albedo-PAR. Ou seja, o ano de 2001 mostrou um estado da vegetação com menor funcionamento fotossintético durante o período seco. É importante ressaltar é que o Albedo-PAR é uma medida pontual, de abrangência na ordem de grandeza de $10 \mathrm{~m}$, enquanto que a razão de Bowen e os fluxos turbulentos são na ordem de $1 \mathrm{~km}$. Portanto mostra-se oportuno o fato do conjunto de medidas comporem uma informação ampla e coerente da variabilidade do ecossistema.

\subsubsection{Fluxos turbulentos de $\mathrm{CO}_{2}$}

As medidas de fluxos atmosféricos de $\mathrm{CO}_{2}$ para o Cerrado previamente reportadas (Rocha et al., 2002; Vourlitis et al., 2001; Miranda et al., 1997) mostraram que o ecossistema possui uma alta sazonalidade da fixação de $\mathrm{CO}_{2}$. Durante o período chuvoso ocorre assimilação de carbono, caracterizando o sistema funcionalmente como sumidouro. Durante a fase seca, ocorre uma inversão do sinal, caracterizando assim um período de perdas de $\mathrm{CO}_{2}$ para a atmosfera.

O fluxo total de $\mathrm{CO}_{2}$ (Figura 17a) observado no Cerrado s.s. corrobora os padrões descritos na literatura. Durante o período seco, tanto de 2001 como de 2002, ocorre uma inversão do funcionamento do ecossistema, fazendo com que o ecossistema perca $\mathrm{CO}_{2}$ para atmosfera.

Os fluxos turbulentos noturnos de $\mathrm{CO}_{2}$, uma medida proxi da respiração do ecossistema (Figura 17 b), são também importantes indicadores do estado fisiológico da vegetação. Pode-se observar uma variação sazonal, com a respiração média diária chegando a variar de $0,75 \mu \mathrm{mol} \mathrm{CO}_{2} \mathrm{~m}^{-2} \mathrm{~s}^{-1}$ no auge da estação seca, para até valores superiores a $5 \mu \mathrm{mol} \mathrm{CO} \mathrm{m}^{-2} \mathrm{~s}^{-1}$ no auge da estação chuvosa (Figura 17c). O ciclo anual de temperatura e de radiação (Figs. 17d e 10) favorece a redução da atividade metabólica durante o período seco, uma vez que este coincide com o inverno. A menor disponibilidade hídrica tem como efeito direto a diminuição da atividade metabólica, provocada pelo fechamento estomático e pela redução das atividades fisiológicas da planta. Como efeito indireto, estimularia a liberação do ABA, que por sua vez levaria a 
senescência, reduzindo a fotossíntese e a evapotranspiração. Com uma quantidade reduzida de biomassa verde, o funcionamento fisiológico do ecossistema é reduzido. Caracteriza-se portanto uma diminuição da taxa metabólica de respiração autotrófica, mas que também é concorrente com a diminuição da decomposição da matéria orgânica, devido à redução de umidade e de temperatura (Figura 10). Tanto a respiração heterotrófica como a autotrófica compõem a medida do fluxo turbulento noturno, mostrando-se aparentemente presentes no sinal. Uma discussão da variabilidade sazonal da respiração do solo no Cerrado s.s. com medidas de câmaras de solo é reportada em Rocha et al., (2002), e mostrou uma variabilidade sazonal com um padrão muito similar.

$\mathrm{O}$ padrão dos fluxos diurnos de $\mathrm{CO}_{2}$ (Figura 17c) provê um bom indicador da produtividade do sistema, mostrando-se, como a respiração, dependente dos períodos de seca e da disponibilidade de água. Com mais água, os estômatos estão mais abertos, há maior troca gasosa, maior produção de biomassa verde e conseqüentemente maior produtividade primária do ecossistema. No período diurno, o Cerrado s.s mostrou taxas de $\sim 9 \mu \mathrm{mol} \mathrm{CO}_{2} \mathrm{~m}^{-2} \mathrm{~s}^{-1}$ de assimilação durante o auge da fase chuvosa, entre 20012002. Para o período seco, houve uma diferença de mais de $100 \%$ nas médias diurnas do fluxo de $\mathrm{CO}_{2}$, quando comparados os anos de 2001 e 2002. Esta variação percentual não é surpreendente principalmente porque as perdas absolutas são de pequena grandeza. Para 2002, os valores diurnos médios do fluxo de $\mathrm{CO}_{2}$ alcançaram $\sim 1,5 \mu \mathrm{mol} \mathrm{CO}_{2} \mathrm{~m}^{-2} \mathrm{~s}^{-}$ ${ }^{1}$. Em 2001 estes valores foram $\sim 0,7 \mathrm{CO}_{2} \mu \mathrm{mol} \mathrm{m}^{-2} \mathrm{~s}^{-1}$, apontando mais uma vez para o efeito que a diferença interanual do estado do ecossistema mostrou durante o período seco. 


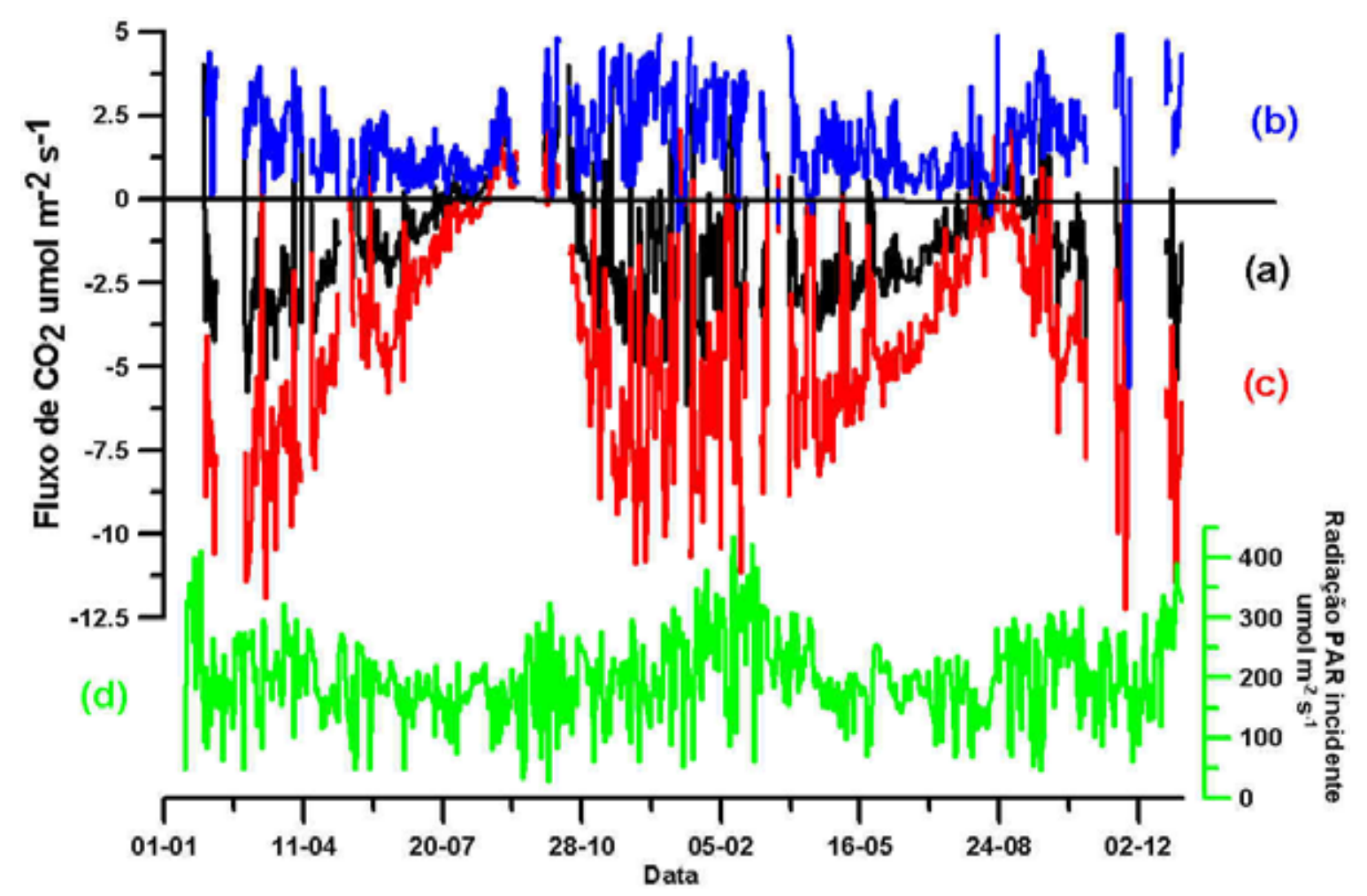

Figura 17- Médias diárias de Fluxo de $\mathrm{CO}_{2}$, em $\mu \mathrm{mol} \mathrm{CO} \mathrm{CO}_{2} \mathrm{~m}^{-1}$, para os anos de 2001 e 2002. (a) Fluxo total (linha preta) ; (b) Fluxo noturno (linha azul) ; (c) Fluxo diurno (linha vermelha); (d) Radiação PAR inicidente. Para o sítio experimental do Cerrado s.s.

$\mathrm{O}$ efeito do estado da vegetação nos fluxos totais de $\mathrm{CO}_{2}$ é evidenciado na comparação entre os anos de 2001 e 2002 (Figura 18). Em ambos os casos, houve um período de perdas no final da estação seca, ou em outras palavras, quando a fotossíntese diária não foi o suficiente para compensar algebricamente a respiração da vegetação e a oxidação da matéria orgânica. Como ressalta a comparação interanual das perdas de carbono no fim do período seco, o valor absoluto das perdas também acompanha-se do aumento da extensão do período em que o ecossistema perde $\mathrm{CO}_{2}$. Em uma primeira instância, uma vez que maiores perdas resultam de um estado de funcionamento fotossintético mais depreciado, demandaria-se mais tempo para se recompor com o início das chuvas. Isto parece lógico, embora se desconheça alguma referência mostrando isto de forma quantitativa para os cerrados. 


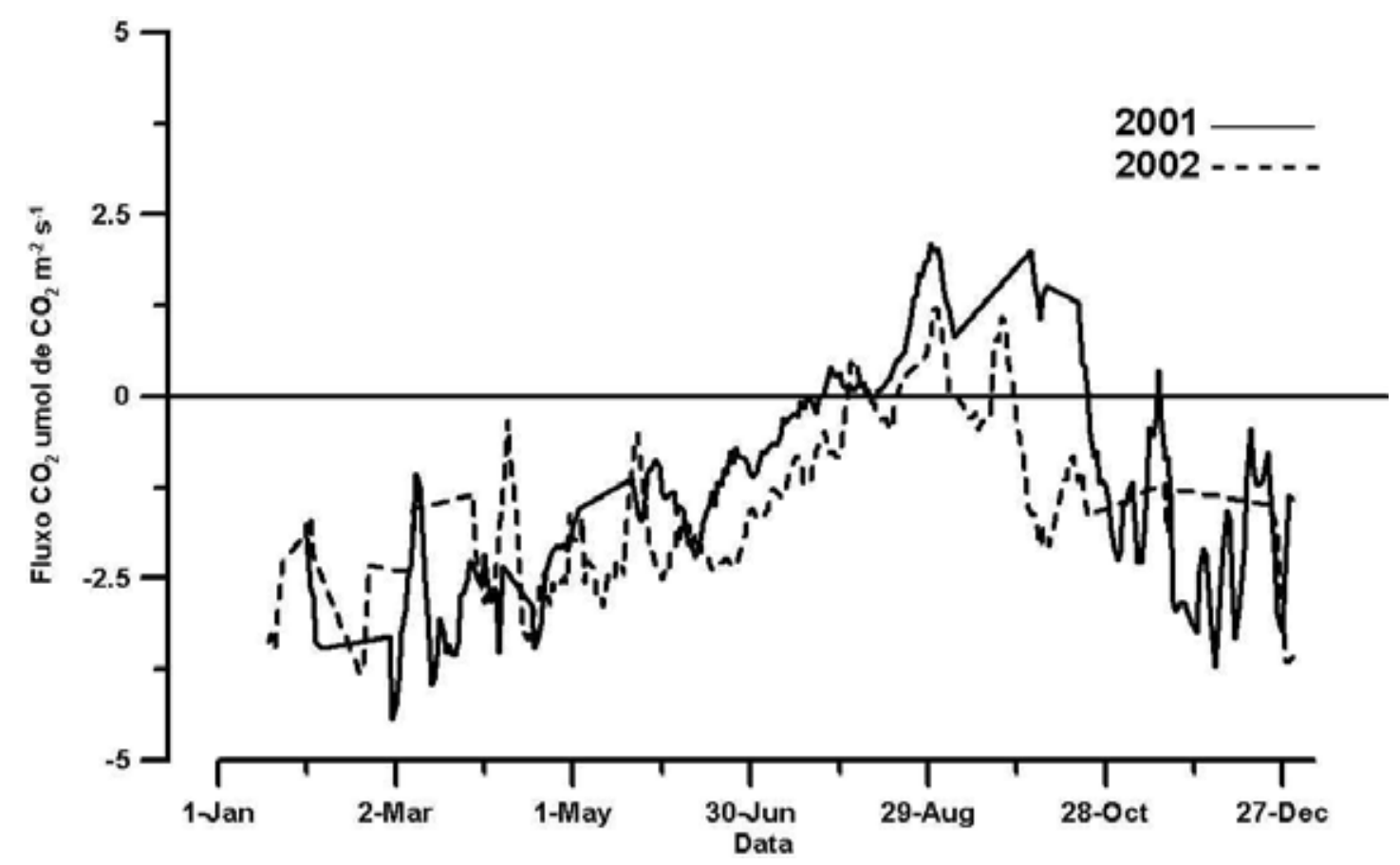

Figura 18- Média (móvel) diária para o fluxo de $\mathrm{CO}_{2}$ em $\mu \mathrm{mol} \mathrm{CO}_{2} \mathrm{~m}^{-2} \mathrm{~s}^{-1}$, para o ano de 2001, (linha preta); e para o ano de 2002 (linha vermelha), no sítio experimental do Cerrado s.s.

\subsection{Ecótono Floresta-Cerrado}

A inundação é um fenômeno recorrente e característico da região do sítio experimental do ecótono Floresta-Cerrado, na região da Ilha do Bananal. Sendo assim, espera-se que a vegetação local tenha sido selecionada para sobreviver a esta variável ambiental, apresentando diferentes níveis de resistência e adaptação à inundação.

De forma geral, os diferentes regimes ambientais favorecem grupos distintos de espécies. Nas áreas de ecótono a existência de um bioma em detrimento de outro é determinado pelas condições microclimáticas, como também as do solo e da topografia (Walter, 1970). No sítio experimental do ecótono Floresta-Cerrado suspeita-se que o controle predominante seja topográfico, ou seja, pequenas diferenças de cota topográfica, entre 1 a $5 \mathrm{~m}$, promoveriam diferenças na profundidade do lençol freático e conseqüentemente nos diferentes regimes de inundação e aeração do solo. Isto pode eventualmente ter um papel chave no controle dos biomas nas áreas alagáveis. Em áreas 
alagáveis no domínio dos Cerrados, como no Mato Grosso, as áreas um pouco mais elevadas favorecem as formações árboreas de Cerrado, enquanto que as depressões favorecem os campos de gramíneas (Araujo Neto et al., 1986). O mesmo padrão é encontrado entre a transição de Floresta-Cerrado na Ilha de Maraça, no Acre (Furley \& Ratter, 1990). No bioma dos Cerrados, a diferenciação das fisionomias poderia ocorrer devido às diferenças pedológicas, associadas ao tipo de solo (por exemplo o contraste entre o Latossolo vermelho, mais argiloso e com mais nutrientes, e a Areia quartzosa), ou ao impedimento de placas lateríticas próximas à superfície, que reduziriam substancialmente a capacidade de retenção de água e limitariam o crescimento do sistema radicular.

A inundação tem um efeito diferencial nos biomas. Nos Cerrados chamados de hipersazonais existem quatro períodos funcionais distintos. Um ciclo distinto ocorre durante a inundação, o outro durante a fase seca, e as respectivas transições (Sarmiento, 1984). Sabe-se que nas florestas de terra firme, como por exemplo a Floresta Amazônica, as espécies apresentam um crescimento sazonal, demonstrado pelos anéis de crescimento, com maior crescimento no período chuvoso. Nas áreas alagáveis, entretanto, o crescimento ocorre durante o período seco ou não inundado, concentrandose prioritamente logo após a inundação (Dezzeo et al., 2003; Junk, 1991).

A data mais provável da inundação da área experimental, no ponto da base da torre , foi em 03/02/2004. Porém, devido ao relevo suave mas significativo ( 0,5 a $1 \%$ ), ao longo da área de medida dos fluxos turbulentos ( $1 \mathrm{~km})$ a inundação iniciou-se provavelmente de 3 a 4 semanas antes daquela data. Desta forma, os efeitos da saturação do solo e da inundação devem ter se iniciado no início de Janeiro de 2004.

A altura da inundação foi estimada utilizando um perfil de termopares fixados na torre experimental (Figura 23). A temperatura da água não apresentou um ciclo diurno tão bem definido quanto o da temperatura do ar, além de ser geralmente maior ou igual à temperatura do ar próximo à lâmina d’água durante todo o período de inundação. A altura máxima de inundação foi de 3,5 metros. A inundação na base da torre compreendeu o período do início de fevereiro (dados de perfil de temperatura ainda indisponíveis) até o início de junho, totalizando aproximadamente 5 meses. 


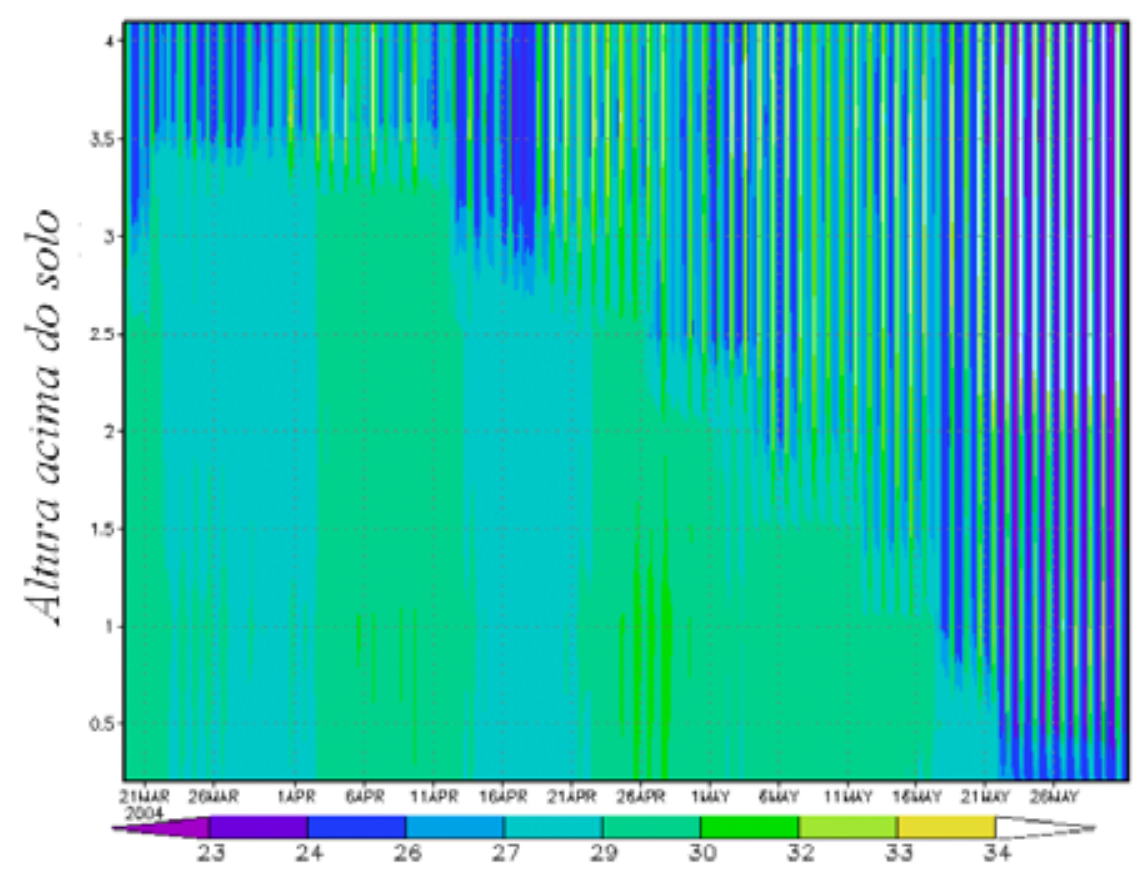

Figura 19- Interpolação da temperatura, em ${ }^{\circ} \mathrm{C}$, medida com um perfil de 09 termopares na base da torre do ecótono Floresta-Cerrado, durante o período de 21 de março a 30 de maio de 2004

\subsubsection{Tolerância à Inundação}

Os mecanismos de tolerância à inundação utilizados pela vegetação levam em conta alguns fatores: o nível de inundação, ou seja, se parcial ou com submersão completa; a altura da lâmina de água sobre o solo, visto que quanto maior a altura, menor será a difusão de $\mathrm{O}_{2}$ no volume de água e conseqüentemente para o solo (Armstrong et al., 1994); e a concentração de $\mathrm{O}_{2}$ dissolvido na água, sendo esta uma função da quantidade de matéria orgânica dissolvida e da temperatura da água (Junk, 1991). De forma geral, os mecanismos de tolerância podem ser resumidos em 3 categorias (Armstrong et al., 1994) :

(i) tolerância envolvendo o transporte interno de gases;

(ii) tolerância envolvendo a adaptação metabólica;

(iii) tolerância envolvendo a ação hormonal;

Os mecanismos de tolerância envolvendo transporte de gases visam permitir, ou facilitar, o transporte de $\mathrm{O}_{2}$ para os tecidos submersos, principalmente para as raízes, e a 
obtenção de $\mathrm{O}_{2}$. A melhora da aeração é obtida com o desenvolvimento de espaços aéreos na estrutura da vegetação, denominados de aerênquimas (Larcher, 2000), que permitem o acúmulo de gases e a difusão ao longo da planta. Para aumentar a obtenção de $\mathrm{O}_{2}$, a vegetação aumenta as superfícies que permitem a troca de gases, no caso das raízes ocorre também a otimização da relação superfície-volume, e estímula o crescimento da parte aérea da vegetação para priorizar a conexão entre planta e atmosfera. Na Amazônia, a formação de aerênquima concentra-se principalmente nas palmáceas, enquanto que a vegetação arbórea apresenta baixa freqüência na formação desta estrutura (Junk, 1991).

A adaptação metabólica à inundação se dá através de (Armstrong et al., 1994):

(i) formação de grandes reservas de energia;

(ii) síntese de macromoléculas específicas;

(iii) proteção contra a pós-anóxia e;

(iv) o controle do metabolismo energético ante à limitação de oxigênio;

$\mathrm{Na}$ ausência de $\mathrm{O}_{2}$ o metabolismo torna-se menos eficiente, levando ao consumo das reservas energéticas da planta e à formação de subprodutos que podem ser tóxicos. Muitas espécies vegetais amazônicas acumulam estas reservas nas raízes e liberam, ou metabolizam, os subprodutos tóxicos, como etanol, no início da fase seca (Junk, 1991).

Outra estratégia metabólica é o controle da produção de certas enzimas. Perante a anóxia, ou hipóxia, a respiração aeróbica não acontece de forma completa, formando dentre os subprodutos tóxicos, o etanol. Uma das adaptações metabólicas possíveis é evitar o incremento da enzima alcool desidrogenase (ADH) durante a ausência de oxigênio. A capacidade de produção de enzimas capazes de substituir o etanol, por outro subproduto durante a anaerobiose, como ácido lático e málico, é fundamental para a sobrevivência à falta de oxigênio e um indicativo da suceptibilidade da espécie à anóxia (Larcher, 2000).

O conhecimento sobre as adaptações hormonais, ainda não totalmente esclarecido, indica os dois hormônios mais importantes: o acido abscísico (ABA) e o etileno (ETH). O ETH é o responsável pela elongação da parte aérea da planta durante o 
regime de inundação e pelo controle na alteração da morfologia das raízes. O ABA é o hormônio responsável pelo controle do funcionamento estomático. Durante a inundação ocorre o fechamento dos estômatos devido à alta concentração de ABA nas folhas. $\mathrm{O}$ ABA também é responsável pela abscisão, sendo esta definida como a perda das folhas, flores e/ou frutos.

\subsubsection{Estado da Atmosfera à superfície}

Desde o início do monitoramento, no final de Outubro de 2003, a precipitação acumulada mostrou-se bastante persistente (Figura 20), evidenciando o período chuvoso. Entre janeiro e março as chuvas mostraram-se mais persistentes. No fim de abril ocorreu uma diminuição na quantidade de chuvas, de forma mais acentuada durante o mês de maio, indicando aí o início da estação seca. A estação seca extendeu-se até meados de setembro, onde algumas chuvas esparsas já foram notadas. A estação seca durou cerca de 4 meses. A precipitação acumulada no período foi cerca de $1690 \mathrm{~mm}$.

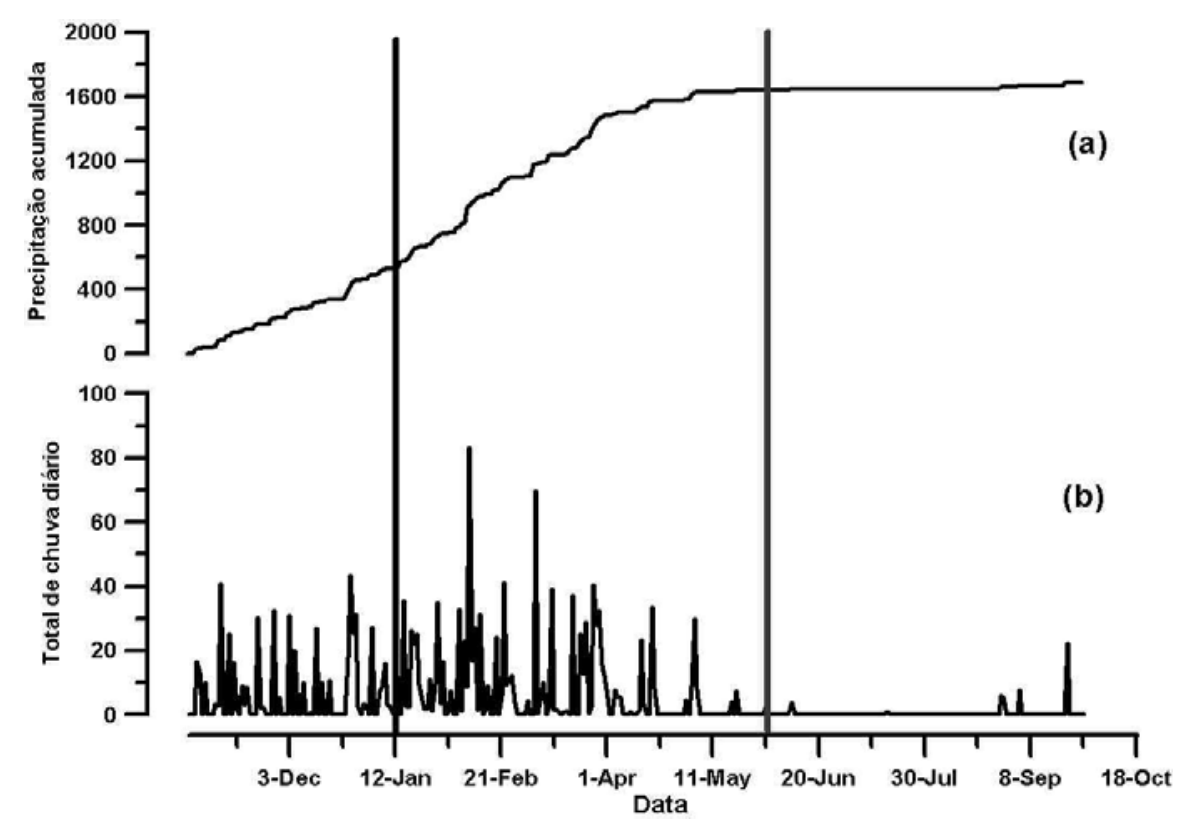

Figura 20 - Precipitação para o período de outubro de 2003 a setembro de 2004, para a área de ecótono. (a) Precipitação acumulada, em mm; (b) Precipitação diária, em mm. As barras verticais indicam o provável início e fim da inundação, respectivamente. 
Ocorreram alguns eventos com queda de árvores próximas da torre (Darius Kurzatkowski - com. pessoal) no fim de dezembro de 2003, em janeiro e em fevereiro de 2004, com data não precisa.

Concorrentemente ao aumento das chuvas há aumento de nebulosidade, o que acarreta a diminuição da oferta da radiação PAR incidente e do saldo de radiação, como será discutido a seguir. Algumas mudanças no estado médio da atmosfera à superfície foram de fato observadas com o início das chuvas mais regulares, em meados de dezembro, e após a inundação.

A temperatura média diária (Figura 21 b) diminuiu com o inicio das chuvas regulares, em janeiro, o que se estabeleceu juntamente com o aumento da nebulosidade. À partir de março, até maio, ocorre um aumento suave e gradual da temperatura. Com o fim do período chuvoso há um sistemático aumento de temperatura, que se extende por toda a inundação e acentua-se após o término desta. Na estação seca, à partir de maio, ocorre um evento de queda acentuada de temperatura, provavelmente associado à uma frente fria, no fim de julho.

A umidade relativa do ar média diária (Figura 21 c) manteve-se bastante alta durante a fase chuvosa. Com o fim do período chuvoso e com o aumento de temperatura, inicia-se uma diminuição da umidade relativa, mesmo havendo ainda a inundação. A diminuição da umidade relativa do ar acentua-se após o término da inundação, variando entre 50 e 60 \%. Após o fim da inundação a umidade relativa mostrou-se abaixo de 30\% em alguns casos. 


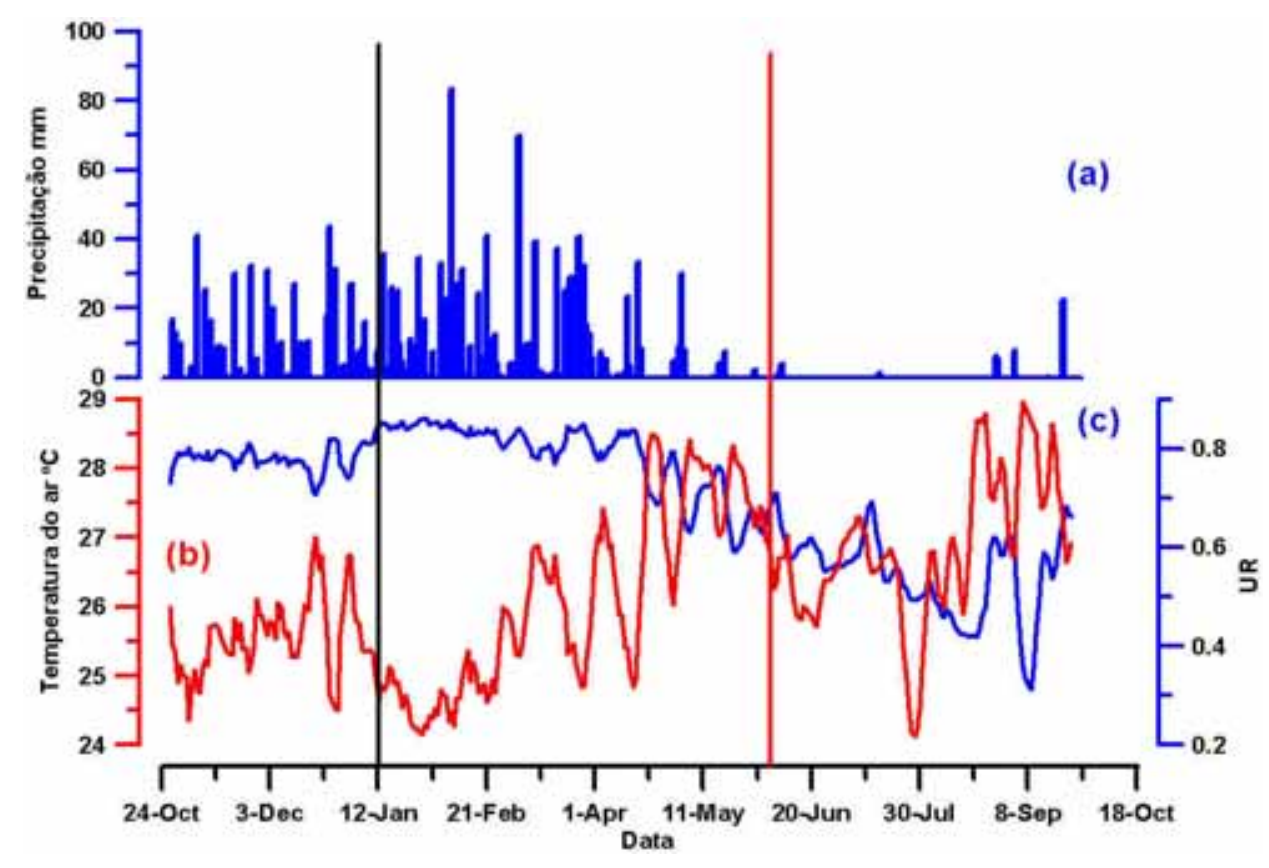

Figura 21- Período de outubro de 2003 a setembro de 2004, na área de ecótono FlorestaCerrado. (a) Precipitação diária, em mm; Média móvel diária de (b) temperatura do ar, em ${ }^{\circ} \mathrm{C}$, (linha vermelha); (c) umidade do ar (linha azul). A barra vertical preta denota o provável inicio da inundação. A barra vermelha aponta para o provável fim da inundação

As medidas de pressão de vapor d’água (Figura 22b) apresentaram uma leve tendência de aumento com a progressão da estação chuvosa, que não volta a diminuir durante quase toda a fase de inundação. Próximo ao fim da inundação inicia-se uma tendência de diminuição da pressão de vapor.

Durante o período observado os extremos da velocidade do vento (Figura 22b) acompanharam principalmente a ocorrência de chuvas. Com o fim do período chuvoso as medidas predominaram abaixo de $8 \mathrm{~m} \mathrm{~s}^{-1}$. No início de agosto a entrada de uma frente fria provocou uma considerável diminuição de temperatura e aumento da velocidade do vento. 


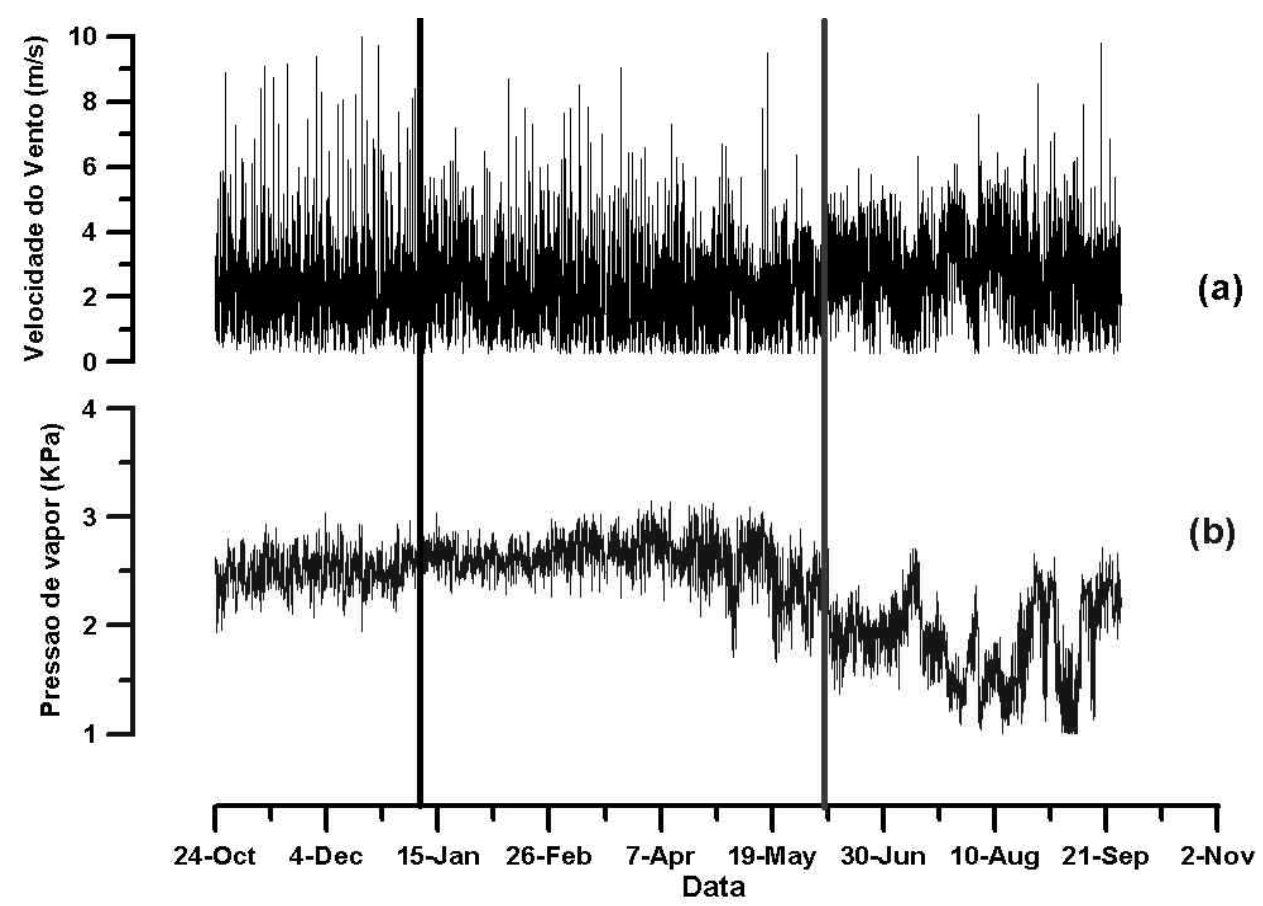

Figura 22 - Médias de 15 minutos para o período de outubro de 2003 a setembro de 2004, no ecótono Floresta-Cerrado de : (a) Velocidade do vento, em m/s ; (b) pressão de vapor d’água, em KPa. As barras verticais indicam o provável início e fim da inundação, respectivamente.

\subsubsection{Radiação}

As medidas de irradiância incidente (solar global e PAR) foram controladas por dois mecanismos distintos (Figura 23). O primeiro foi a nebulosidade, que através da alternância entre dias de céu limpo e parcialmente nublado, provoca a redução da radiação durante o período chuvoso, e sugere uma série temporal bastante estacionária no período seco. O segundo mecanismo é obviamente o fator astronômico, que em $10^{\circ} \mathrm{S}$ de latitude reduz a irradiância incidente a um mínimo no solstício de inverno (21 junho), ou seja, coincidente com a fase seca, e um máximo no solstício de verão (21 dezembro).

O saldo de radiação mostrou-se também com um padrão sazonal controlado pela variabilidade da irradiância solar. Os valores médios diários oscilaram entre 100 a 200 $\mathrm{W} \mathrm{m} \mathrm{m}^{-2}$ durante o período de estudo. 


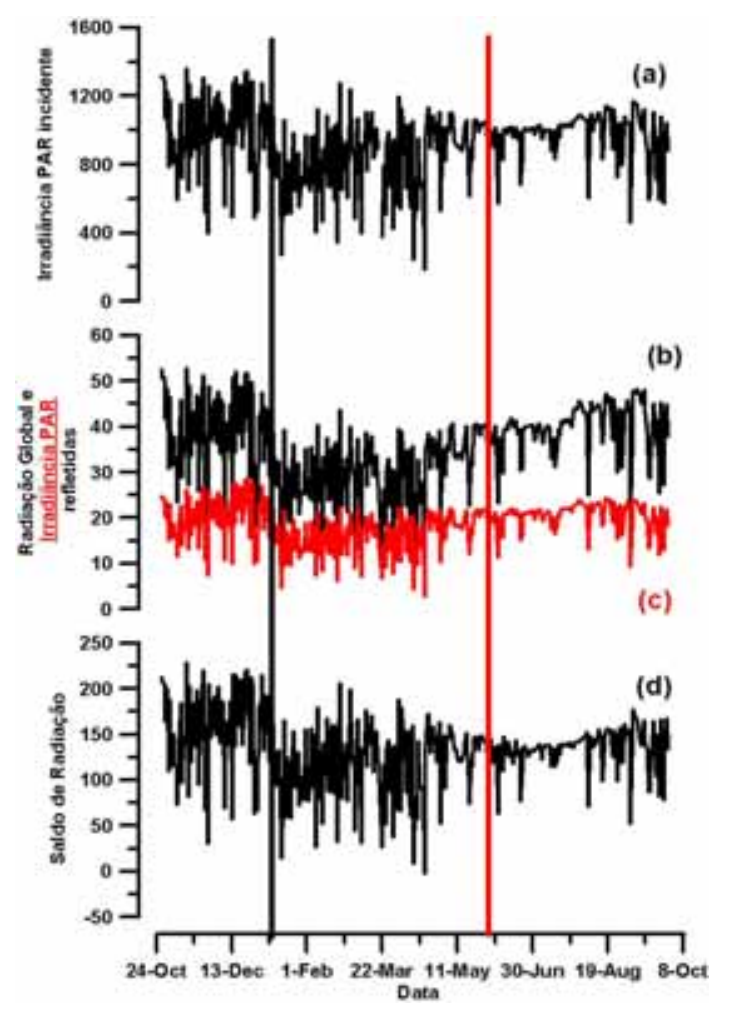

Figura 23 - Média diária de (a) Irradiância PAR incidente, em $\mu \mathrm{mol} \mathrm{m} \mathrm{m}^{-2} \mathrm{~s}^{-1}$; (b) Irradiância solar global refletida (linha preta), em $\mathrm{Wm}^{-2}$; (c) Irradiância PAR refletida (linha vermelha) em $\mu \mathrm{mol} \mathrm{m} \mathrm{s}^{-2} \mathrm{~s}^{-1}$; (d) Saldo de radiação, em $\mathrm{Wm}^{-2}$, no período de outubro de 2003 a setembro de 2004, para o sítio do ecótono Floresta-Cerrado. A barra vertical preta denota o provável inicio da inundação. A barra vermelha aponta para o provável fim da inundação

Com a inundação, ocorre a cobertura do solo pela água na superfície abaixo do dossel. Desta forma a água (ou o solo úmido) absorveria mais radiação que o solo seco, causando assim uma diminuição na radiação total refletida e uma provável diminuição dos valores de albedo total.

Neste caso, o Albedo-PAR indica a fração de PAR refletida pelo sistema soloágua-vegetação e pode ser correlacionado com a taxa fotossintética e com a biomassa verde do ecossistema. Á princípio, quanto maior a biomassa verde, ou a taxa fotossintética, menor é o valor de Albedo-PAR, que pode ser um indicador do estado funcional do ecossistema. 
Na variação do Albedo-PAR médio diário com o tempo (Figura 24), observa-se o aumento entre outubro e o fim de dezembro (de 1,9 a 2,1\%), seguido de uma inversão da tendência (redução) até meados de março (de 2,1 a 1,8\%). No início de abril reverte novamente a tendência (aumento) até o início de junho, atingindo novamente 2,1\%, quando então mantêm-se aproximadamente estacionário. A variabilidade absoluta foi portanto pequena, de $\sim 0,3 \%$, e de $\sim 17 \%$ em termos relativos. Apesar da baixa amplitude anual, as tendências mostradas na série temporal foram muito bem definidas, o que sugere que as mudanças na capacidade fotossintética do ecossistema são sutis, mas bem delimitadas e com um sinal algébrico inequívoco (de tendência).

A variabilidade sazonal indica, de forma geral, poderia haver uma flutuação bimodal, com um máximo em dezembro, na transição da estação seca-chuvosa, e outro no final do período de inundação, em junho. Seriam desta maneira quatro fases a explicar.

Entre outubro e fevereiro, observam-se dois padrões diferentes. Inicialmente, o crescimento do Albedo-PAR, de outubro a dezembro. Isto não seria esperado no início da fase chuvosa, em um cerrado seco, uma vez que a atividade fotossintética estaria aumentando. Sugere-se assim que este padrão decorra :

(i) pela floração de algumas árvores, aumentando a refletância PAR;

(ii) pela troca das folhas no inicio da estação chuvosa, como uma possível estratégia ecológica.

Como o período de frutificação de muitas espécies amazônicas coincide com o período de inundação (Junk, 1991), a hipótese de floração tem um reforço.

A diminuição do Albedo-PAR entre dezembro e março, seria decorrente da rebrota das folhas da vegetação. Esta rebrota teria sido disparada, por mecanismos internos da planta, antes da inundação.

No meio do período de inundação, no início de março, reconfigura-se a tendência de crescimento do Albedo-PAR, concorrente com o avanço do alagamento. Explica-se que este tenha sido um mecanismo induzido pelo estresse da inundação. O início deste processo de senescência, nesta forma de raciocínio, não foi respondido imediatamente à 
inundação. A aeração das raízes é um dos maiores problemas gerados pela inundação, e a folha é a principal via de troca gasosa da vegetação. $\mathrm{O}$ avanço do tempo de residência da vegetação sob o alagamento vai reduzindo a aeração dos tecidos, subterrâneos ou não. Conseqüentemente a respiração aeróbica vai perdendo domínio sobre o metabolismo anaeróbico, aumentando concomitantemente a produção de subprodutos tóxicos como o etanol.. O estresse promovido por estes metabólitos secundários é somado a produção de superóxidos, após a reintrodução do oxigênio no fim da inundação, configurando assim o estresse pós-anóxia. Adicionalmente, após um longo período de alagamento, espera-se o aumento da concentração de ABA nas folhas, induzindo a senescência em muitas espécies (Armstrong et al., 1994).

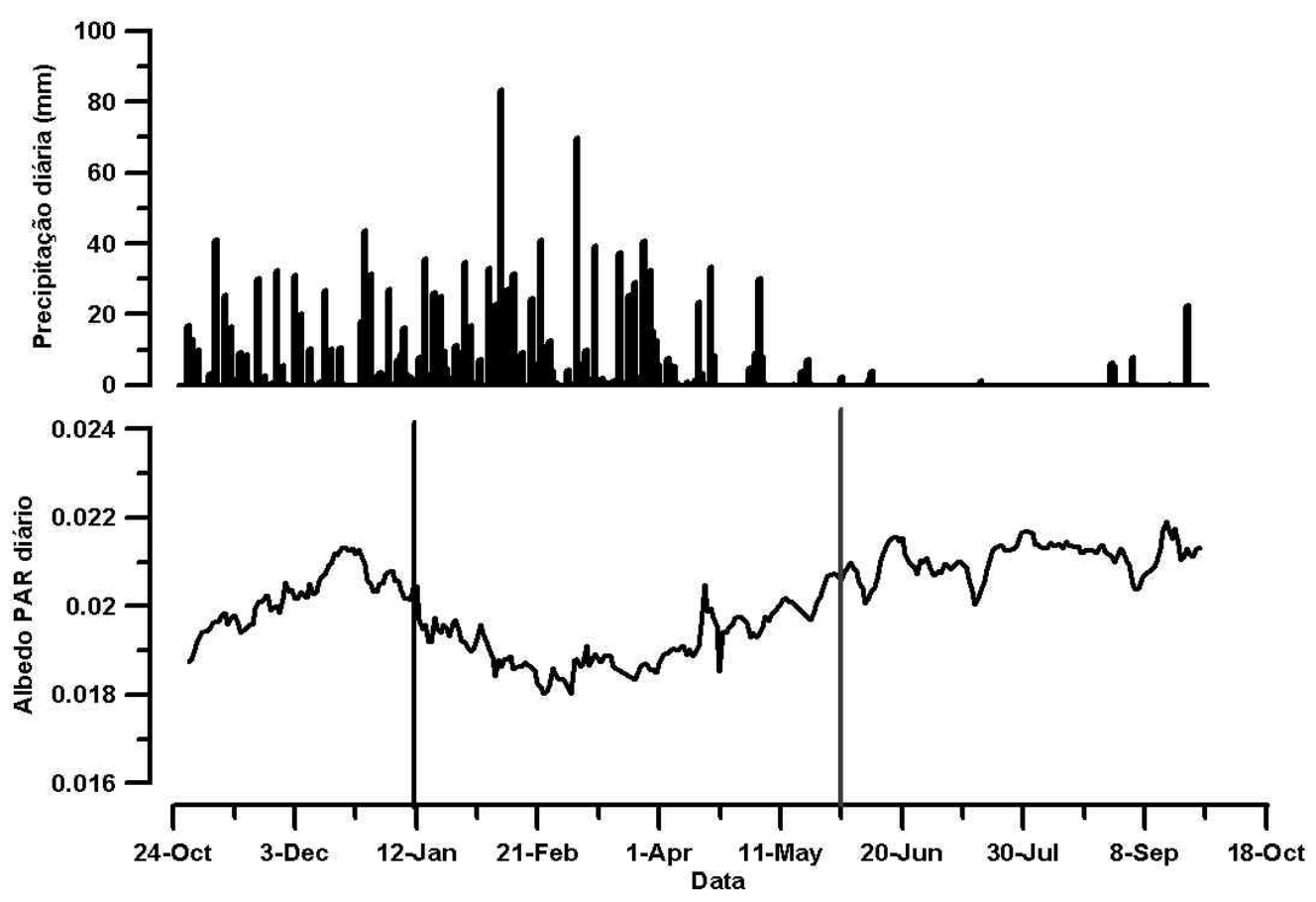

Figura 24 - Albedo-PAR médio diário para o período de outubro de 2003 a setembro de 2004. Para o sítio do ecótono Floresta-Cerrado. As barras verticais indicam o provável início e fim da inundação, respectivamente.

Mesmo após o fim da inundação, o efeito de estresse sobre o ecossistema ainda não terminou. A pós-anóxia pode gerar um estresse de mesma ordem, ou maior, que a anóxia e, conseqüentemente, induzir a perda de folhas e mortalidade de indivíduos 
(Armstrong et al., 1994). Seguindo este raciocínio, a tendência de crescimento do Albedo-PAR avançou até aproximadamente um mês após o término da inundação na base da torre.

Em junho de 2004, e nos próximos quatro meses, o Albedo-PAR ficou estacionário em $\sim 2,2 \%$. Nesta época a vegetação proveria de um período de estresse devido à anóxia e pós-anóxia, e tem, como ponto de partida o início de julho, uma quantidade alta e suficiente de água e radiação para manter uma alta capacidade fotossintética, sendo estimulada à recuperá-la. São condições iniciais ambientais favoráveis à recuperação, quando a vegetação tenderia a alocar energia para o crescimento. Este mecanismo corrobora a noção de fase de crescimento do tronco das árvores nas áreas de várzea, principalmente após a fase inundada (Dezzeo et al., 2003). A observação de que o Albedo-PAR não mostrou uma tendência de crescimento durante a fase seca, onde há uma redução nítida e gradual da umidade do solo, sugere que não houve aparentemente redução da capacidade fotossintética. Em outras palavras, isto também sugere que o estresse por déficit hídrico não foi um forte limitante no processo de crescimento, pelo menos nos quatro meses de observação no final do período de estudo. Este argumento será enfocado novamente a seguir, confirmado pelo padrão de variabilidade dos fluxos de $\mathrm{CO}_{2}$ medidos na torre.

\subsubsection{Processos no solo}

O efeito da inundação dos solos é tanto químico, quanto mecânico. A mobilidade dos elementos segue a sequencia: $\mathrm{Ca}>\mathrm{Na}>\mathrm{Mg}>\mathrm{K}>>\mathrm{Si}>>\mathrm{Fe}>>\mathrm{Al}$, e assim, devido à lixiviação dos outros elementos, solos bem drenados e intemperizados tendem a acumular $\mathrm{Al}$ e Fe. Este processo é denominado acumulação passiva de ferro.

Porém, em solos inundados também pode ocorrer a acumulação ativa de Ferro. O oxigênio é o aceptor de elétrons principal do processo respiratório. Quando o solo está saturado, não existe oxigênio disponível, e então o $\mathrm{Fe}^{3+}$ é utilizado como aceptor de elétrons, resultando em $\mathrm{Fe}^{2+}$, que, uma vez dissolvido, pode ser transportado para camadas mais inferiores do solo. Quando o solo não está saturado, na presença do 
oxigênio, o $\mathrm{Fe}^{2+}$ é oxidado para $\mathrm{Fe}^{3+}$ e precipitado nas camadas inferiores do solo como mineral férrico. Inicialmente o produto desta deposição não é duro, mas com o tempo vai endurecendo irreversivelmente, mesmo perante umidade, formando a laterita ou plintita. Este processo do efeito da inundação nos solos, descrito por Motta et al. (2002), sugere uma forma de entendimento da dinâmica de transição Floresta-Cerrado.

A análise comparativa de solos entre Floresta e diversas fisionomias de Cerrado ainda não é conclusiva. A qualidade e a disponibilidade de nutrientes no solo mostraram que existe uma diferença na quantidade de nutrientes, na Gleba Pé de Gigante, entre o solo de Floresta semidecídua e do Cerrado, enquanto que no solo sob as fisionomias de Cerrado não existem diferenças significativas (Ruggiero et al., 2002). Comparando Cerrado s.s. e Cerradão, Haridassan (1992) reportou que não existe diferença significativa de nutrientes no solo entre as fisionomias. Enquanto que (Ratter, 1992) reportou que no limite entre Floresta-Cerrado não existe diferença em solos distróficos, porém existe diferença em solos mesotróficos.

A dinâmica da água no solo do ecótono Floresta-Cerrado pode ser o mecanismo chave para a compreensão da dinâmica nesta interface.

\subsubsection{Umidade do Solo}

É esperado que a umidade do solo e a inundação desempenhem um papel fundamental no controle estomático e na senescência e, consequentemente, nos fluxos de energia e de $\mathrm{CO}_{2}$ do ecossistema. Os refletômetros no domínio da freqüência foram instalados em diferentes profundidades (veja Tabela 1), formando um perfil de amostragem da umidade do solo da superfície até 2 metros. A estimativa da umidade volumétrica foi realizada sem calibração, utilizando-se a curva do fabricante do equipamento para solo arenoso (Campbell 1996). No entanto, isto permitirá que as análises sejam realizadas com propriedade, no ponto de vista da variação da umidade no tempo.

O padrão de umidade do solo (Figura 25), nos dias que antecederam a inundação, mostra que o umedecimento do solo até a saturação ocorreu do início de novembro até o 
início de dezembro de 2003. Em meados de janeiro, o solo estava em condições próximas da saturação, indicando que do início das chuvas mais regulares até a saturação do solo transcorreu aproximadamente 45 dias. Este fato tem, potencialmente, grande efeito para rebrota da vegetação, para o estrato herbáceo e para o banco de plântulas.

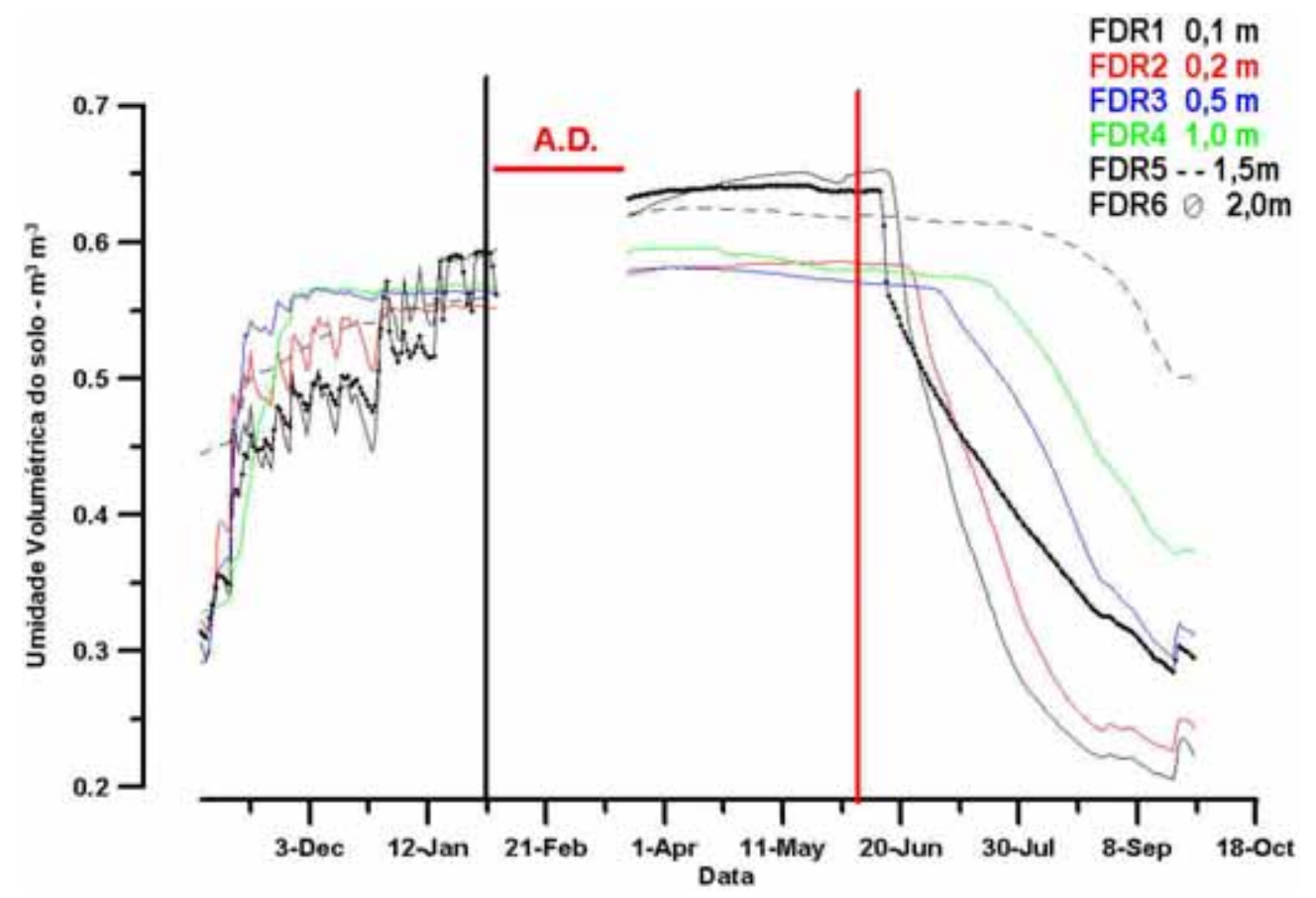

Figura 25 - Médias diárias da umidade volumétrica em 6 níveis para o período de outubro de 2003 a setembro de 2004. Para o sítio do ecótono FlorestaCerrado. A barra vertical preta denota o provável inicio da inundação. A barra vermelha aponta para o provável fim da inundação. A barra horizontal vermelha indica ausência de dados (A.D.)

Durante a inundação a umidade do solo manteve-se constante até o início de junho, quando, à partir de então, principalmente nos níveis mais superfíciais, iniciou uma acentuada depleção (Figura 25).

Observa-se resumidamente três períodos distintos na evolução temporal da umidade do solo (Figura 25). O primeiro é o período de pré-inundação (na base da torre, ou seja, até o início de fevereiro), onde as camadas superficiais tem menor umidade que as camadas mais profundas. Particularmente no primeiro mês, houve um acentuado 
umedecimento, que poderia ter resultado da própria infiltração da chuva ou da elevação do nível do lençol freático. Como aparecem os pulsos de infiltração claramente nesta fase, acredita que a infiltração tenha sido o mecanismo predominante de umedecimento do perfil. O período seguinte é a inundação propriamente dita, onde todo o solo está saturado. Se o solo fosse perfeitamente homogêneo, quanto à porosidade, as medidas de umidade seriam muito próximas. Portanto, a diferença dos patamares de umidade neste período devem se reduzir com um procedimento de calibração dos sensores, para cada profundidade específica.

O terceiro período ocorre após a inundação. Analisando as profundidades separadamente, as camadas superficiais e as intermediárias apresentaram uma maior taxa de diminuição de umidade com o tempo. As camadas mais profundas (1 a 2 m) foram as que secaram mais lentamente. Este padrão sugere que as medidas refletiram razoavelmente o fenômeno da redução da inundação, que irá secar as camadas de solo de cima para baixo. A drenagem, em um solo saturado e arenoso como o da área experimental, deveria mostrar-se o mecanismo predominante no processo de secamento.

Uma estimativa simplificada poderia ser feita, por exemplo, na camada média de 0 a $1 \mathrm{~m}$, mostrada pela variação de aproximadamente $0,6 \mathrm{~m}^{3} \mathrm{~m}^{-3}$ (no final da inundação) para $0,3 \mathrm{~m}^{3} \mathrm{~m}^{-3}$ (dia 30/09/2004), durante aproximadamente 90 dias. Isto corresponderia a aproximadamente $300 \mathrm{~mm}$ no primeiro metro, ou seja, 3,3 mm/dia como taxa média de depleção da umidade do solo. Na profundidade de 1 a 2 m, a variação estimada poderia ser de $0,6 \mathrm{~m}^{3} \mathrm{~m}^{-3}$ para $0,5 \mathrm{~m}^{3} \mathrm{~m}^{-3}$, portanto aproximadamente $1,1 \mathrm{~mm} /$ dia como uma taxa média naquele período. A soma na profundidade de 0 a $2 \mathrm{~m}$, igual a $4,4 \mathrm{~mm} /$ dia, mostrase bastante comparável com valores de evapotranspiração em áreas florestais, indicando que o secamento observado pode ser associado em grande parte devido à atividade do sistema radicular, e consequentemente do metabolismo da vegetação, e não totalmente creditado aos fenômenos de drenagem vertical. 


\subsubsection{Fluxos de superfície}

A concentração de $\mathrm{CO}_{2}$ atmosférico medida no topo da torre (Figura 26) apresenta uma tendência de diminuição, desde outubro de 2003, até o início de março de 2004, podendo em um primeiro momento, significar tendência de remoção de $\mathrm{CO}_{2}$ pelo na superfície em escala regional. Após o auge da inundação, a concentração de $\mathrm{CO}_{2}$ apresenta uma tendência de aumento. Isto sugere que poderia haver um novo modo de funcionamento, onde a superfície estaria perdendo $\mathrm{CO}_{2}$ para a atmosfera, até mesmo decorrente da inundação. Em grande parte, este tipo de relação causa-efeito será confirmada pelos fluxos de $\mathrm{CO}_{2}$ observados na torre micrometeorológica. De maneira geral, a variabilidade de $\mathrm{CO}_{2}$ média depende também dos transportes de outras regiões, além da própria redistribuição vertical que ocorre no transporte de nuvens cúmulos e nos movimentos de subsidência. Portanto parte da explicação para a variabilidade observada será discutida neste trabalho.

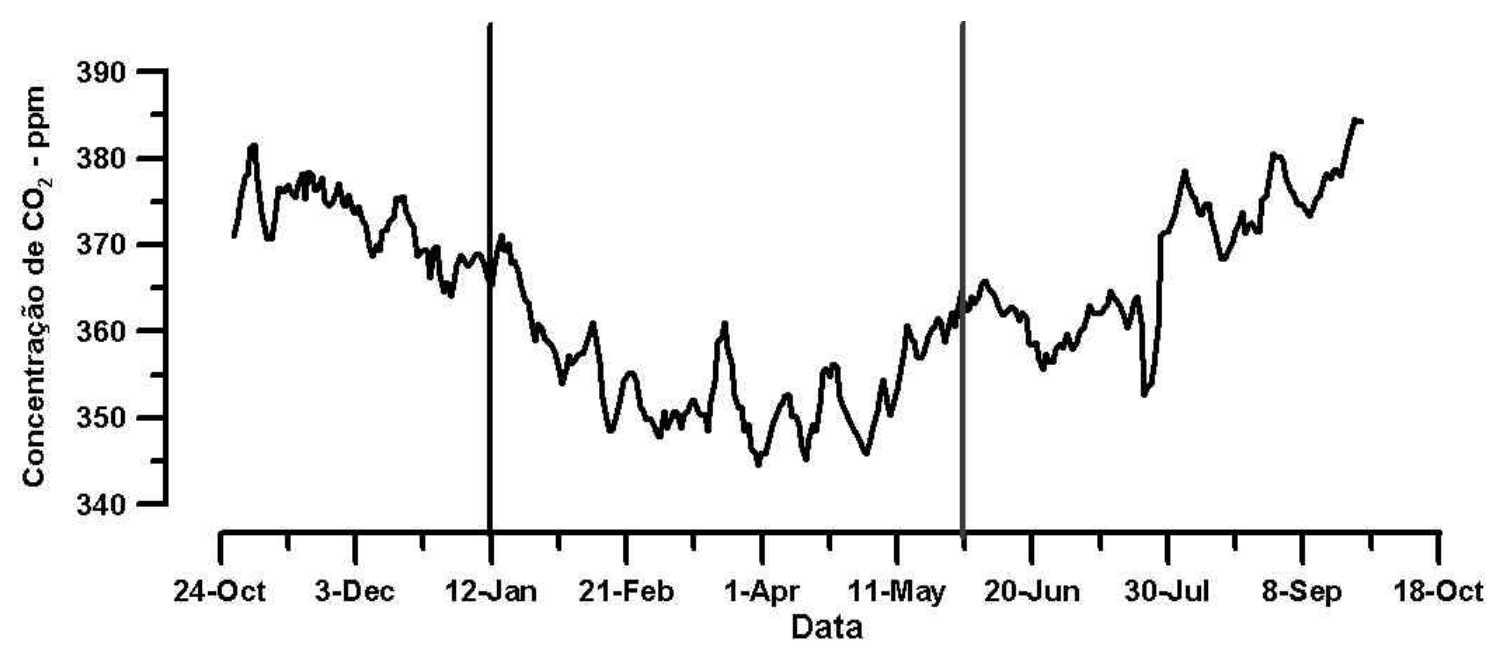

Figura 26 - Média diáriade concentração de $\mathrm{CO}_{2}$, em ppm, para o período de outubro de 2003 a setembro de 2004, no sítio do ecótono Floresta-Cerrado. As barras verticais indicam o provável início e fim da inundação, respectivamente.

Os fluxos turbulentos de calor sensível e calor latente (Figs. 27 a, b) são função da disponibilidade de água no sistema e da energia disponível. Ambos os fluxos apresentam uma diminuição após a intensificação do período chuvoso, em janeiro, 
decorrente do aumento da nebulosidade e redução do saldo de radiação. De forma geral, o fluxo de calor latente médio diário atingiu faixas de valor máximo de aproximadamente $160 \mathrm{Wm}^{-2}$, enquanto o fluxo de calor sensível atingiu nesta faixa máxima valores de aproximadamente $70 \mathrm{Wm}^{-2}$. Desta forma, como padrão predominante observado em todo o período de estudo, houve um claro predomínio do calor latente na partição de energia, o que definiu uma variabilidade da razão de Bowen média diária entre 0,1 e 0,4 (Figura 27a).

O Fluxo de calor sensível (Hs) (Figura 27 c) apresenta uma diminuição após a inundação, tanto em seus valores absolutos, quanto em sua amplitude, esta última decorre parcialmente do aumento da capacidade térmica do sistema, nesta ocasião com água.

Poderia-se esperar dois diferentes padrões para a tendência do sinal da evapotranspiração (LE) com o evento da inundação. O primeiro seria um aumento, devido ao aumento da área alagada, e conseqüentemente o aumento da disponibilidade de água disponível. O segundo seria uma diminuição, visto que um dos efeitos da inundação na vegetação seria o fechamento estomático e a conseqüente diminuição da transpiração foliar. O padrão descrito na Figura 27 demonstra que o efeito do alagamento é dominante, sobrepujando o efeito da diminuição da transpiração, se este tiver ocorrido de alguma forma. 


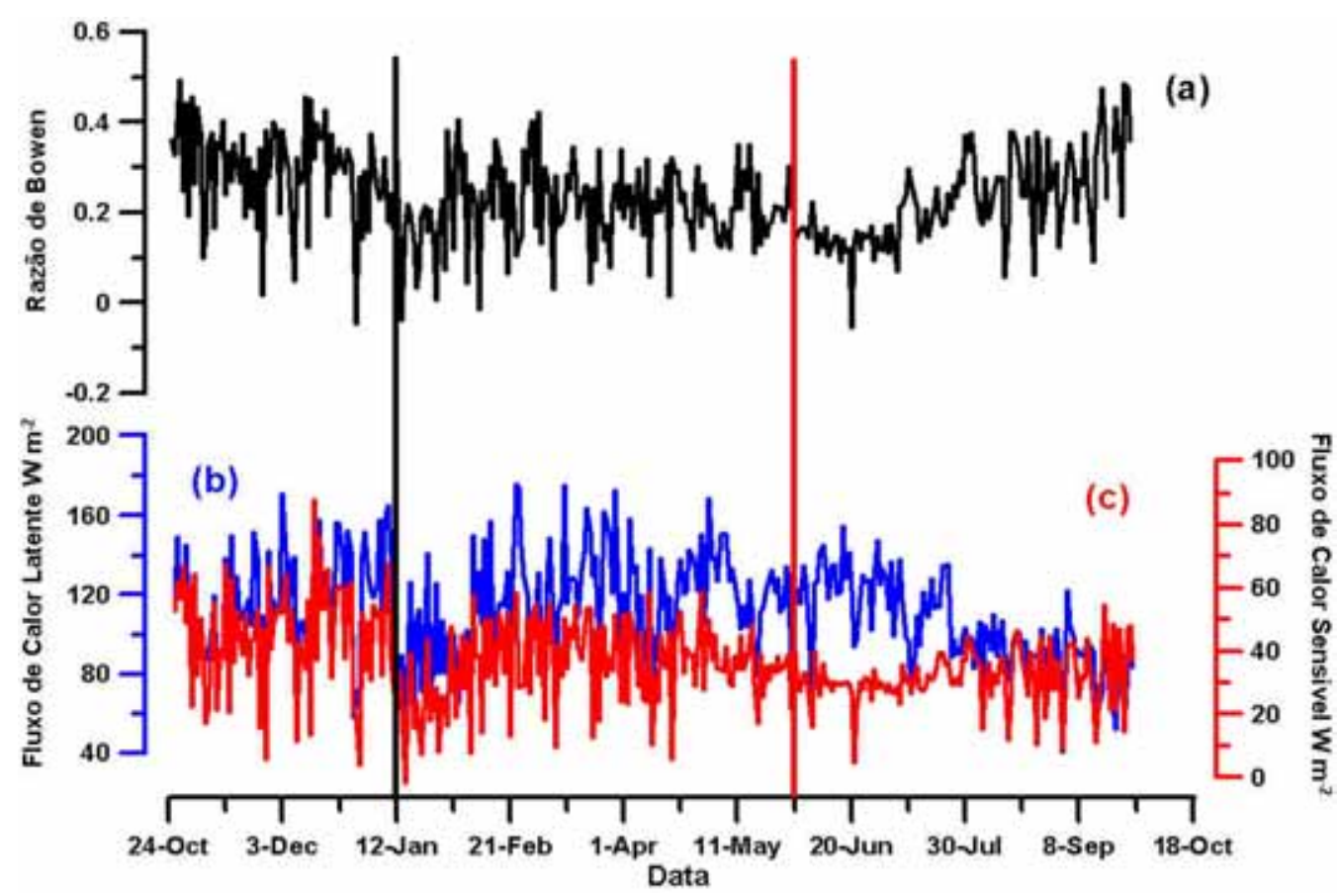

Figura 27- Média diária de (a) razão de Bowen; (b) Fluxo de calor latente, em W m²; (c) Fluxo de calor sensível, em $\mathrm{W} \mathrm{m}^{-2}$, para o período de outubro de 2003 a setembro de 2004, no sítio do ecótono Floresta-Cerrado. A barra vertical preta indica o provável inicio da inundação. A barra vermelha indica para o provável fim da inundação

Ocorre uma diminuição da razão de Bowen média diária (Figura 27 a) como efeito do alagamento, de aproximadamente 0,4 para 0,2, após a intensificação das chuvas e o início da inundação. A grande quantidade de água livre na superfície faz com que a energia disponível seja utilizada no sistema prioritariamente para a mudança de estado físico da água, em detrimento do aumento de temperatura. Logo após a data provável de fim do alagamento, a razão de Bowen ainda permanece reduzida. Entretanto, acredita-se que esta redução ainda seja um efeito do alagamento, que manteve o solo saturado nas áreas de menor cota ao longo da área de observação da torre. Em outras palavras, a data de fim de alagamento é apenas uma referência na base da torre, os seus efeitos ainda repercutem-se em áreas vizinhas, de menor cota, onde a saturação é mais prolongada. 
Finalmente, com o desenvolvimento do período seco, a razão de Bowen volta a recuperar os valores mais altos observados nos meses do final de 2003, priorizando o fluxo de calor sensível.

\subsubsection{Fluxos turbulentos de $\mathrm{CO}_{2}$}

É esperado que a sazonalidade que controlou as variações encontradas nos fluxos de energia também influencie, em maior ou menor grau, o padrão dos fluxos turbulentos de $\mathrm{CO}_{2}$.

A variação temporal do fluxo total de $\mathrm{CO}_{2}$ médio diário (Figura 28 a) mostrou uma tendência de diminuição após a inundação (o que significa um aumento da assimilação de $\mathrm{CO}_{2}$ na superfície), que reverteu-se um pouco mais tarde, no início de março, no auge da inundação (Figura 28 a), mostrando que o ecossistema começou a reduzir a capacidade fotossintética com um certo atraso, o que poderia ser argumentado de forma exatamente similar ao padrão de variação do Albedo-PAR. Após o período da inundação, os fluxos de $\mathrm{CO}_{2}$ novamente começaram a indicar um aumento da assimilação (Figura 28), o que corrobora o controle do alagamento de forma nítida nas trocas de carbono.

Ao separar-se o fluxo total de $\mathrm{CO}_{2}$ médio diário em suas componentes de fluxo diurno (Figura 28 c), um dado proxi da produtividade, e fluxo noturno, um proxi para a respiração do sistema (Figura 28 b), pode-se analisar de forma mais clara o efeito da inundação.

O estado do sistema antes da inundação indica uma alta atividade, com um fluxo total médio diário de $\mathrm{CO}_{2}$ de cerca de $-4 \mu \mathrm{mol} \mathrm{CO}_{2} \mathrm{~m}^{-2} \mathrm{~s}^{-1}$. No mesmo período, o sistema apresentou um ganho diurno de cerca de $-8 \mu \mathrm{mol} \mathrm{CO}_{2} \mathrm{~m}^{-2} \mathrm{~s}^{-1}$. Os fluxos noturnos estiveram, nesta período, em $\sim+4 \mu \mathrm{mol} \mathrm{CO}_{2} \mathrm{~m}^{-2} \mathrm{~s}^{-1}$, mostrando uma substancial taxa de respiração do sistema.

Após a inundação, acredita-se, ocorreram mudanças nas características estruturais e funcionais do sistema, para uma condição diferente e, conseqüentemente, um regime variante de funcionamento. 
O fluxo diurno médio de $\mathrm{CO}_{2}$ é um dado proxi da produtividade. Como existe na fotossíntese uma constante demanda por $\mathrm{O}_{2}$, a anóxia causada pela inundação teria um alto potencial de estresse imediato. Porém isto não foi observado exatamente desta maneira. No período de pré-inundação notou-se uma assimilação diurna média de -8 $\mu \mathrm{mol} \mathrm{CO}_{2} \mathrm{~m}^{-2} \mathrm{~s}^{-1}$ (Figura $28 \mathrm{c}$ ). Porém, imediatamente após a inundação, a assimilação diária aumentou, atingindo $\sim-12 \mu \mathrm{mol} \mathrm{m}^{-2} \mathrm{~s}^{-1}$. A tendência de diminuição da assimilação do ecossistema, ou produtividade diária, somente aparece à partir do final de fevereiro. Nesta ocasião a produtividade diminui, embora a radiação PAR passe por um período de crescimento, o que indica que não foi a redução de energia (Figura 28 d) a causa da perda de produtividade. Portanto foi numa escala de aproximadamente 60 dias que os efeitos de estresse na produtividade apareceram nas medidas de fluxos atmosféricos de $\mathrm{CO}_{2}$. Isto sugere que há uma substancial adaptação, e refuta a hipótese inicial de que haveria uma rápida resposta ao estresse provocado pela inundação.

Este sinal de reversão da tendência de assimilação de $\mathrm{CO}_{2}$ no fluxo médio diurno (Figura 28c), no meio do período de inundação, também mostrou-se nítida no fluxo total de $\mathrm{CO}_{2}$ (Figura 28a). Neste caso, o sistema foi levado à uma condição próxima ao ponto de compensação entre produtividade primária líquida e respiração do ecossistema, ou seja, fluxo total de $\mathrm{CO}_{2}$ igual a aproximadamente zero. Este ponto ocorreu, coincidentemente, no final do período de inundação, no início de junho de 2004 (Figura 28a).

O fluxo noturno médio diário de $\mathrm{CO}_{2}$, em todo o período, variou de $\sim+4 \mu$ mol $\mathrm{CO}_{2} \mathrm{~m}^{-2} \mathrm{~s}^{-1}$, em novembro de 2003 (pré-inundação), reduzindo-se gradualmente, até $+0,75 \mu \mathrm{mol} \mathrm{CO} \mathrm{Cm}^{-2} \mathrm{~s}^{-1}$ em meados de abril de 2004 (auge da inundação), portanto uma redução de $\sim 80 \%$ na respiração do ecossistema. Esta redução teria ocorrido principalmente por duas razões. A primeira é devido ao próprio ambiente da inundação como fonte de emissão, em sustituição ao solo com serapilheira como a fonte propriamente dita, antes da inundação. Na inundação as perdas noturnas ocorrem por evasão de $\mathrm{CO}_{2}$ à superfície, um processo controlado pela concentração de $\mathrm{CO}_{2}$ na água $\left(\mathrm{pCO}_{2}\right)$ e pela intensidade da difusão do $\mathrm{CO}_{2}$ na camada laminar entre a superfície da água e o ar. Isto sugere que no processo de evasão de $\mathrm{CO}_{2}$ perdeu-se menos do que no 
processo durante a fase seca, que poderia ser simplesmente chamado de respiração do solo.

Em uma segunda análise, pode-se argumentar também que a redução nos fluxos noturnos ocorrem porquê houve uma redução da capacidade fotossintética, o que reduz a respiração da planta. Este mecanismo, que ocorre de dia e à noite, contribuiria assim também com uma redução das perdas noturnas, comparando-se com o período antes da inundação.

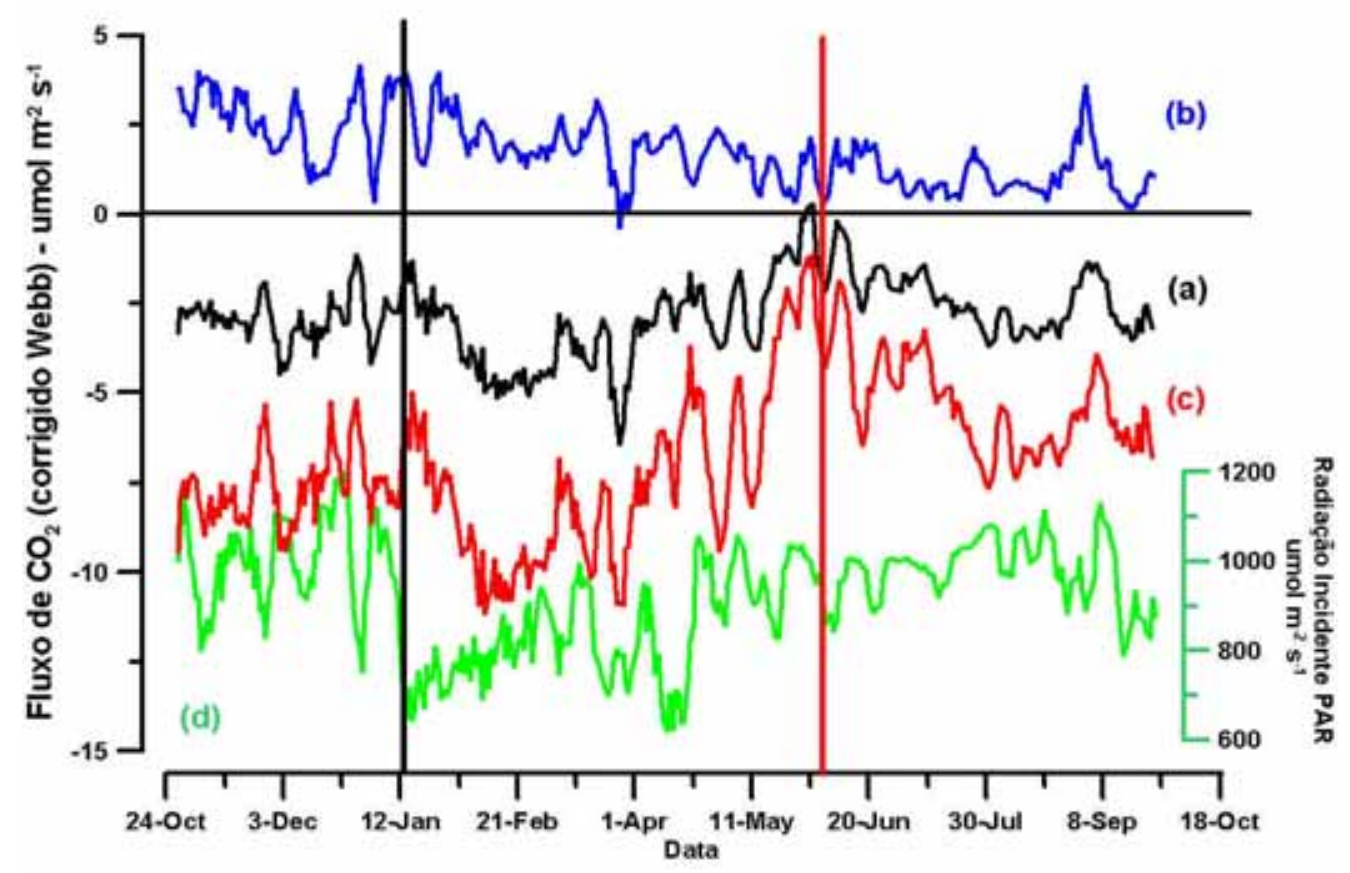

Figura 28 - Média móvel diária de (a) Fluxo de $\mathrm{CO}_{2}$ total; (b) Fluxo de $\mathrm{CO}_{2}$ noturno; (c) Fluxo de $\mathrm{CO}_{2}$ diurno; (d) Irradiância PAR incidente, em $\mu \mathrm{mol} \mathrm{CO}_{2} \mathrm{~m}^{-2} \mathrm{~s}^{-1}$, para o período de outubro de 2003 a setembro de 2004 para o sítio do ecótono Floresta-Cerrado. A barra vertical preta indica o provável inicio da inundação. A barra vermelha indica para o provável fim da inundação

Com o fim do alagamento, do aumento da temperatura e da oferta de radiação, a produtividade voltou a crescer, assim como o fluxo total de $\mathrm{CO}_{2}$ retornou para faixas de maior assimilação, ao redor de $-4 \mu \mathrm{mol} \mathrm{CO} \mathrm{CO}^{-2} \mathrm{~s}^{-1}$ (Figura 28a,c). Os fluxos noturnos de $\mathrm{CO}_{2}$ também estabilizaram a tendência de decréscimo, após o alagamento (Figura 28b). Poderia-se esperar um sinal mais evidente de aumento dos fluxos noturnos com o 
decorrer do período seco. Esse aumento ocorreu de fato, mas foi observado nos dados corrigidos com o armazenamento do perfil (NEE ou troca líquida do ecossistema) (não mostrados).

A observação dos fluxos de $\mathrm{CO}_{2}$ em áreas de campos alagáveis no Pantanal Brasileiro (Alvalá et al., 2004) mostraram que, logo após a inundação ocorreu um aumento da emissão de $\mathrm{CO}_{2}$ noturno, e uma redução da assimilação diurna. Durante a maior parte do período de inundação ocorreu uma grande emissão de $\mathrm{CO}_{2}$ pelo sistema . $\mathrm{O}$ período de maior assimilação de $\mathrm{CO}_{2}$ ocorreu na transição entre a inundação e o período seco, e após isto, durante o período seco, o sistema se aproximou da neutralidade. A informação de Alvalá et al. (2004) no Pantanal concorda em parte com o observado na Ilha do Bananal. Possivelmente a transição do período inundado para o seco, no Pantanal, seja a fase em que a vegetação incorpora carbono, passando logo a seguir, por uma fase de estresse em que há um balanço. Quanto aos fluxos noturnos observados no Pantanal, é ainda difícil estabelecer uma conexão entre o aumento dos fluxos noturnos, durante o alagamento, com a redução da produtividade. Possivelmente a resposta estaria no fato de que os ecossistemas alagados são muito complexos (Richey et al., 2002), onde, diferentemente dos sistemas secos, há transporte horizontal pelo fluxo hidrológico do carbono de outras áreas. Isto significa que o que se mede em uma área da ordem de $\sim 1 \mathrm{~km}$ pode resultar da fonte/área de outras áreas com funcionamento diferente. Isto quer dizer que simplesmente pode haver uma convergência ou divergência de fluxo de carbono para a área de observação torre pelo transporte hidrológico.

\subsection{Eficiência do uso da água e da radiação}

O funcionamento ecofisiológico de um ecossistema descreve a forma como um sistema biótico interage com o componente abiótico do ambiente. Portanto, pode-se afirmar que cada eco-sistema possuirá um conjunto único de mecanismos de interação com ambiente. Busca-se então, através de índices, formas de caracterização do ecossistema, como um sistema único, ou ao menos, como um padrão de funcionamento. 
A eficiência do uso da água (WUE) e a eficiência do uso de radiação (RUE) são índices que visam "caracterizar a capacidade de uma dada vegetação de utilizar os recursos disponíveis” (Moncrieff et al., 1997 b). Para interpretar, tanto WUE como o RUE, a diminuição (valores negativos) indica maior quantidade de $\mathrm{CO}_{2}$ absorvida pelo ecossistema, por quantidade de água utilizada na evapotranspiração ou por quantidade de irradiância PAR incidente. A redução destes parâmetros na verdade indica um aumento da eficiência biológica, à custa de ou limitada pelas perdas termodinâmicas.

\subsubsection{Eficiência do uso da água}

A variação de WUE na área de ecótono floresta-cerrado diminui com o início da inundação (Figura 29). Porém, após um período maior neste regime, volta a aumentar. Isto mostra que a variabilidade deste parâmetro segue exatamente a discussão feita na variabilidade do Albedo-PAR e dos fluxos de $\mathrm{CO}_{2}$ : uma sensibilidade do sistema à inundação, reduzindo a capacidade fotossintética; um atraso do ecossistema em responder (da ordem de 60 dias) ao estresse de anóxia na inundação; e finalmente a recuperação da capacidade após a inundação. 


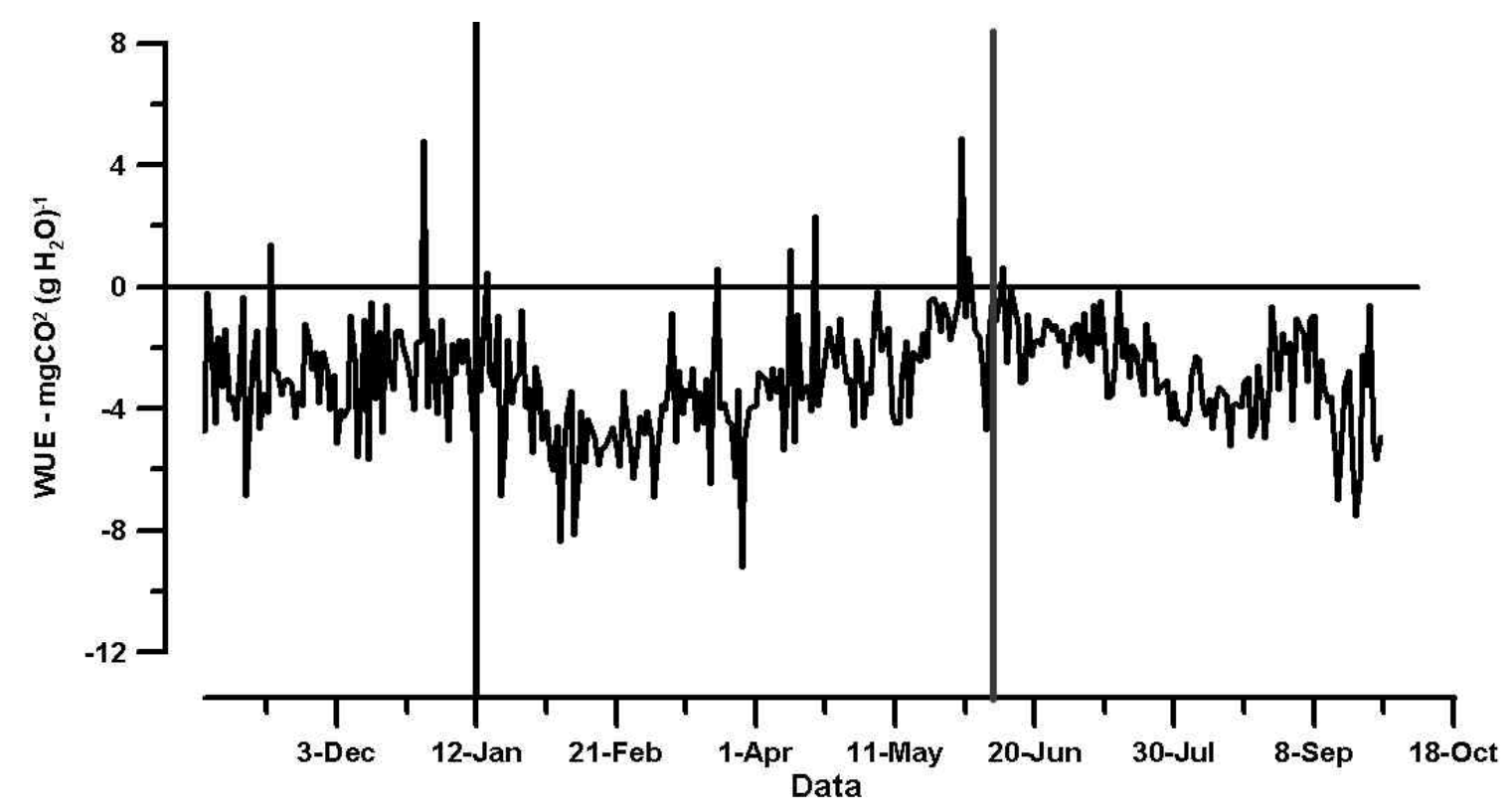

Figura 29- Média diária da Eficiência de uso da água (WUE), em mgCO $\left.\operatorname{mg~H}_{2} \mathrm{O}\right)^{-1}$, para o período de outubro de 2003 a junho de 2004, no sítio do ecótono Floresta-Cerrado. As barras verticais indicam o provável início e fim da inundação, respectivamente.

Comentando a Figura 29 em particular, no período que antecede à inundação, a WUE se manteve persistentemente na faixa de $4 \mathrm{mg} \mathrm{CO}_{2}\left(\mathrm{~g} \mathrm{H}_{2} \mathrm{O}\right)^{-1}$ de assimilação. $\mathrm{O}$ efeito da substituição do processo de respiração do solo, que atuava na fase seca, para um processo de evasão de $\mathrm{CO}_{2}$ sobre a superfície de água líquida, também pode ser observado no WUE. Um acentuado aumento ocorre na transição entre seca e inundação. Durante a inundação, o WUE apresentou uma tendência de acentuado aumento, culminando, no fim do período de alagamento, na alteração do estado funcional do sistema. Após o término da inundação ocorre uma recuperação nos valores de WUE, mesmo durante a fase seca. Porém, perto do fim de Agosto o estresse provocado pela ausência de chuvas pode ser observado.

A discussão, neste caso, apenas pretende abrir um espaço para o uso destes índices nas áreas alagáveis, e verificar o que é possível de se gerar como um real e novo entendimento. A limitação da utilização do cálculo de WUE neste caso é que ele não avalia a eficiência da vegetação, onde uma funcionalidade biológica inteligente e interativa estaria sendo contemplada. Para isso, deveria ser utilizado a transpiração do 
ecossistema, ao invés do fluxo de calor latente, que é um estimador tendencioso devido à presença de água livre no sistema. Por outro lado, a absorção de $\mathrm{CO}_{2}$, deve ser, na plena acepção do entendimento, a produtividade primária líquida, corrigida adequadamente pelos termos convenientes. Isto é possível com a utilização de eddy correlation, e poderá ser avaliado posteriormente.

A variação interanual do WUE no Cerrado (Figura 30) apresentou alguns padrões bastante interessantes. Em ambos os anos ocorre a alteração do estado funcional do sistema. Porém, no ano mais chuvoso (2002), o WUE é maior durante todo o ano. Os valores alcançados no auge da fase seca também foram notavelmente diferentes. No ano mais seco e mais frio (2001), as perdas de carbono foram maiores que os valores de assimilação. Observa-se desta forma que as discussões feitas na variabilidade interanual e intra-sazonal dos fluxos turbulentos de $\mathrm{CO}_{2}$ para o cerrado são exatamente aplicáveis no caso do parâmetro WUE. O que deverá ser aperfeiçoado na avaliação do padrão desta variável é a descrição mais realista dos fluxos de $\mathrm{CO}_{2}$ do ecossistema, fazendo-se a correção dos fluxos não-turbulentos.

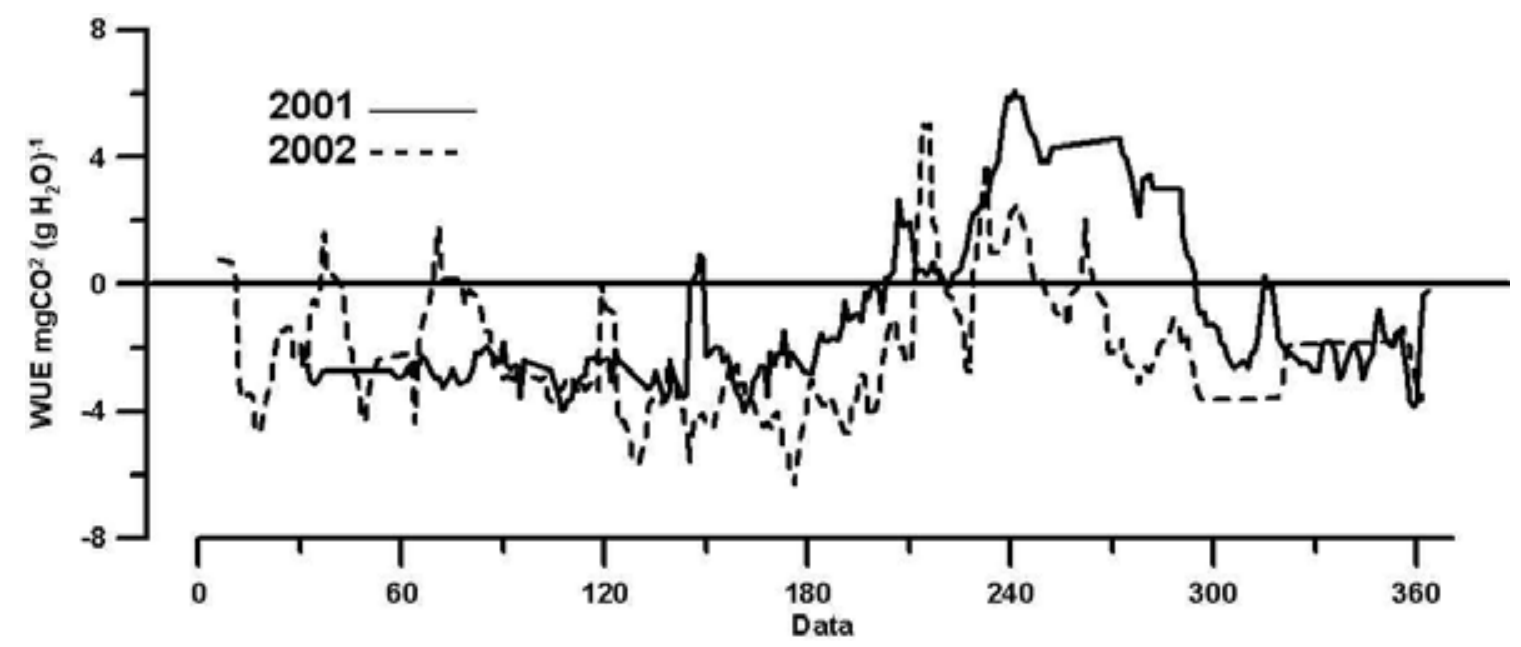

Figura 30 - Média (móvel) diária da Eficiência de uso da água (WUE), em mgCO $\left.\mathrm{H}_{2} \mathrm{O}\right)^{-1}$, para os anos de 2001, linha preta, e 2002, linha vermelha, no sítio do Cerrado seco 


\subsubsection{Eficiência do uso da radiação}

A eficiência do uso da radiação (RUE) descreve o fluxo de moléculas de $\mathrm{CO}_{2}$ por energia solar PAR absorvida.

A RUE do ecótono da Floresta-Cerrado (Figura 31) apresenta um aumento após a inundação, com um padrão de variabilidade também similar aos fluxos de $\mathrm{CO}_{2}$ e do Albedo-PAR. Com isso, o parâmetro RUE, descrito nesta forma, está sujeito à mesma interpretação de WUE. O que deverá gerar uma forma de mais entendimento neste parâmetro é a utilização da troca líquida do ecossistema, ao invés do fluxo turbulento.

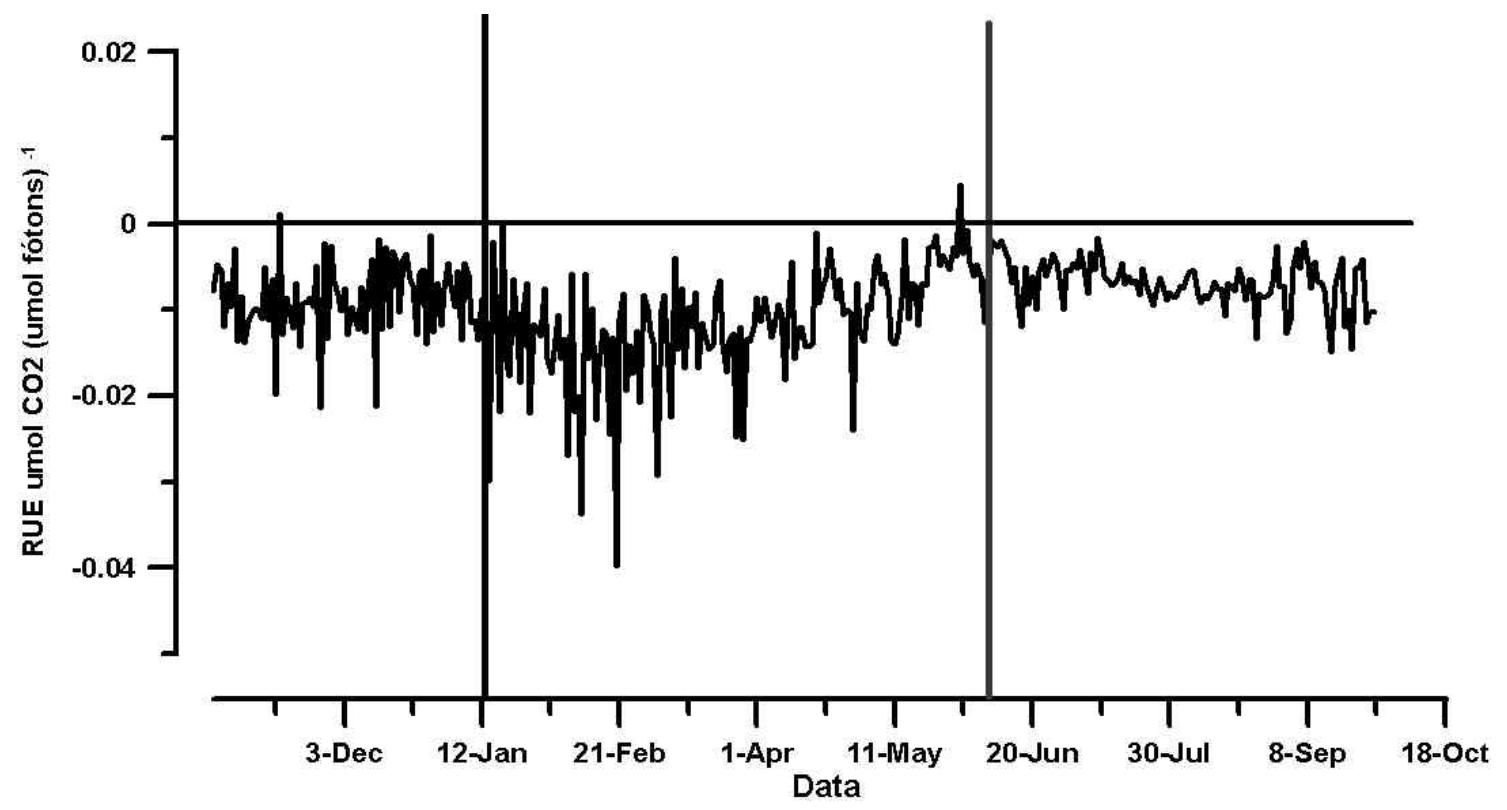

Figura 31 - Média diária da eficiência do uso da Radiação (RUE), para o período de outubro de 2003 a setembro de 2004, no ecótono Floresta-Cerrado, em $\mu \mathrm{mol}$ $\mathrm{m}^{-2} \mathrm{~s}^{-1}$ de $\mathrm{CO}_{2}\left(\mu \mathrm{mol} \text { PAR m} \mathrm{m}^{-2} \mathrm{~s}^{-1}\right)^{-1}$. As barras verticais indicam o provável início e fim da inundação, respectivamente.

Comparando o RUE do Cerrado (Figura 32) com a do ecótono (Figura 31) observa-se que durante o período chuvoso (mas sem o alagamento) o valor de RUE mínimo (ou máxima eficiência) dos dois sítios é apróximadamente 5 vezes maior no ecótono, igual a $-0,004 \mu \mathrm{mol} \mathrm{CO}_{2} \mathrm{~m}^{-2} \mathrm{~s}^{-1}\left(\mu \mathrm{mol} \text { PAR } \mathrm{m}^{-2} \mathrm{~s}^{-1}\right)^{-1}$ no Cerrado e $\sim-0,02$ $\mu \mathrm{mol} \mathrm{CO}_{2} \mathrm{~m}^{-2} \mathrm{~s}^{-1}\left(\mu \mathrm{mol} \text { PAR } \mathrm{m}^{-2} \mathrm{~s}^{-1}\right)^{-1}$ no ecótono, ou seja, a cada $1 \mu \mathrm{mol}$ de fótons PAR 
que chegam à superfície, cerca de 5 vezes mais $\mathrm{CO}_{2}$ é assimilado no ecótono do que no Cerrado s.s. Está diferença de eficiência pode ocorrer devido à área foliar. No ecótono a radiação é medida sobre uma formação florestal, com alto índice de área foliar, enquanto que no Cerrado s.s. os máximos de área foliar são geralmente menores.

A análise do ciclo anual do Cerrado Seco mostrou uma intensa sazonalidade. A diferença entre o ano de 2001 e 2002, não foi tão acentuada quanto o foi para o WUE, e quanto o foi para os fluxos de $\mathrm{CO}_{2}$ e Albedo-PAR. Este ponto é de fato notável, pois permite identificar neste parâmetro uma forma de avaliar a reação ou assinatura do ecossistema, independente da variabilidade interanual.

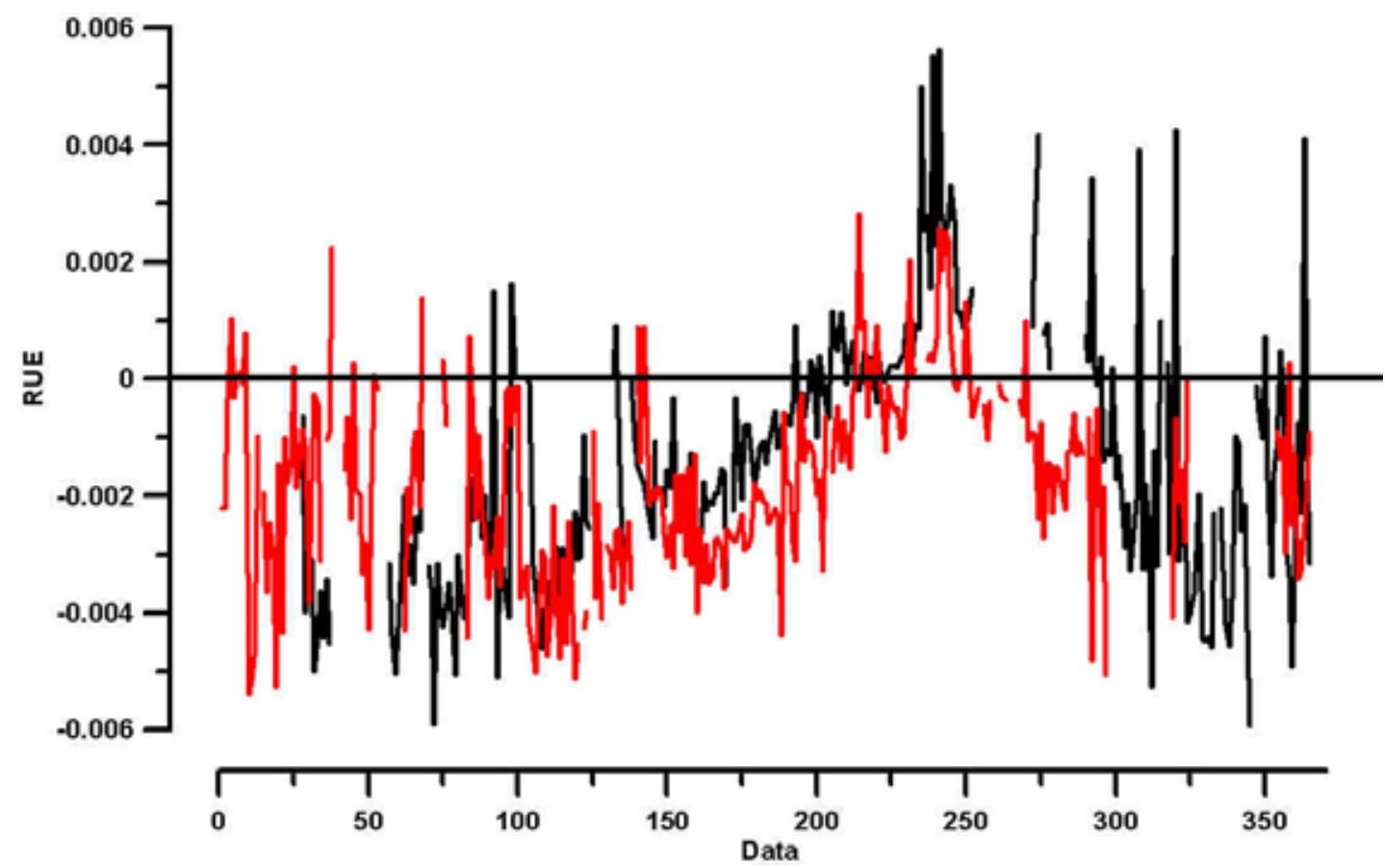

Figura 32 - Médias (móveis) diárias da eficiência do uso da Radiação (RUE), para os anos de 2001, linha preta, e 2002, linha vermelha, para o sítio do Cerrado seco, em $\mu \mathrm{molCO}_{2} \mathrm{~m}^{-2} \mathrm{~s}^{-1}\left(\mu \mathrm{mol} \text { PAR m} \mathrm{m}^{-2} \mathrm{~s}^{-1}\right)^{-1}$ 


\section{CONCLUSÕES}

De forma geral, nas latitudes subtropicais e particularmente nas regiões continentais brasileiras, concorrentemente com a redução da energia solar durante o inverno, também é neste período quando pronuncia-se a estação seca. Assim a redução da evapotranspiração e da fotossíntese ocorrem pelo efeito da redução do fotoperíodo e do estresse hídrico. Não é uma tarefa trivial separar os dois fatores, pois o ecossistema deve estar adaptado à influência dos dois controles através de ritmos biológicos de causa evolutiva. Esta reflexão é particularmente aplicável no caso do Cerrado s.s. Mais além, quando trata-se do ecótono floresta-cerrado, que é alagado sazonalmente, a anóxia mostra como o outro fator de estresse que compõe o conjunto de influências no funcionamento ecológico. A discussão deste estudo pretendeu trazer novas e mais detalhadas informações para se aprofundar este tipo de entendimento.

A análise dos dados micrometeorológicos sobre as áreas experimentais de ecótono Floresta-Cerrado e do Cerrado s.s. sugerem alguns pontos a reforçar para fins de análise comparativa:

(i) $\mathrm{O}$ ecótono e o Cerrado estão sob solos arenosos, homogêneos e com alta capacidade de infiltração e drenagem. A baixa capacidade de armazenamento de água força, de alguma forma, que haja uma resposta rápida da vegetação a um déficit hídrico. Neste caso, ocorrem senescência das folhas e dormência das gramíneas. Por outro lado, facilitando a drenagem, a recarga da camada do sistema radicular é mais eficiente na transição para a estação chuvosa, o que facilitaria a rebrota; 
O Cerrado s.s. mostrou-se um ecossistema com forte sazonalidade da capacidade fotossintética, mostrados por uma variabilidade sazonal coerente do Albedo-PAR e dos fluxos atmosféricos de $\mathrm{CO}_{2}$. Há uma fase de sumidouro e outra de fonte de $\mathrm{CO}_{2}$, corroborando os dados da literatura (Rocha et al., 2002; Vourlitis et al., 2001; Miranda et al., 1997) ;

(iii) Na escala da variabilidade interanual, a variação do estado funcional do Cerrado como sumidouro ou fonte de $\mathrm{CO}_{2}$ são fortemente dependentes das variações do regime pluviométrico e da temperatura mínima.

(iv) No ecótono Floresta-Cerrado, a fase de inundação induz à uma diminuição gradual da respiração do sistema e da produtividade primária;

(v) a diminuição na produtividade ocorre com um atraso de $\sim 45$ dias, que poderia ser um tempo de assimilação e tolerância do sistema ao estresse induzido por anóxia;

(vi) a redução da respiração do ecossistema ocorre ao passo que no regime alagado as perdas de CO2 ocorrem por evasão da superfície de água livre, um processo que aparentemente tem uma fonte de emissão menor que os processos de respiração do solo em condições secas, na mesma área;

(vii) Durante a maior parte da inundação o ecótono continua a manter-se como um sumidouro de $\mathrm{CO}_{2}$ atmosférico durante, ao menos, 3 meses.

(viii) Como fonte de estresse, a inundação possui efeitos menos severos que a seca para os fluxos de $\mathrm{CO}_{2}$;

(ix) O tempo de resposta do ambiente, seja no Cerrado s.s. ou no ecótono, ao estresse hídrico, é bem maior do que o tempo de resposta à inundação (no 
caso do ecótono), ou no caso do Cerrado s.s, ao aumento da umidade (rebrota);

(x) O parâmetro RUE do ecótono foi cerca de 5 vezes maior do que o do Cerrado. A diferença de eficiência se deve possivelmente ao maior índice de área foliar das formações florestais da transição Floresta-Cerrado;

(xi) A funcionalidade é controlada por fatores ambientais de maior escala que as locais. No caso do Cerrado s.s. há uma forte dependência do regime de chuvas e da temperatura mínima. No caso do ecótono Floresta-Cerrado, a suscetibilidade parece ser uma função do tempo de inundação.

Algumas considerações tem sido feitas sobre a possibilidade de savanização da Amazônia, resultante da diminuição da precipitação na área bacia (Nobre et al., 1991; Oyama 2002). Para isso, são feitos alguns comentários, uma vez que este tudo trata essencialmente sobre os cerrados. Toda análise envolvendo organismos vivos só faz efetivamente sentido perante a luz dos processos evolutivos. Os dois mecanismos básicos da seleção natural são a seleção e a competição. Toda vez que ocorre uma mudança ambiental, os indivíduos são testados pelo novo ambiente. Os indivíduos aptos sobrevivem e se reproduzem na nova condição.

Os indivíduos, populações, comunidades e biomas competem, interna e externamente, por recursos e pela sua reprodução. As alterações ambientais provocadas pelo homem podem levar a uma alteração no equilibrio competitivo entre dois biomas e as consequências deste desequilíbrio são incertas. A dinâmica entre os biomas Floresta e Cerrado alterou-se com o passar das epócas geológicas, devido às alterações de grande escala no clima (Ab'Saber, 1982). Porém os biomas enfrentam uma nova situação, as alterações de menor escala como o desmatamento e de maior escala como o aquecimento global estão alterando, ou na iminência de alterar, o equilibrio entre Floresta e Cerrado. 
O entendimento do funcionamento ecológico do ecótono Floresta-Cerrado, do bioma Cerrado e da forma de interação destes biomas com o componente abiótico irão permitir uma avaliação mais profunda da possibilidade de mudança no equilibrio Floresta-Cerrado.

A literatura reporta que a Floresta possui uma maior plasticidade pedológica, existindo em solos ricos e pobres, enquanto que o Cerrado limita-se aos solos pobres (Sarmiento, 1984). Provavelmente, isto se deve-se mais à uma questão de competição entre os biomas, do que um problema de toxicidade. Devido a esta vantagem competitiva, e ao aumento de umidade, o ambiente tem favorecido a Floresta, após a ultima glaciação (Prance, 1982). Análises de componentes da vegetação indicam que a Floresta veio crescendo sobre o dominio dos Cerrados, na escala de milênios (Ratter, 1992). Esta teria sido uma tendência estabelecida pelos fenômenos naturais de grande escala, antes da interferência antrópica nos últimos séculos.

Um eventual aumento da sazonalidade no clima da Floresta Amazônica pode alterar o equilibrio Floresta-Cerrado. A compreensão do funcionamento e da dinâmica das savanas na América do Sul, e consequentemente dos Cerrados, é atrelada de forma fundamental à expressão sazonalidade (Sarmiento, 1984). Provavelmente, se ocorrer um aumento de sazonalidade, o equilibrio será alterado a favor da vegetação mais adaptada à ela, no caso o Cerrado.

O desmatamento associado às frequentes queimadas realizadas por amerindios na Venezuela levaram a uma degradação do solo, tal que permitiu com que o Cerrado invadisse o domínio da floresta em determinados locais (Cavelier et al., 1998). Isto pode se repetir em grande escala, como os pastos abandonados e as áreas sujeitas às queimadas frequentes.

O cerrado apresenta adaptações ao fogo, tanto reprodutivas, quanto competitivas. Os incêndios são mais vantajosos para o estrato herbáceo, dentre as inúmeras adaptações ao fogo. A principal é o eficiente sistema de absorção de nutrientes na camada superfial (Coutinho, 1990). A maior frequência de incêndios iria favorecer ao Cerrado.

Por outro lado, o efeito de um possível aumento do período de inundação no equilíbrio Floresta-Cerrado permanece incógnito. Ao mesmo tempo que diversas 
espécies amazônicas são altamente adaptadas à inundação (Jolly, 1991; Junk, 1991), o Cerrado, no caso especial das savanas hipersazonais (Sarmiento, 1984), também apresenta resistência e adaptação à inundação.

Embora ainda sejam enormes as incertezas sobre a variação de precipitação na América do Sul, decorrente do aquecimento global, alguns cenários do clima, até 2050, apontam para um aumento da chuva na região do Tocantins, o que, numa associação direta, poderia levar ao aumento da inundação. Também aponta para uma diminuição da chuva na região do Mato-Grosso (Silva \& Avissar, 2004). Está alteração do regime pluviométrico pode afetar de forma diferente o equilibrio Floresta-Cerrado. No Mato Grosso o Cerrado poderia crescer devido à melhor capacidade de lidar com a sazonalidade pluviométrica, enquanto que no Tocantins poderia haver um crescimento do Cerrado hipersazonal devido à uma (suposta) melhor adaptação à inundação, pelo menos nas áreas próximas da ilha do Bananal. O real efeito da alteração da precipitação sobre o equilibrio Floresta-Cerrado depende não apenas do total de precipitação anual, mas também da sazonalidade da precipitação, o que comentaria Silva \& Avissar (2004).

Considerando a veracidade da teoria dos refúgios (Haffer, 1982), mesmo que ocorra uma mudança no clima Amazônico devido ao desmatamento e/ou ao aquecimento global, o Cerrado não invadiria toda a floresta. Provavelmente, grandes aglomerados de florestas se concentrariam nas áreas próximas aos rios, isto é, nas áreas com maior umidade. Como existem diferentes tipos de formações florestais, também não fica excluida a hipótese de uma substituição de fisionomias florestais. Com isto, o mapa de fertilidade do solo e de topografia da Amazônia deve ser, igualmente aos cenários climáticos, levado em conta nas estimativas de migração dos biomas. 


\subsection{Sugestões para trabalhos futuros}

- Fazer um estudo com mais profundidade da dependência do Albedo-PAR com a variabilidade de umidade do solo e índice de área foliar, neste último caso através de medidas;

- Aprofundar a discussão das perdas de CO2 na fase alagada do ecótono, com medidas de evasão da água;

- Realizar um inventário de espécies e caracterização dos biomas na área experimental do ecótono; 


\section{REFERÊNCIAS BIBLIOGRÁFICAS}

ALVALÁ, P.; VON RANDOW, C.; MANZI, A.O.; SOUZA, A.; SÁ L.; ALVALÁ, R. $\mathrm{CO}_{2}$ fluxes over pantanal region under dry and flood condition. In: CONGRESSO CIENTÍFICO DO LBA, Brasília, 2004.

http://www.lbaconferencia.org/Livro_Resumos.pdf (03 nov. 2004).

ARAUJO NETO, M.D. DE; FURLEY, P.A.; HARIDASAN, M.; JONHSON, C.E. The murundus os cerrado region of central Brazil. Journal of Tropical Ecology, v.1, p.17-35, 1986.

ARMSTRONG, W.; BRÄNDLE R.; JACKSON M.B. Mechanisms of flood tolerance in plants. Acta Botanica Neerlandica, n.43, v.4, p.307-358, 1994.

AZIZ NACIB AB'SABER. The paleoclimate and paleoecology of brazilian amazon. In: PRANCE G.T. (Ed.). Biological diversification in the tropics. New York: Columbia University Press, 1982. p. 41-60.

BATALHA, M.A. Análise da vegetação da ARIE Cerrado Pé-de-Gigante (Santa Rita do Passa Quatro, SP). São Paulo, 1997. 185 p. Dissertação (Mestrado) - Instituto de Biociências, Universidade de São Paulo.

CAMPBELL SCIENTIFIC. CS615 Water Content Reflectometer Instruction Manual, Logan: Campbell Scientific, 1996. 12 p. 
CABRAL, O.M.R.; ROCHA, H.R.; LIGO, M.A.V.; BRUNINI, O.; SILVA DIAS, M.A.F. Fluxos turbulentos de calor sensível, vapor de água e $\mathrm{CO}_{2}$ sobre plantação de cana-de-açúcar (Saccharum sp.) em Sertãozinho-SP. Revista Brasileira de Meteorologia, v.18, n.1, p.61-70, 2003.

COUTINHO, L.M. O conceito de cerrado. Revista Brasileira de Botânica v.1, p.17-23, 1978.

COUTINHO, L.M. Fire in the ecology of the brazilian cerrado. Ecological Studies v.48, p.82-105, 1990.

CASTRO, E.A.; KAUFFMAN, J.B. Ecosystem structure in the brazilian cerrado: a vegetation gradient of aboveground biomass, root mass and consumption by fire. Journal of Tropical Ecology, v.14, p.263-283, 1998.

DEZZEO, N.; WORBES, M.; ISHII, I.; HERRERA, R. Annual tree rings revealed by radiocarbon dating in seasonally flooded forest of the Mapire river, a tributary of the lower Orinoco River, Venezuela. Plant Ecology, v.168, p.165-175, 2003.

EDEN, M.J.; MCGREGOR, F.M. Dynamics of forest-savanna boundary in the rio Branco-Rupununi region of northern Amazonia. In: FURLEY, P.A.; PROCTOR, J.; RATTER, J.A. (Ed.). Nature and dynamics of forest-savanna boundaries. London: Chapman \& Hall, 1992. p. 417-427.

FURLEY, A.P. Edaphic changes at the Forest-savanna boundary with particular reference to the neotropics. In: FURLEY, P.A.; PROCTOR, J.; RATTER, J.A. (Ed.). Nature and dynamics of forest-savanna boundaries. London: Chapman \& Hall, 1992. p. 91-115. 
GOODLAND, R.; POLLARD, R. The brazilian cerrado vegetation: a fertility gradient. Journal of Ecology, v.61, p.219-224, 1973.

GOULDEN, M.L.; MUNGER, J.W.; FAN, S.M.; DAUBE, B.C.; WOFSY., S.C. Measurements of carbon sequestration by long-term eddy covariance: Methods and a critical evaluation of accuracy. Global Change Biology, v.2, p.169-182, 1996.

GOULDEN, M.L.; MILLER, S.D.; MENTON, M.C.; ROCHA, H.R.; FREITAS, H.C. Diel and seasonal patterns of tropical forest $\mathrm{CO}_{2}$ exchange. Ecological Applications, v.14, p.S42-S54, 2004. (supl 4).

GUNDERSON, L.; HOLLING, C.S.; PRITCHARD, L.; PETERSON, G.D. Resilience. In: MUNN, T. Encyclopedia of global enviromental change, v. 2, p.530-531, 2002.

HARIDASAN, M. Observation on soils, folia nutrient concentration and floristic composition of cerrado sensu stricto and cerradão communities in central Brazil. In: FURLEY, P.A.; PROCTOR, J.; RATTER, J.A. (Ed.). Nature and dynamics of forest-savanna boundaries. London: Chapman \& Hall, 1992. p.171-182.

HARIDASAN, M. Nutrição mineral de plantas nativas do cerrado, Revista Brasileira de Fisiologia Vegetal, v.12, n.1, p.54-64, 2000.

INSTITUTO BRASILEIRO DE GEOGRAFIA E ESTATíSTICA (IBGE). Mapa da vegetaçã do Brasil 2004 - (1:5.000.000) - www.ibge.gov.br (19 out. 2004).

INTERNATIONAL PANEL FOR CLIMATE CHANGE (IPCC) 2001: Synthesis report. WATSON, R.T. and the core writing (Ed.), Genebra: IPCC, 2001. 184p. 
JOLY, C.A. Flooding tolerance in tropical trees. In: JACKSON, M.B.; DAVIES, M.B.; LAMBERS H. (Ed.). Plant life under oxygen deprivation. Holanda: Academic Publish, 1991. p.23-34.

JUNK ,W. J. Flood tolerance and tree distribution in central amazonian floodplains. In: HOLM-NIELSEN, L.B.; NIELSEN, I.C.; BALSLEV, H. (Ed.). Tropical Forests: Botanical dynamics, speciation and diversity. London: Academic Press, 1989. p.4764.

LARCHER, W. Ecofisiologia vegetal. Rio de Janeiro: Rima, 2000. 531 p.

LEDRU, M.P. Late quaternary history and evolution of the cerrados as revealed by palynological records. In: OLIVEIRA, P.S.; MARQUIS, R.J. (Ed.). The cerrados of Brazil, ecology and natural history of a neotropical savanna. New York : Columbia University Press, 2002. p.33-51.

LEUNING, R.; MONCRIEFF, J. Eddy-covariance $\mathrm{CO}_{2}$ flux measurements using open and closed path $\mathrm{CO}_{2}$ analyzers: Corrections for analyzers water vapor sensitivity and damping of fluctuations in air sampling tubes. Boundary-Layer Meteorology, v.53, p.63-76, 1990.

LIEBETHAL, C.; FOKEN, T. On the significance of the Webb correction to fluxes. Boundary-Layer Meteorology, v.109, p.99-106, 2003.

NEVES, W.A.; PROUS, A.; GONZÁLES-JOSÉ, R. ;KIPNIS,R.; POWELL J. Early Holocene human skeletal remains from Santana do Riacho: implications for the settlement of the New World. Journal of Human Evolution, v.45, p.19-42, 2003.

NOBRE, C.; SELLERS, P.J.; SHUKLA J. Amazonian deforestation and regional climate. Journal of Climate, v.4, p.957- 988, 1991. 
MAIA, J.M.F. Balanço de energia e fluxo de carbono em uma área de cerrado que sofreu queima acidental. Brasilia, 2003. 165p. Tese (Doutorado) - Instituto de Ciências Biológicas, Universidade de Brasilia.

MIRANDA, A.C.; MIRANDA, H.S. ; LLOYD, J. ; GRACE, J. ; MCINTYRE, J.A. ; MEIR, P.; RIGGAN, P.; LOCKWOOD, R.; BRASS, J. Carbon dioxide fluxes over a cerrado Sensu Stricto in central Brazil. In: GASH, J.C.H.; NOBRE, C.A.; ROBERTS, J.M.; VICTÓRIA R. (Ed.). Amazon deforestation and climate. Chichester: John Wiley, 1996. p. 353-364.

MIRANDA, A.C.; MIRANDA, H.S.; LLOYD, J.; GRACE, J.; FRANCEY, R.J.; MCINTYRE, J.A.; MEIR, P.; RIGGAN, P.; LOCKWOOD, R.; BRASS, J. Fluxes of carbon, water and energy over Brazilian cerrado: an analysis using eddy covariance and stable isotopes. Plant, Cell and Environment, v.20, p.315-328, 1997.

MIRANDA, H.S.; BUSTAMANTE, M.M.C.; MIRANDA, A.C. The fire factor. In: OLIVEIRA, P.S.; MARQUIS, R.J (Ed.). The cerrados of Brazil, ecology and natural history of a neotropical savanna. New York: Columbia University Press, 2002. p.51-68.

MONCRIEFF, J.B.; MASSHEDER, J.M. ; BRUIN, H. DE; ELBERS, J. ; FRIBORG, T.; HEUSINKVELD, B.; KABAT, P.; SCOTT, S.; SOEGAARD, H. ; VERHOF, A. A system to measure surface fluxes of momentum, sensible heat, water vapor and carbon dioxide. Journal of Hydrology, v.189, p.589-611, 1997 a.

MONCRIEFF, J.B.; MONTENY, B.; VERHOEF, A.; FRIBORG ,TH.; ELBERS, J.; KABAT, P.; BRUIN, H.DE ; SOEGAARD, H.; JARVIS, P.G.; TAUPIN, J.D. Spatial and temporal variations in net carbon flux during HAPEX-Sahel. Journal of Hydrology, v.188/189, p.563-588, 1997 b. 
MOTTA, P.E.F.; CURI, N.; FRANZMEIER D.P. Relation of soils and geomorphic surfaces in the brazilian cerrado .In: OLIVEIRA, P.S.; MARQUIS, R.J. (Ed.). The cerrados of Brazil, ecology and natural history of a neotropical savanna. New York: Columbia University Press, 2002. p.13-33.

MULLER, F. State-of-the-art ecosystem theory. Ecological Modelling, v.100, p.135$161,1997$.

MYERS, N.; MITTERMEIER, R.A.; MITTERMEIER, C.G.; FONSECA, G.A.B. DA; KENT, J. Biodiversity hotspots for conservation priorities in Nature v.403 , n. 24, p.853- 858, 2000.

JUAREZ, R.I.N. Variabilidade climática regional e controle da vegetação no sudeste: um estudo de observações sobre cerrado e cana-de-açúcar e modelagem numérica da atmosfera. São Paulo, 2004. 159 p. Tese (Doutorado) - Instituto de Astronomia, Geofísica e Ciências Atmosféricas, Universidade de São Paulo.

OLIVEIRA-FILHO, A.T.; RATTER, J.A. Vegetation physiognomies and woody flora of the cerrado biome. In: OLIVEIRA, P.S.; MARQUIS, R.J. (Ed.). The cerrados of Brazil, ecology and natural history of a neotropical savanna. New York :

Columbia University Press, 2002. p.91-121.

OYAMA, M.D. Consequências climaticas das mudança de vegetação do nordeste brasileiro: um estudo de modelagem. São José dos Campos, 2002. 220 p. Tese (Doutorado) Instituto Nacional de Pesquisas Espaciais (INPE).

PRANCE, G.T. The refuge theory In: PRANCE G.T. (Ed.). Biological diversification in the tropics. New York: Columbia University Press, 1982. p 3-6. 
RATTER, J.A. Transitions between cerrado and forest vegetation in Brazil. In: FURLEY, P.A.; PROCTOR, J.; RATTER, J.A. (Ed.). Nature and dynamics of forest-savanna boundaries. London: Chapman \& Hall, 1992. p.417-427.

RAWITCHER F. The water economy of the vegetation of the "campos cerrados" in southern Brazil. Journal of Ecology, v.36, p.238-268, 1948.

RIEHL, H. Climate and weather in the tropics. London: Academic Press, 1979. 530 p.

RIBEIRO, J.F.;WALTER, B.M.T. Fitofisionomias do bioma cerrado. In: SANO, S.M.; ALMEIDA, S.P. Cerrado ambiente e flora. Brasilia : Editora Embrapa, 1998. p.89-166.

ROCHA, H.R.; FREITAS H.C.; ROSOLEM R.; JUAREZ R.I.N.; TANNUS R.N.; LIGO M.A.; CABRAL O.M.R.; DIAS M.A.F.S. Medidas de fluxos de $\mathrm{CO}_{2} \mathrm{em}$ um CerradoSensu stricto no sudeste do Brasil. Biota Neotropica, v.2, n.1, 2002. http://www.biotaneotropica.org.br/v2n1/pt/item?article (03 nov. 2004).

ROCHA, H.R.; GOULDEN, M.L.; MILLER, S.D.; MENTON, M.C.; PINTO, L.D.V.O.; FREITAS, H.C.; FIGUEIRA, A.M.S. Seasonality of water and heat flux over a tropical forest in eastern Amazonia. Ecological Application, v.14, p.S22S32, 2004. (supl. 4).

ROCHA, H.R.; FREITAS, H.C.; ROSOLEM, R.; TANNUS, R.N.; JUAREZ, R.I.N.; LIGO, M.V.; CABRAL, O.M.R.; MESQUITA, H.; BITTENCOURT, M. Ciclo hidrológico e microclima. In: PIVELLO V.R.; VARANDA, E.M. (Ed.). O Cerrado Pé de Gigante - Ecologia e Conservação. São Paulo: Imprensa Oficial do Estado de São Paulo. 2004 a. p. 70-89. 
RUGGIERO, P.G.C.; BATALHA, M.A.; PIVELLO, V.R.; MEIRELLES, S.T. Soilvegetation relationships in cerrado (Brazilian savanna) and semideciduos forest, Southeastern Brasil. Plant Ecology, v.160, p.1-16, 2002.

RYCHEY, J.E.; MELACK, J.M.; AUDFDENKAMPE, A.K.; BALLESTER,V.M.; HESS, L.L. Outgassing from Amazonian rivers and wetlands as a large tropical source of atmospheric $\mathrm{CO}_{2}$. Nature, v.416, p.617-620, 2002.

SARMIENTO, G. The ecology of tropical savannas. Massachusetts: Harvard University Press, 1984. 235 p.

SILVA, R.R.DA; AVISSAR, R. Impacts of land-cover change on the hydrometeorology of the Amazon. In: CONGRESSO CIENTÍFICO DO LBA, Brasília, 2004. http://www.lbaconferencia.org/Livro_Resumos.pdf (03 nov. 2004).

STULL , R. B. An Introduction to boundary layer meteorology. Holanda: Kluwer Academic Publishers, 1984. 665p.

SCHWARTZ, P.; RANDALL, D. An abrupt climate change scenario and its implications for United States National Security (relatório para a agência de segurança nacional dos Estados Unidos) 2003. http://www.gbn.org/ArticleDisplayServlet.srv?aid=26231 (3 nov. 2004)

VON BERTALANFLY, L. Teoria geral dos sistemas. Rio de Janeiro: Editora Vozes, 1968, 352 p. 
VON RANDOW, C.; MANZI ,A.O.; KRUIJT ,B. ; OLIVEIRAS, P.J; ZANCHI, F.B.; SILVAS, R.L.; HODNETT, M.G.; GASH, H.C.; ELBERS, J.A.; WATERLOO, M. J.; CARDOSO, F.L.; KABAT, P. Comparative measurements and seasonal variations in energy and carbon exchange over forest and pasture in south west Amazonia. Theoretical and Applied Climatology, v.78, n.1/3, p.5-26, 2004.

VOURLITIS, G.; PRIANTE FILHO, N.; HAYASHI, M.M.S.; NOGUEIRA, J.S.; CASEIRO, F.T. ; CAMPELO JR ,J.H. Seasonal variations in the net ecosystem $\mathrm{CO}_{2}$ exchange of a mature amazonian transitional tropical forest (cerradão). Functional ecology, v.15, p.338-395, 2001.

WALTER, H. Vegetação e zonas climáticas. São Paulo: Editora Pedagógica Universitária, 1970. 325 p.

WIEGAND, T.; SNYMAN, H.A.; KELLNER, K.; PARUELO, J.M. Do grassland have a memory: Modelling phytomass production of a semiarid south african grassland. Ecosystem, v.7, p.253-248, 2004. 


\section{APÊNDICES}




\section{APÊNDICE 1 - Efeito das Correções de Webb e Correção de Riehl nos Fluxos de superfície do ecótono Floresta-Cerrado}

Descreve-se aqui a correção de Riehl para o fluxo de calor sensível e a correção de Webb para os fluxos de $\mathrm{CO}_{2}$ e de calor latente. $\mathrm{O}$ valor aproximado da correção de Riehl (Figura 33) sobre o oceano tropical é equivalente a 10\% do valor do fluxo de calor latente para uma temperatura próximas de 300K, segundo Riehl (1979). O valor encontrado para a área de ecótono Floresta-Cerrado ficou um pouco abaixo deste valor no período que antecedeu a inundação, e durante a inundação ficou entre 10 e $20 \%$.

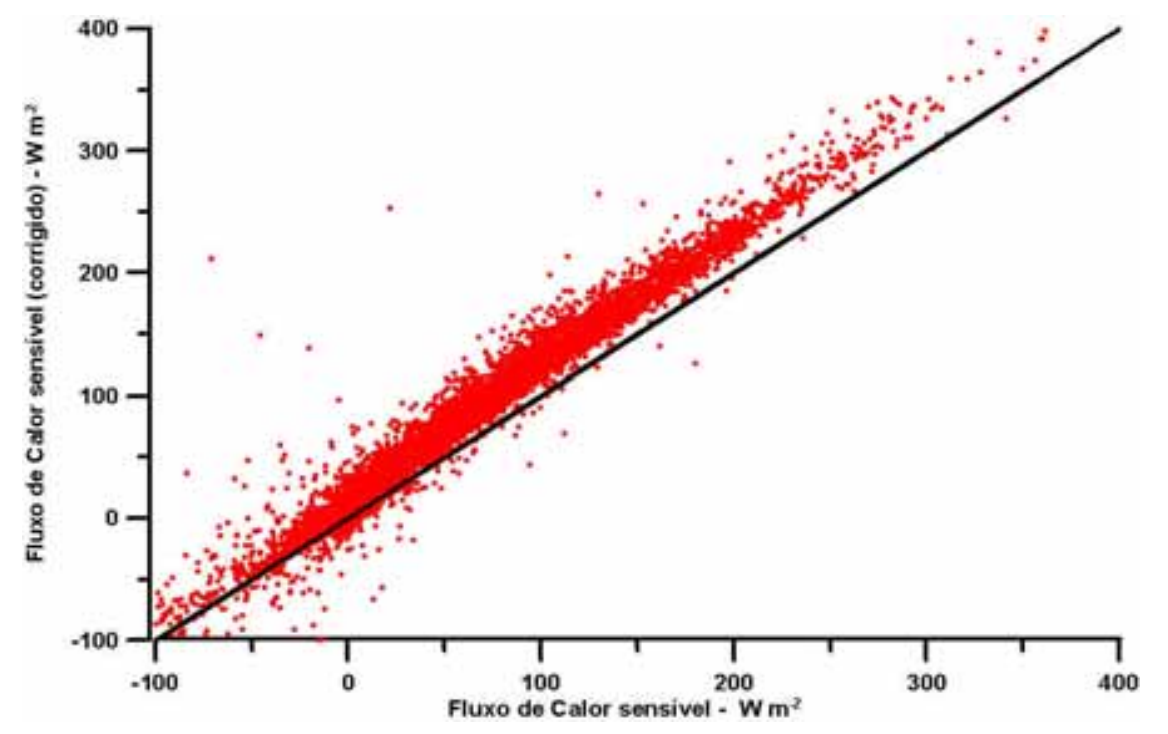

Figura 33 - Fluxo de Calor sensível com a correção de Riehl versus Fluxo de Calor sensível sem a correção de Riehl, em $\mathrm{Wm}^{-2}$. Sítio do ecótono FlorestaCerrado.

O efeito da correção de Webb para o fluxo de calor latente foi de aproximadamente 1,5\% (Figura 34) em todo o período de estudo. Estes dados concordam com os encontrados na literatura que apontam para uma correção de 1 a 5 \% (Liebethal \& Foken, 2003) 


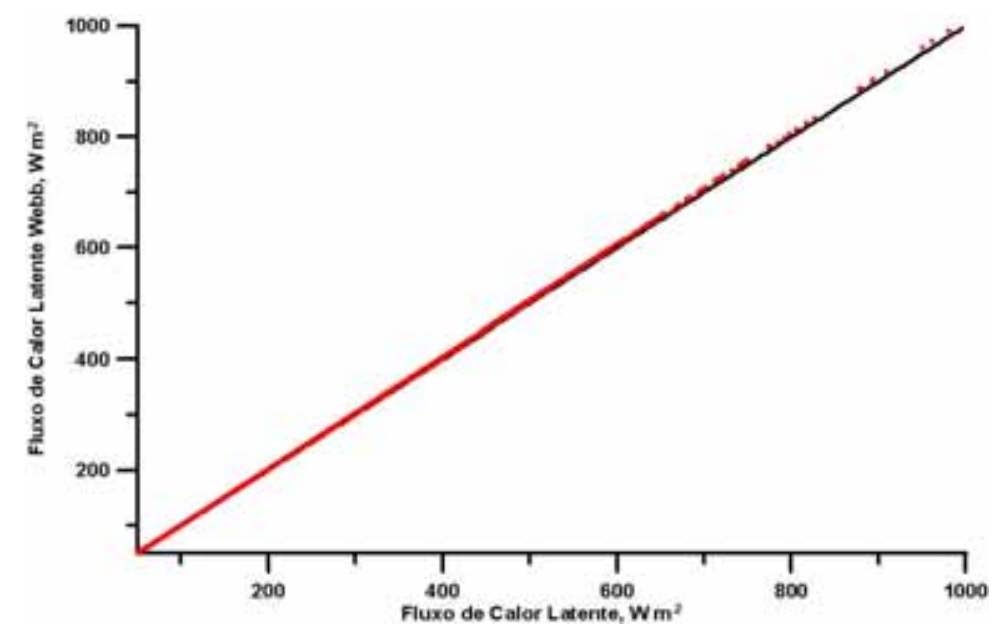

Figura 34 - Fluxo de calor latente com a correção de Webb versus Fluxo de calor latente sem a correção de Webb. Para o sítio do ecótono Floresta-Cerrado

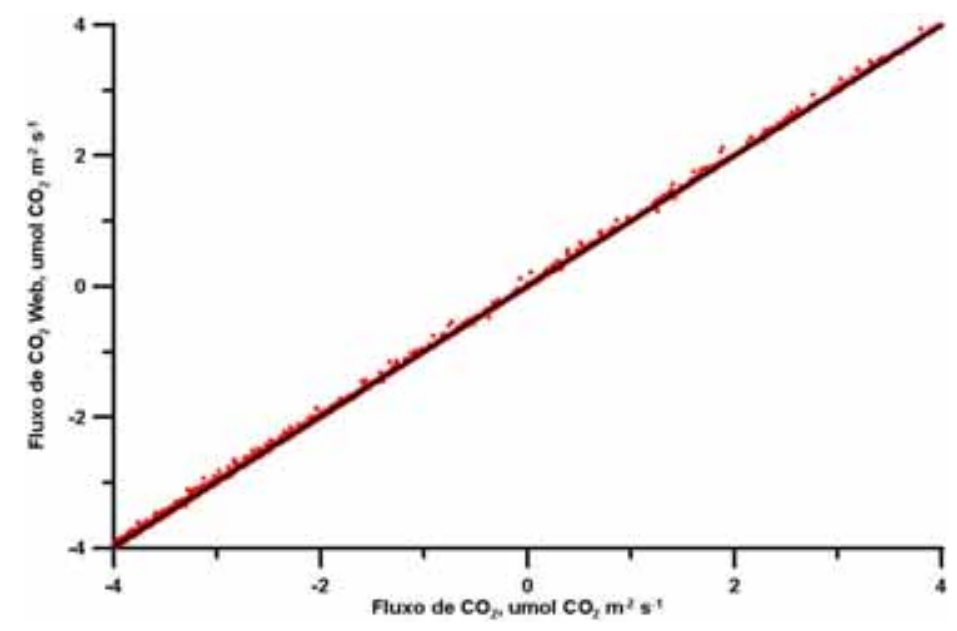

Figura 35 - Fluxo de $\mathrm{CO}_{2}$ corrigido versus fluxo de $\mathrm{CO}_{2}$ sem correção. Ambos em $\mu \mathrm{mol}$ $\mathrm{CO}_{2} \mathrm{~m}^{-2} \mathrm{~s}^{-1}$. Para o sítio do ecótono Floresta-Cerrado

O efeito da correção de Webb descrito na literatura é de 5 a 20\% (Liebethal \& Foken, 2003). A diferença promovida pela correção foi de aproximadamente 10\%, sendo o efeito da correção maior nos fluxos de pequeno valor, isto é, menor que $4 \mu \mathrm{mol} \mathrm{CO}_{2}$ $\mathrm{m}^{-2} \mathrm{~s}^{-1}$ (Figura 35). 


\section{APÊNDICE 2 - Balanço de energia}

O fechamento do balanço de energia é uma comparação entre os fluxos de energia medidos pelos sistema de eddy correlation (LE e Hs) e os fluxos de energia com o saldo Radiômetro (Rn) e os fluxímetros de solo (G) .O fechamento do balanço de energia no sítio do Cerrado s.s. foi de $\sim 75 \%$ (Juarez, 2004). Na área de ecótono o fechamento foi razoavelmente superior, de $\sim 88 \%$ (sem correção de Riehl e Webb) e 92\% (com correção de Riehl e Webb).

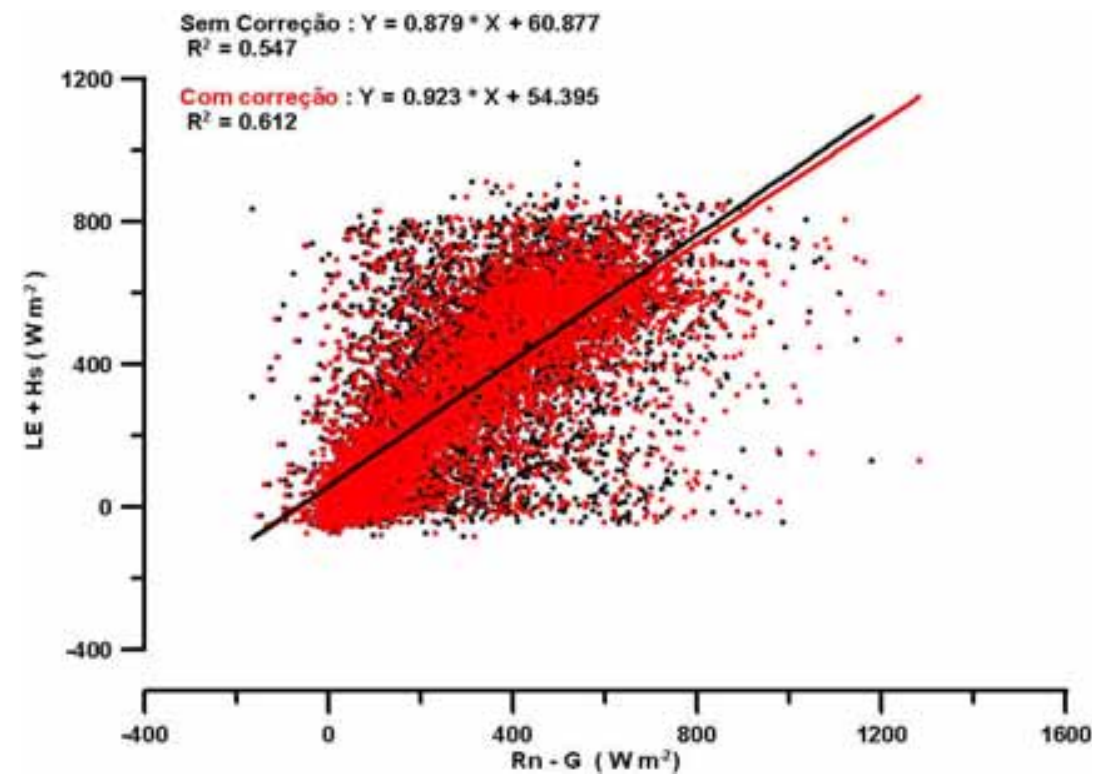

Figura 36 - Fechamento do balanço de energia para o sítio do ecótono Floresta-Cerrado, para o período de outubro de 2003 a setembro de 2004. Os pontos pretos eferem-se aos fluxos sem correções. Os pontos vermelhos vermelhos referem-se aos fluxos com a correção de Riehl e Webb 


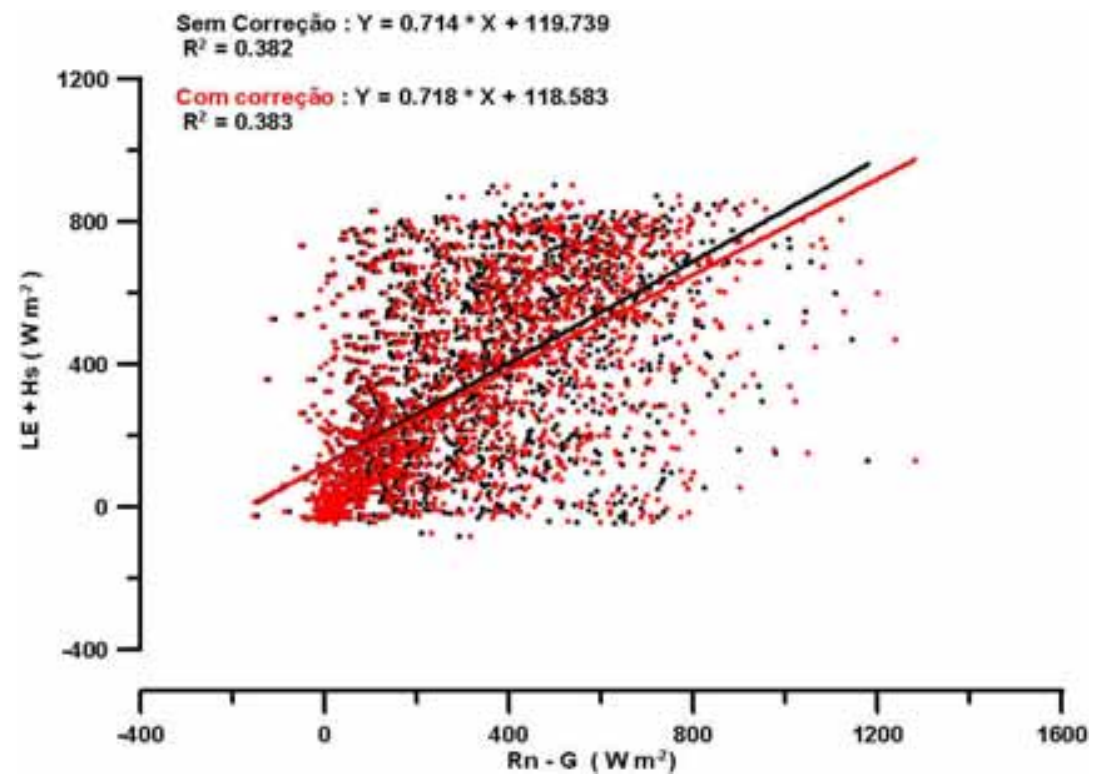

Figura 37 - Fechamento do balanço de energia para o sítio do ecótono Floresta-Cerrado, para o período de outubro de 2003 a janeiro de 2004. Período Préalagamento. Os pontos pretos eferem-se aos fluxos sem correções. Os pontos vermelhos vermelhos referem-se aos fluxos com a correção de Riehl e Webb

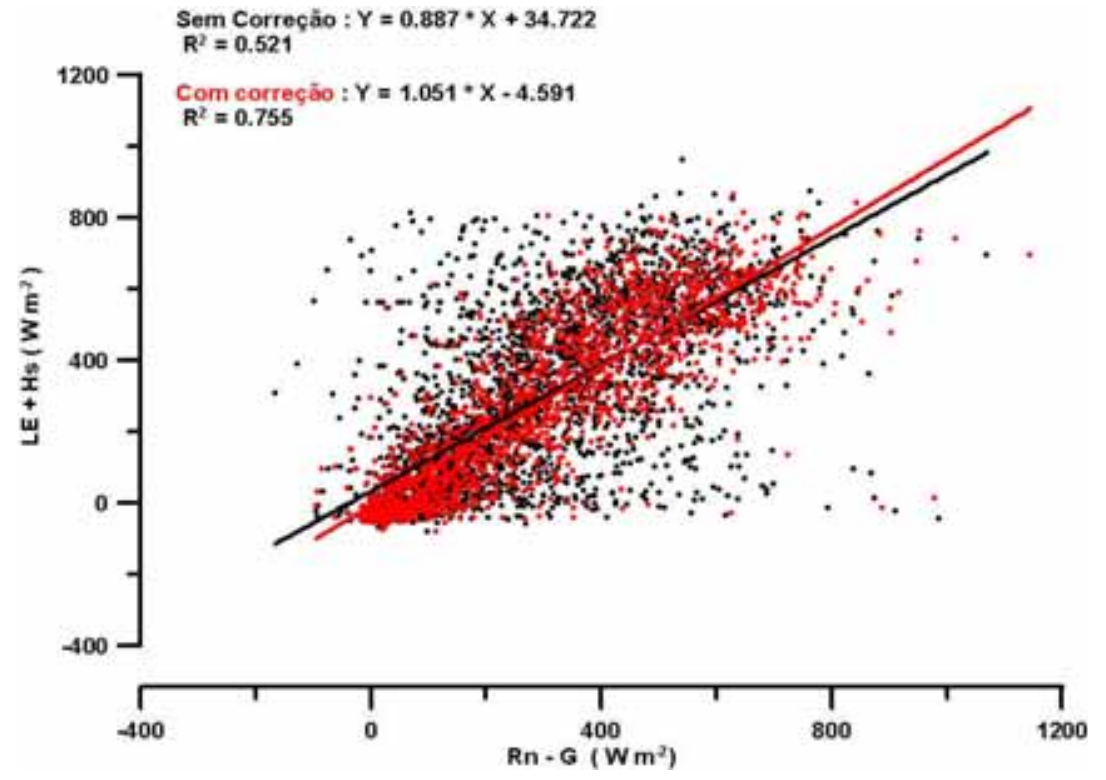

Figura 38 - Fechamento do balanço de energia para o sítio do ecótono Floresta-Cerrado, para o período de feveiro de 2004 a junho de 2004. Período de alagamento. Os pontos pretos eferem-se aos fluxos sem correções. Os pontos vermelhos vermelhos referem-se aos fluxos com a correção de Riehl e Webb 


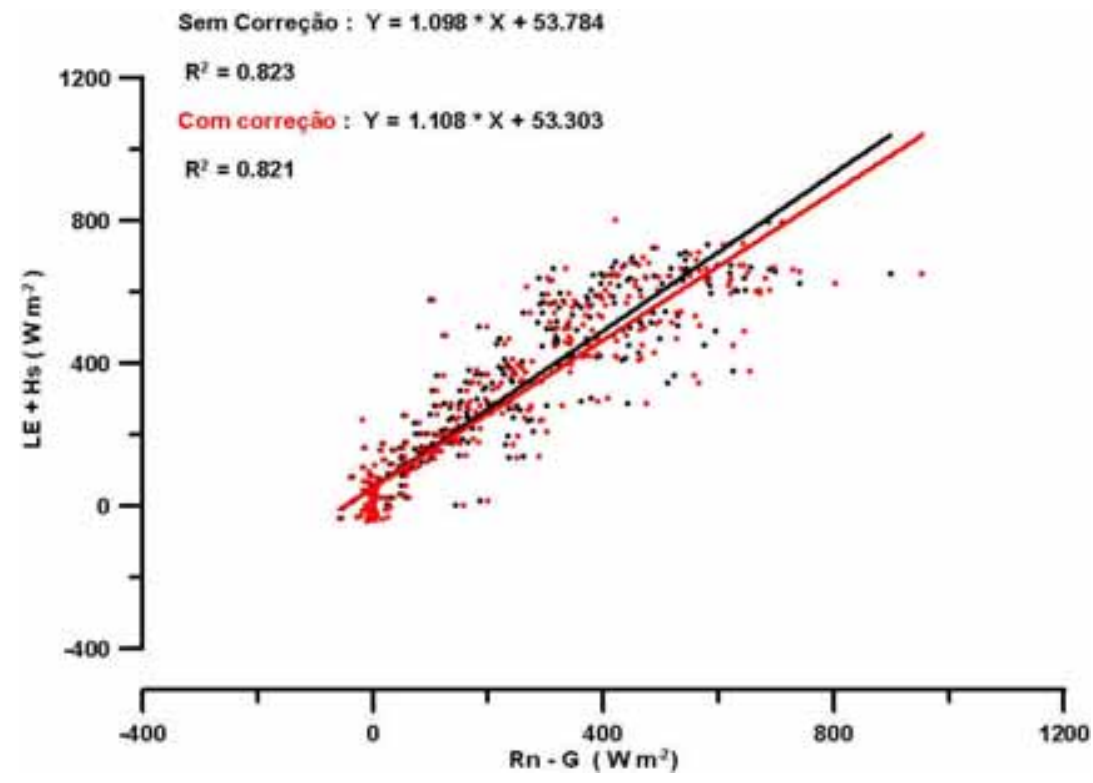

Figura 39 - Fechamento do balanço de energia para o sítio do ecótono Floresta-Cerrado, para o período de julho de 2004 a setembro de 2004. Os pontos pretos eferem-se aos fluxos sem correções. Os pontos vermelhos vermelhos referem-se aos fluxos com a correção de Riehl e Webb 


\section{APÊNDICE 3 - Comparação dos sensores de radiação do Cerrado S.S.}

Os piranômetros (sensores de radiação solar global) foram calibrados (Juarez, 2004). A somatória acumulada dos sensores de radiação global e radiação PAR pode testar de forma indireta a qualidade dos resultados obtidos pelo sensor de radiação PAR. As Figuras 40 e 41 mostram que não foi levantado nenhum problema de deriva de algum dos sensores.

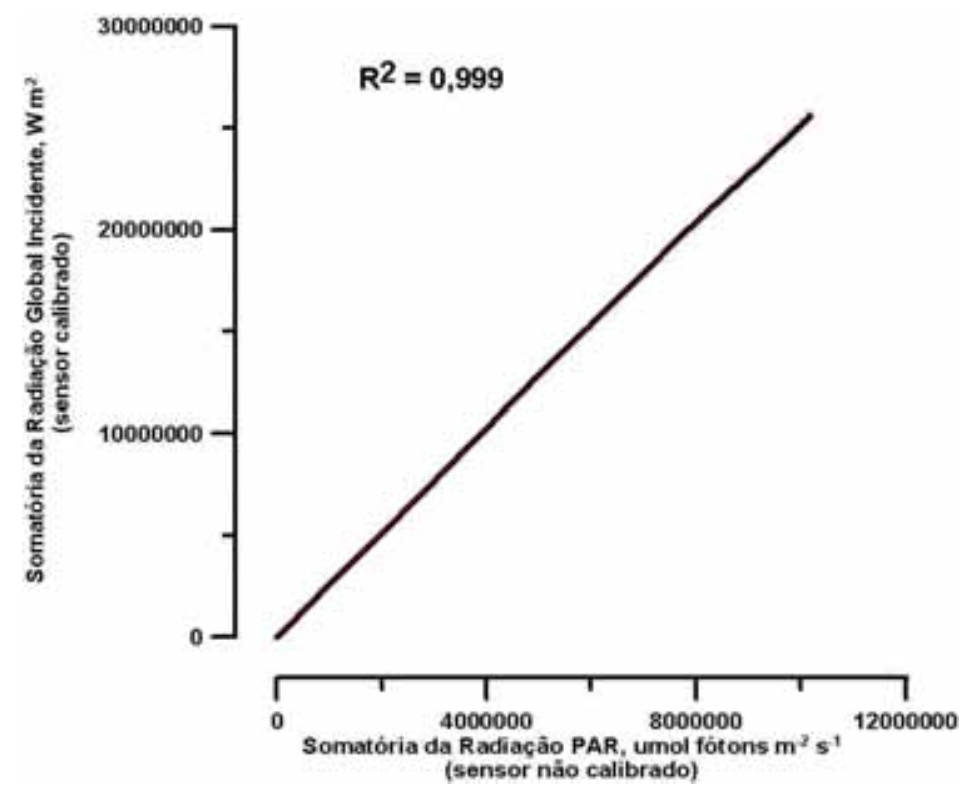

Figura 40 - Somatória, dos anos de 2001 a 2003, dos valores de radiação incidente obtidos pelo piranômetro (calibrado), em $\mathrm{Wm}^{-2}$, contra somatória do sensor

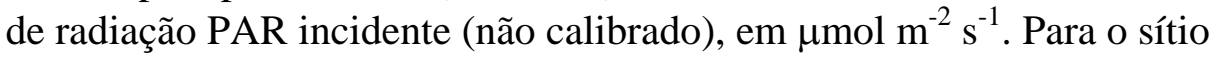
experimental do Cerrado 


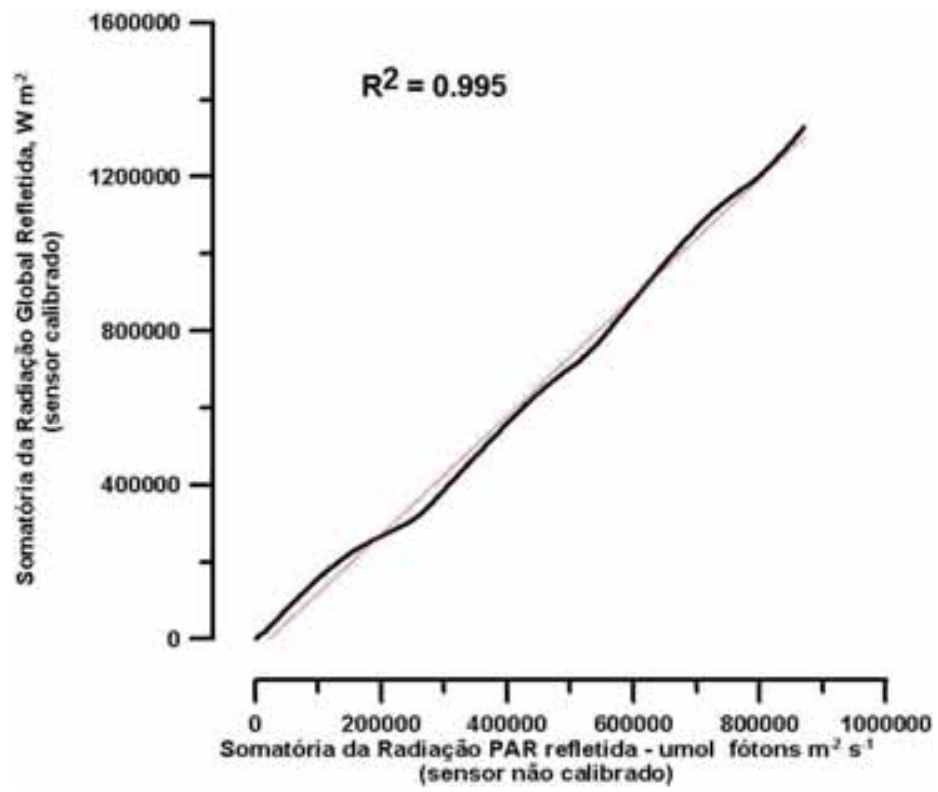

Figura 41 - Somatória, dos anos de 2001 a 2003, dos valores de radiação refletida obtidos pelo piranômetro (calibrado), em $\mathrm{Wm}^{-2}$, contra somatória do sensor

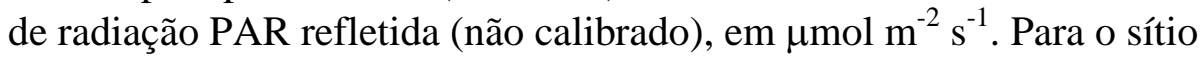
experimental do Cerrado 


\section{APÊNDICE 4 - Velocidade de atrito e direção do vento}

A velocidade de atrito ( $\mathrm{u}^{*}$ ) apresentou uma acentuada dimimuição com o fim do período chuvoso (Figura 42). Logo após a inundação, houve uma acentuada diminuição, até o início de um novo período de chuvas.

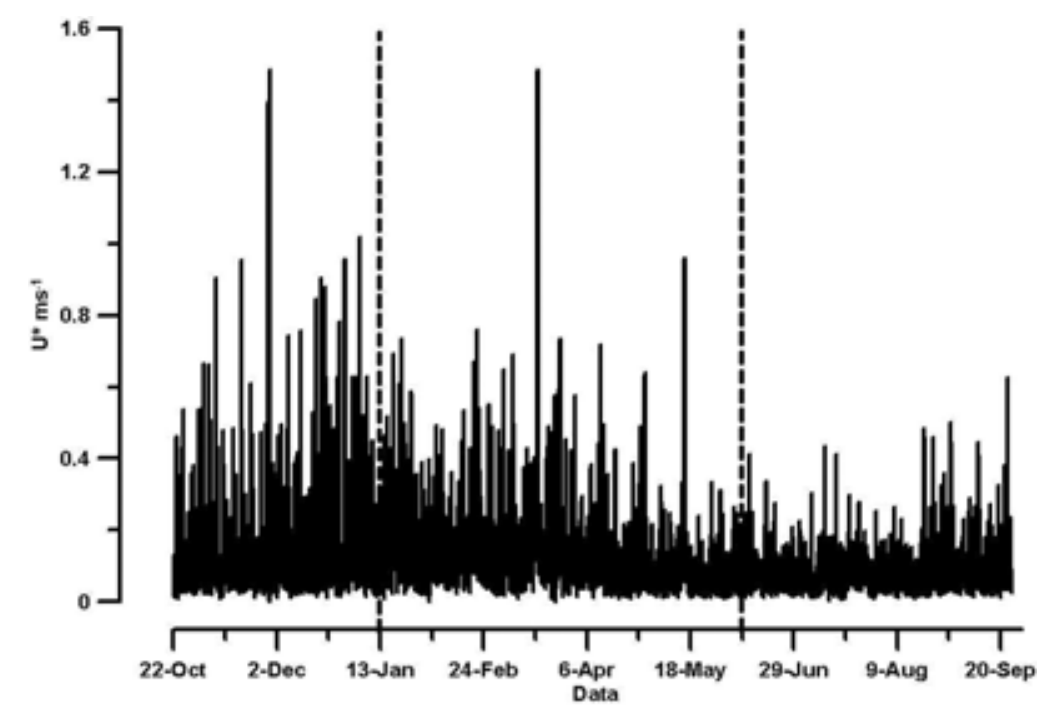

Figura 42 - Velocidade de atrito para o sítio experimental do ecótono Floresta-Cerrado. As barras verticais segmentadas, indicam início e fim aproximado da inundação, respectivamente.

Para o sítio do Cerrado s.s. as máximas foram bastante semelhantes entre 2001 e 2002, sendo que o ano de 2002 apresentou valores mínimos e máximos um pouco maiores, não apresentando diferença na sazonalidade do $\mathrm{u}^{*}$ (Juarez, 2004). No sítio experimental do Cerrado s.s., o vento apresentou, predominantemente, a direção leste, tanto de dia quanto de noite (Juarez, 2004). Na área do ecótono a direção média mostrou-se de Norte como preferencial para o vento noturno de Oeste e Norte no período diurno (Fig. 43). 

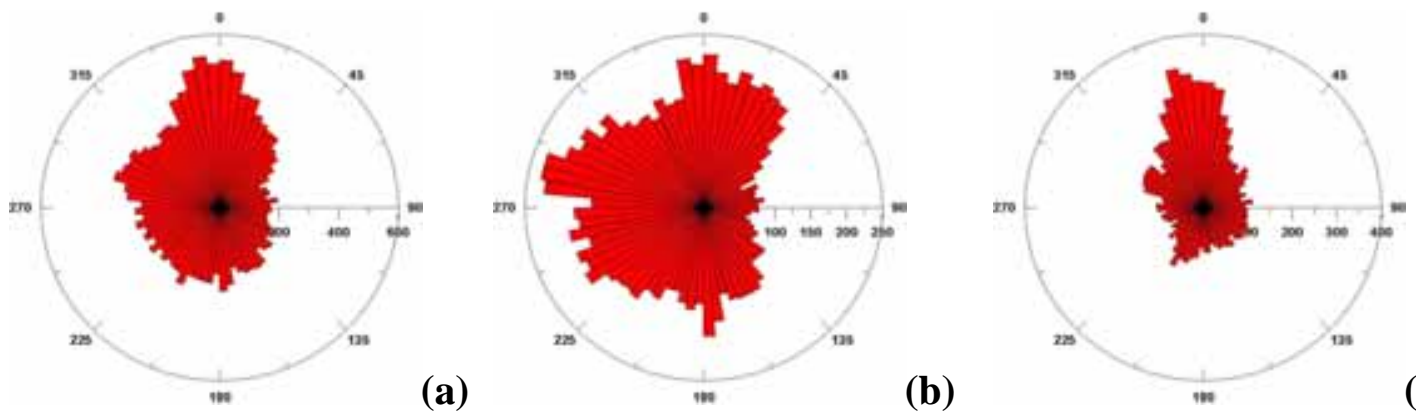

(c)

Figura 43 - Anemogramas do ecótono Floresta-Cerrado. Para todo o período de outubro de 2003 a setembro de 2004. Anemograma de direção do vento (a) média diária, (b) diurno e (c) noturno. A direção do vento só foi contabilizada pra valores do módulo acima de $2 \mathrm{~m} \mathrm{~s}^{-1}$. O Norte está a $0^{\circ}$. 